\title{
Mangrove-Associated Fungi: A Novel Source of Potential Anticancer Compounds
}

\author{
Sunil K. Deshmukh ${ }^{1, *(\mathbb{B})}$, Manish K. Gupta ${ }^{1}$ (i), Ved Prakash ${ }^{2}$ (1) and M. Sudhakara Reddy ${ }^{3}$ \\ 1 TERI-Deakin Nano Biotechnology Centre, The Energy and Resources Institute (TERI), Darbari Seth Block, \\ IHC Complex, Lodhi Road, New Delhi 110003, India; manish.gupta@teri.res.in \\ 2 Department of Biotechnology, Motilal Nehru National Institute of Technology, Allahabad 211004, India; \\ ved.mits@gmail.com \\ 3 Department of Biotechnology, Thapar Institute of Engineering \& Technology, Patiala, Punjab 147004, India; \\ msreddy@thapar.edu \\ * Correspondence: sunil.deshmukh@teri.res.in or sunil.deshmukh1958@gmail.com
}

Received: 16 July 2018; Accepted: 21 August 2018; Published: 24 August 2018

\begin{abstract}
Cancer is the second leading cause of death worldwide, and the number of cases is increasing alarmingly every year. Current research focuses on the development of novel chemotherapeutic drugs derived from natural as well as synthetic sources. The abundance and diversity in natural resources offer tremendous potential for the discovery of novel molecules with unique mechanisms for cancer therapy. Mangrove-derived fungi are rich source of novel metabolites, comprising novel structure classes with diverse biological activities. Across the globe, coastal areas are primarily dominated by mangrove forests, which offer an intensely complex environment and species that mostly remain unexplored. In recent years, many structurally diverse compounds with unique skeletons have been identified from mangrove fungi and evaluated for their antiproliferative properties. These compounds may serve as lead molecules for the development of new anticancer drugs. Mangrove endophytes can be modulated using epigenetic means or culture optimization methods to improve the yield or to produce various similar analogs. The present review provides an insight into the bioactive metabolites from mangrove endophytes reported during the period from 2012 to 2018 (up to April, 2018) along with their cytotoxic properties, focusing on their chemical structures and mode of action, as indicated in the literature.
\end{abstract}

Keywords: endophytic fungi; anticancer compounds; mangroves; co-culture; epigenetic modification

\section{Introduction}

Mangroves are salt-tolerant forest ecosystems, representing a lively ecosystem with an amalgam of land-dwelling and marine habitats with high biodiversity and socio-economic importance [1]. Marine fungi are among the most prominent species existing in mangrove forests, and support nutrient replenishment [2]. As per reports on marine fungi, in this ecological niche mangrove fungi make up the second largest group [3]. These fungi may occur as saprophytes, symbiotically or as a parasites in the mangrove ecosystem. In addition, these fungi belong to both the lower class, such as oomycetes and thraustochytrids, and the upper class, such as ascomycetes and basidiomycetes. Fungal secondary metabolites are structurally quite diverse, and their functions mostly depend on self-defense against other microorganisms [4]. Most often mangrove fungi flourish in challenging habitats, making them a rich source of bioactive metabolites. Endophytes are one of the various groups of mangrove fungi that have resulted in the identification of a large number of new bioactive metabolites of nutraceutical and pharmaceutical importance. These include antibiotic, anticancer, antidiabetic, antioxidant, antiviral, anti-inflammatory and immunosuppressive drugs, along with other pharmaceutical agents [5]. 
Cancer affects different organs, and is identified by the unchecked proliferation of abnormal cells that invade other healthy tissue. The treatment is primarily confined to chemotherapy. Besides being expensive, chemotherapy is known to cause severe side effects, making treatment problematic. The non-effectiveness of many existing drugs along with multi-drug resistance further aggravates the problem, making cancer treatment difficult. For medicinal chemists, the primary goal remains the discovery and identification of chemotherapeutic agents derived from natural products. Secondary metabolites have opened new avenues for the development of novel therapeutic agents $[6,7]$. Endophytic fungi, which are a less-explored area of the microbial community, have a tremendous potential to produce new metabolites that can be used for pharmaceutical applications. Since the initial report of the identification of paclitaxel, derived from an endophyte associated with Northwest Pacific yew by Stierle et al. [8], scientists have identified many other crucial anticancer molecules from fungal endophytes [6]. Many researchers were attracted to marine mangrove fungi because of their diversity, which may lead to the discovery of several novel natural products. With the remarkable advancements in spectroscopic techniques, separation methods and microplate-based sensitive in vitro assays, the natural product exploration of mangrove fungi has attracted special attention regarding novel and unexplored chemical scaffolds [9]. Of the various existing groups of mangrove fungi, endophytes have been identified as producers of new bioactive metabolites with pharmaceutical and nutraceutical importance.

Most of the endophytes have the potential to produce novel bioactive metabolites, which will undoubtedly boost novel drug discovery. However, higher similarity among microbes leads to the frequent identification of the same compound in the endophytes. During axenic cultivation, a specific portion of the biosynthetic genes are expressed while growing in vitro, and various genes stay masked or silent and do not express in laboratory conditions. For this reason, the routine method of fermentation yields metabolites without chemical diversity. Co-cultivation could help to overcome this problem and is preferred, with two or more microbes allowed to grow together. This approach offers a better competitive environment, allowing the increased production of constitutive as well as cryptic compounds that are not traced out in axenic cultures [10]. Several co-cultivation strategies such as different combinations of fungi, the co-cultivation of fungi with bacteria and the co-cultivation of different bacteria have been reported for the enhancement of the chemical diversity of marine-derived microorganisms [10].

The development of methodologies to induce the expression of biosynthetic transcription as well as the suppression of these genes plays a vital role in the search for new secondary metabolites. The regulation of the enzymes that control metabolite production can be achieved by changing epigenetic mechanisms such as DNA methylation and histone modifications (acetylation and phosphorylation) by using epigenetic modifiers [11]. As an example of the importance of epigenetic modulation in producing unknown natural products, when Aspergillus niger is cultivated over a two-week period in vermiculite-based semi-solid medium treated with suberoylanilide hydoxamic acid (SAHA), it leads to the isolation of a new fungal metabolite nygerone [12]. Hence the epigenetic approach can be a game changer in the production/enhancement of secondary metabolites.

The present review provides a comprehensive overview of the bioactive metabolites identified from mangrove endophytes during the period from 2012 to 2018 (up to April, 2018) including eighty novel compounds of the total 181 reported. The total number of compounds as well as novel compounds isolated from mangrove fungi during this period is presented in Figure 1. The origin, chemical structure of the biological targets and efficacies of these compounds are also discussed where available. The anticancer properties of many of these compounds are presented in Table 1. They are arranged based on the broader category of the taxonomic class of the cytotoxic compounds producing fungi. An attempt has also been made to review recent developments such as co-cultivation and epigenetic modifications in endophytic fungi to enhance the secondary metabolite production. 


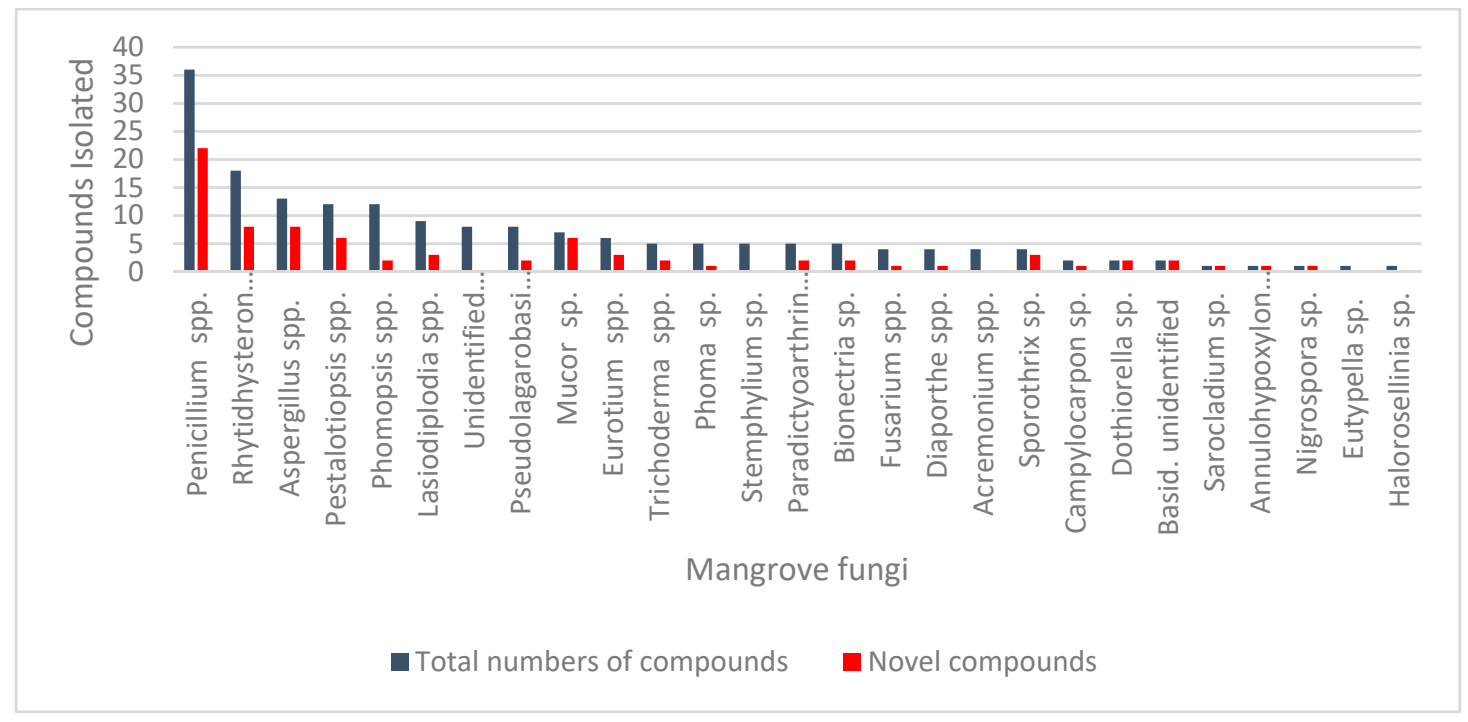

Figure 1. Novel anticancer bioactive compounds reported from mangrove fungi.

\section{Bioactive Compounds in Mangrove Plants}

\subsection{Compounds Produced by Coelomycetes}

Pestalotiopsis is the most noteworthy coelomycetous fungi and the species of Pestalotiopsis are known to produce the diverse array of novel compounds. Strobel and Long [13] described Pestalotiopsis as the "E. coli of the temperate and tropical rainforest systems". The species Pestalotiopsis is widely recognized to be a prolific producer of a diverse array of metabolites that include alkaloids, chromones, coumarins, isocoumarin derivatives, lactones, peptides, phenols, phenolic acids, quinones, semiquinones, xanthones, terpenoids and xanthone derivatives along with an array of antimicrobial, antifungal, antitumor, antiviral, antineoplastic, and antioxidant compounds [14,15]. Some of the cytotoxic compounds reported from this genus such as demethylincisterol A3 (1), ergosta-5,7,22-trien-3-ol (2), stigmastan-3-one (3), stigmast-4-en-3-one (4), stigmast4-en-6-ol-3-one (5), and flufuran (6) (Figure 2), were discovered from Pestalotiopsis spp., associated with Chinese mangrove Rhizophora mucronata. Compounds 2-6 showed cytotoxicity against human cancer cell lines HeLa, A549, and HepG, with $\mathrm{IC}_{50}$ values in the range of 11.44-102.11 $\mu \mathrm{M}$. Compound 1 had the most potential, with $\mathrm{IC}_{50}$ values reaching the $\mathrm{nM}$ activity level from 0.17 to $14.16 \mathrm{nM}$. Flow cytometric investigation demonstrated that compound 1 inhibited the cell cycle at the G0/G1 phase in a dose-dependent manner with a significant induction of apoptosis on the three tested cell lines. The involvement of the mitochondria in compound-1-induced apoptosis was demonstrated using MMP [16].

The compounds 7-O-methylnigrosporolide (7), pestalotioprolides D-F (8, 9, 10) (Figure 2), were extracted from the Pestalotiopsis microspora, endophytic fungus obtained from the fruits of Drepanocarpus lunatus collected from Douala, Cameroon. An approximately ten-fold increase in the yield of compounds $\mathbf{9}$ and $\mathbf{1 0}$ compared to axenic fungal control was observed when P. microspora was co-cultured with Streptomyces lividans. Compounds 7-10 exhibited cytotoxicity against the L5178Y cell line with $\mathrm{IC}_{50}$ values of $0.7,5.6,3.4$, and $3.9 \mu \mathrm{M}$, respectively, and compound 9 also showed potent activity against the $\mathrm{A} 2780$ cell line displaying an $\mathrm{IC}_{50}$ value of $1.2 \mu \mathrm{M}$ [17].

Another study by Hemphill et al. reported a new compound pestalpolyol I (11) (Figure 2) of the polyketide group from Pestalotiopsis clavispora, the endophytic fungus obtained from petioles of the Rhizophora harrisonii, growing in Port Harcourt (Nigeria). Compound $\mathbf{1 1}$ showed cytotoxicity against the L5178Y cell line with an $\mathrm{IC}_{50}$ value of $4.10 \mu \mathrm{M}$ [18].

A new aromatic amine, pestalamine A (12) (Figure 2), was isolated from P. vaccinia from a branch of Kandelia candel, a viviparous mangrove species widely distributed in coastal and estuarine areas 
of southern China. The structure of pestalamine A 12 was determined by spectroscopic methods, especially 2D NMR analyses. Compound 12 showed moderate cytotoxicity against MCF-7, HeLa, and HepG2 human cancer cell lines with $\mathrm{IC}_{50}$ values of $40.3,22.0$, and $32.8 \mu \mathrm{M}$, respectively [19].

Phomazines B (13), epicorazine A (14), epicorazine B (15), epicorazine C (16), exserohilone A (17) (Figure 2), were isolated from an endophytic fungus, Phoma sp. OUCMDZ-1847 associated with the fruit of Kandelia candel collected in Wenchang, Hainan Province, China. Compounds 13-17 showed cytotoxicity against the HL-60, HCT-116, K562, MGC-803, and A549 cell lines with IC 50 values in the range of 0.05 to $8.5 \mu \mathrm{M}[20]$.

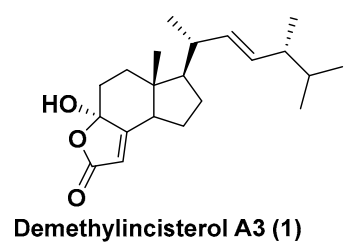<smiles>CC(C)CCCC(C)C1CCC2C3CCC4=CC(=O)CCC4CC3CC12</smiles>

Stigmast-4-en-3-one (4)<smiles>CO/C=C\C/C=C/C(=O)OC(C)CC(C)C</smiles>

7-O-Methylnigrosporolide (7)

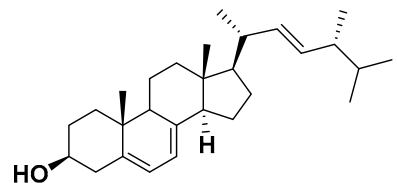

Ergosta-5,7,22-trien-3-ol (2)

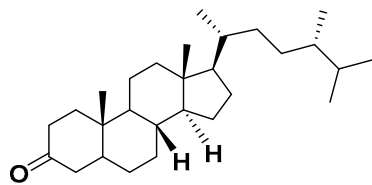

Stigmastan-3-one (3)

HOOC<smiles>CC(C)CCCC1CCC2C3CC(O)C4CC(=O)CCC4(C)C3CCC12C</smiles>

stigmast4-en-6-ol-3-one (5)

Flufuran (6)<smiles>CCC(=O)CCC(=O)OC(C)CC/C=C\OC</smiles>

Pestalotioprolides D (8)

$\mathrm{R}=\alpha-\mathrm{OH}:$ Pestalotioprolide E (9)

$\mathbf{R}=\beta-\mathrm{OH}$ : Pestalotioprolide F (10)<smiles>CC[C@H](C)C[C@H](/C=C(\C)[C@@H](O)[C@@H](C)/C=C(\C)[C@@H](O)[C@@H](C)/C=C/[C@@H](O)[C@@H](C)/C=C(\C)C=O)CO</smiles>

Pestalpolyol I (11)<smiles>CS[C@]1(Cc2ccccc2)NC(=O)[C@@]2(SC)CC3=CC=C[C@H](O)C3(C)N2C1=O</smiles>

Phomazines B (13)

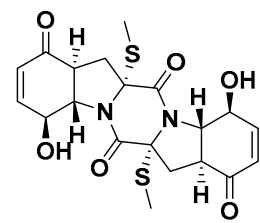

Exserohilone A (17)

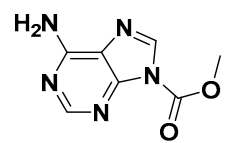

6-Aminopurine-9-carboxylic acid methyl ester (20)

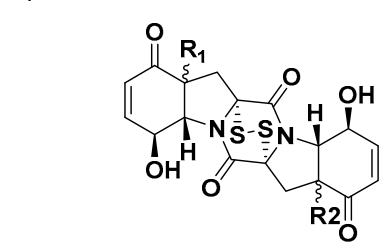

$\mathbf{R}_{\mathbf{1}}=\mathbf{R}_{\mathbf{2}}=\alpha-\mathbf{H}:$ : Epicorazine A (14) $\mathbf{R}_{\mathbf{1}}=\alpha-\mathbf{H}, \mathbf{R}_{\mathbf{2}}=\beta-\mathrm{H}:$ Epicorazine $\mathrm{B}(15)$

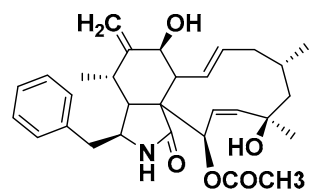

Cytochalasin $\mathrm{H}$ (18)

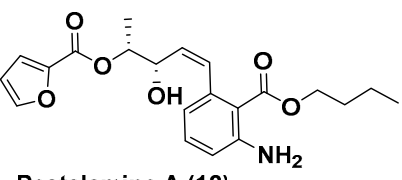

Pestalamine A (12)

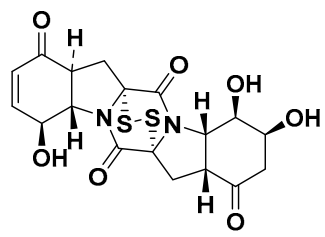

Epicorazine C (16)

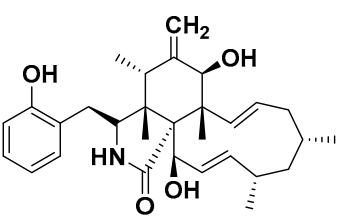

Phomopsichalasin G (19)

$$
0
$$

Uridine (21)

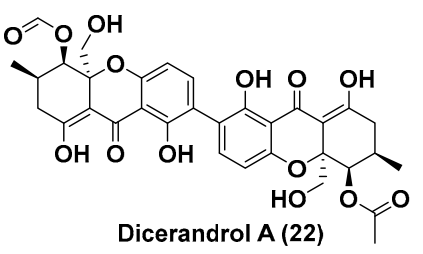

Figure 2. Structures of metabolites isolated from Coelomycetes (1-22). 
Cytochalasin H (18) (Figure 2), was identified form Phomopsis sp., an endophytic fungus of mangrove origin in Zhanjiang, China. Compound 18 was shown to inhibit the cell cycle of A549 cells at the G2/M phase. Additionally, DNA fragmentation along with a decrease in the transmembrane potential of mitochondria was observed in A549 cells. It was also shown to regulate the expression level of Bax, P53, Bcl-xL, and Bcl-2. On treatment with Cytochalasin $\mathrm{H}$, the migration capability was impaired in a dose-dependent manner [21].

A new cytochalasin, phomopsichalasin G (19) (Figure 2), was isolated from Phomopsis sp. xy21, and xy22, associated with Xylocarpus granatum, collected in Trang Province, Thailand. Compound 19 exhibited inhibitory activities against HCT-8, HCT-8/T, A549, MDA-MB-231, and A2780 cancer cell lines with $\mathrm{IC}_{50}$ values of $7.5,8.6,6.4,3.4$, and $7.1 \mu \mathrm{M}$, respectively [22].

6-Aminopurine-9-carboxylic acid methyl ester (20) and uridine (21) (Figure 2), were isolated from Phomopsis longicolla HL-2232, an endophyte of Bruguiera sexangula var. rhynchopetala. The compounds 20 and 21 exhibited cytotoxicity against MCF-7 and A549 cell lines with $\mathrm{IC}_{50}$ values of 14.9 and $8.6 \mu \mathrm{M}$, respectively [23].

Phomopsis sp. HNY29-2B, an endophyte isolated from the branch of Acanthus llicifolius collected from the South China Sea in Hainan province, China, is reported as a source of the known phomoxanthones, including dicerandrol A (22) (Figure 2), dicerandrol B (23), dicerandrol C (24), diacetylphomoxanthone B (25) and penexanthone A (26) (Figure 3). Compound 22 exhibited broad-spectrum cytotoxic activity against MDA-MB-435, HCT-116, Calu-3 and Huh7 cell lines with $\mathrm{IC}_{50}$ values of 3.03, 2.64, 1.76 and $4.19 \mu \mathrm{M}$, respectively. Compound 23 and 26 showed potent cytotoxic activities against MDA-MB-435, HCT-116, and Calu-3 $\left(\mathrm{IC}_{50}<10 \mu \mathrm{M}\right)$, and displayed poor cytotoxic activity effects against the MCF-10A cell line ( $\left.\mathrm{IC}_{50}>50 \mu \mathrm{M}\right)$. Compound 24 exhibited cytotoxic activity against the MDA-MB-435, HCT-116, Calu-3, MCF-10A cell lines with $\mathrm{IC}_{50}$ values of 44.10, 42.63, 36.52, and $33.05 \mu \mathrm{M}$, respectively. Compound 25 exhibited cytotoxicity against the MDA-MB-435, HCT-116, Calu-3, Huh7 cell lines with $\mathrm{IC}_{50}$ values of $14.40,7.12,4.14$ and $29.20 \mu \mathrm{M}$ and showed no cytotoxic effect on the MCF-10A cell line [24].

A new xanthone $O$-glycoside, 3-O-(6-O- $\alpha$-L-arabinopyranosyl)- $\beta$-D-glucopyranosyl-1,4dimethoxyxanthone (27) (Figure 3), was isolated from an endophytic fungus, Phomopsis sp. (ZH76) obtained from the stem of Excoecaria agallocha of a mangrove from Dong Sai on the South China Sea coast. Compound 27 had an inhibitory effect on the growth of HEp-2 and HepG2 cells displaying $\mathrm{IC}_{50}$ values of 9 and $16 \mu \mathrm{M}$, respectively [25].

A highly oxygenated chloroazaphilone derivative, isochromophilone D (28), and a known analogue epi-Isochromophilone II (29) (Figure 3), were isolated from Diaporthe sp. SCSIO 41011, the endophytic fungus associated with Rhizophora stylosa, collected in Sanya city, Hainan Province, China. Compound 29 exhibited cytotoxic activity against the ACHN, OS-RC-2, and 786-O cell lines with $\mathrm{IC}_{50}$ values ranging from 3.0 to $4.4 \mu \mathrm{M}$. Sorafenib, a positive control, exhibited cytotoxic activity against the tested cell lines with $\mathrm{IC}_{50}$ in the range of 3.4 to $7.0 \mu \mathrm{M}$. Compound 28 showed activity against 786-O cells with an $\mathrm{IC}_{50}$ of $8.9 \mu \mathrm{M}$. In a dose- and time-dependent manner, apoptosis was induced in 786-O cells by compound 28 [26].

New chromeno[3,2-c] pyridine, 5-deoxybostrycoidin (30), and fusaristatin A (31) (Figure 3), were isolated from an endophytic fungus Diaporthe phaseolorum SKS019 isolated from the branches of the mangrove plant Acanthus ilicifolius, collected from Shankou in Guangxi province, China. Compound 30 exhibited cytotoxicity against the MDA-MB-435, and NCI-H460 human cancer cell lines with $\mathrm{IC}_{50}$ values of 5.32 and $6.57 \mu \mathrm{M}$, respectively, and compound 31 showed growth-inhibitory activity against the MDA-MB-435 human cancer cell line with an $\mathrm{IC}_{50}$ value of $8.15 \mu \mathrm{M}$ [27].

Mycoepoxydiene (32) and deacetylmycoepoxydiene (33) (Figure 3) were isolated from a mangrove endophytic fungus Phomosis sp. A818 isolated from the foliage of Kandelia candel, collected from the Mangrove Nature Conservation Area of Fugong, Fujian Province, China. Compounds 32 and 33 had $\mathrm{IC}_{50}$ values of 7.85 and $14.61 \mu \mathrm{M}$, respectively, against MDA-MB-435 [28]. Mycoepoxydiene (32) (Figure 3), significantly suppressed antigen-stimulated degranulation and cytokine production in 
mast cells and IgE-mediated passive cutaneous anaphylaxis in mice. Compound 32 suppressed antigen-induced activation of Syk, and subsequently inhibited the phosphorylation of PLC $\gamma 1$, Akt, and MAPKs such as extracellular signal-regulated kinase, c-jun N-terminal kinase, and p38 in mast cells. Mycoepoxydiene can inhibit the activation of mast cells and protect mice from a mast-cell-mediated allergic response through inhibiting the activation of Syk [29].

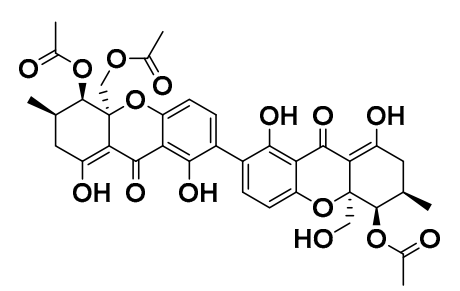

Dicerandrol B (23)

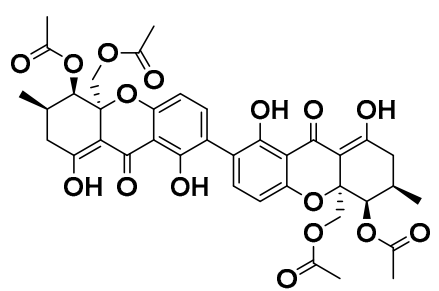

Dicerandrol C (24)

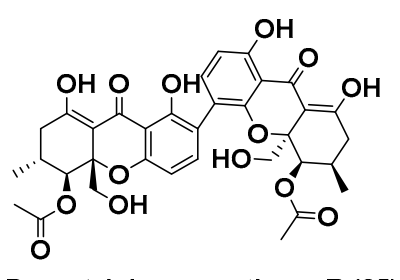

Deacetylphomoxanthone B (25)

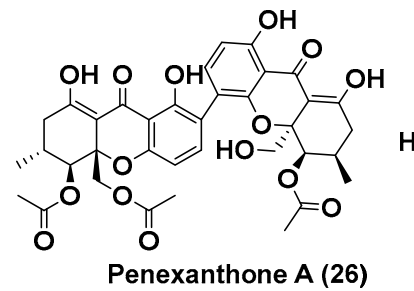

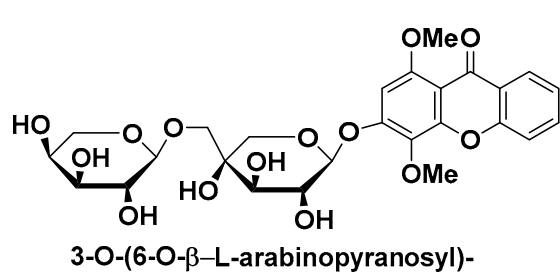

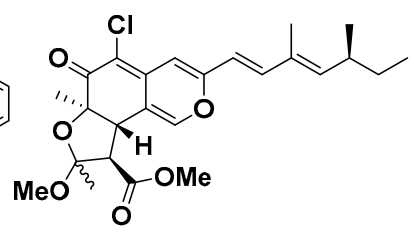
3-O-(6-O- $\beta$-L-arabinopyranosyl)$\beta$-D-glucopyranosyl-1,4 -dimethoxyxanthone (27)<smiles>CCC(C)/C=C(C)/C=C/C1=CC2=C(Cl)C(=O)C(C)(O)[C@H](C(C)=O)C2=CO1</smiles>

epi-Isochromophilone II (29)<smiles>COc1cc(O)c2c(c1)C(=O)c1cnc(C)cc1C2=O</smiles>

5-Deoxybostrycoidin (30)

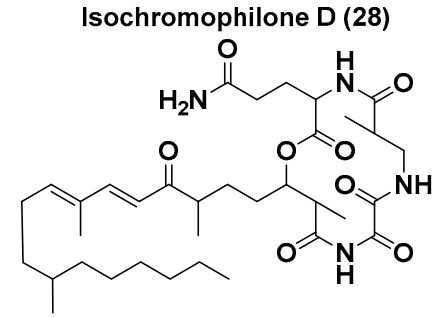

Fusaristatin A (31)<smiles>CC1C2OC(=O)C=CC2CC12OC(=O)C=CC2O</smiles>

$\mathrm{R}=\mathrm{Ac}:$ Mycoepoxydiene (32)<smiles>COC(=O)[C@@]1(Cc2ccc(OCC=C(C)C)cc2)NC(=O)[C@H](SC)N(C)C1=O</smiles><smiles></smiles>

$\mathrm{R}=\mathrm{H}$ : Deacetylmycoepoxydiene (33)<smiles>Cc1cc(O)c2c(c1)[C@H](O)[C@@H]1C=C[C@@H](O)[C@@H](O)[C@H]1C2=O</smiles><smiles>CC1=CCC[C@H]2C=C3OC(=O)C(CO)=C3C[C@H]12</smiles>

Saroclazine B (34)<smiles>O=C1OC2OC1C1=CCCC3(O2)c2cccc4cccc(c24)OC13</smiles>

Daldinone I (35)<smiles>O=C1C2=CCCC3(COCC1O3)Oc1cccc3cccc2c13</smiles>

Rubrumol (36)<smiles>[R]c1ccc(O)c2c1O[C@]1(CCC(=O)c3cccc4cccc1c34)O2</smiles>

$\mathrm{R}=\mathrm{H}$ : Deoxypreussomerin $\mathrm{B}(40)$ $\mathrm{R}=\mathrm{OH}$ : Palmarumycin CP17 (41)<smiles></smiles>

Preussomerin EG4 (43) Rhytidenone E (44)
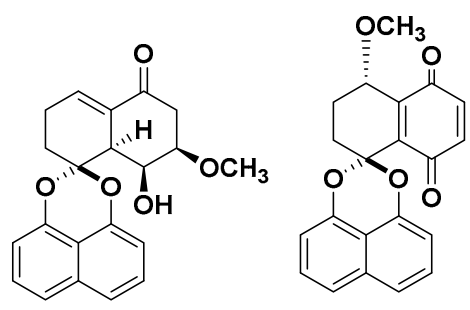

Palmarumycin C (46)

Figure 3. Structures of metabolites isolated from Coelomycetes (23-33) and Ascomycetes (34-46). 


\subsection{Compounds Produced by Ascomycetes}

A new diketopiperazine derivative, saroclazine B (34) (Figure 3), was isolated from the mangrove-derived fungus Sarocladium kiliense HDN11-84 isolated from the rhizosphere soil of the mangrove plant Thespesia populnea, collected in Guangxi Province, China. Compound 34 showed cytotoxicity against HeLa cell lines with an $\mathrm{IC}_{50}$ value of $4.2 \mu \mathrm{M}$ [30].

Benzofluoranthene metabolites and daldinone I (35) (Figure 3) were extracted from Annulohypoxylon sp., an endophytic fungus associated with Rhizophora racemose, collected in Cameroon. Compound 35 exhibited average to potent cytotoxicity with $\mathrm{IC}_{50}$ values of 14.1 and $6.6 \mu \mathrm{M}$, against Jurkat J16 and Ramos cell lines, respectively. It was reported that compound 35 induces apoptotic cell death caused by the induction of intrinsic apoptosis [31].

A new anthraquinone rubrumol (36) (Figure 3) with poly-hydroxyl groups was isolated from a halo-tolerant endophytic fungus Eurotium rubrum, isolated from the salt-tolerant wild plant Suaeda salsa L. collected from the "BoHai" seaside, China. The biological effect of compound 36 on Topo I to relax supercoiled pBR322 DNA was investigated in the cleavable complex assay. The results indicated that compound 36 displayed biological activity compared to the positive control camptothecin. The relaxation activity of rubrumol (36) was stronger than that of camptothecin at the concentration of $100 \mu \mathrm{M}$. The band backward shifting and trailing of rubrumol (36) was observed at 100, 50, 10, 5 and $1 \mu \mathrm{M}$. Compound 36 also exhibited cytotoxic activities against A549, MDA-MB-231, PANC-1 and HepG2 human cancer cell lines, by MTT method. The inhibition rate for compound 36 against these four cancer cell line was less than $60 \%$ at $100 \mu \mathrm{g} / \mathrm{mL}$, which implied that it displayed no significant cytotoxic activity [32].

The 13-Hydroxy-3,8,7(11)-eudesmatrien-12, 8-olide (37) (Figure 3) was isolated from Eutypella sp. 1-15 isolated from the soil of the mangrove rhizosphere in Jimei, Fujian Province, China. Compound 37 exhibited potent anticancer activity against JEKO-1 and HepG2 with $\mathrm{IC}_{50}$ values of 8.4 and 28.5 $\mathrm{Mm}$, respectively [33].

Rhytidenones G (38), H (39), deoxypreussomerin B (40), palmarumycin CP17 (41), 1-oxo-1,4dihydronapthalene-4-spiro-20-naptho[400-hydroxy-100,800-de][10,30]-dioxine (42), preussomerin EG4 (43), rhytidenone E (44), rhytidenone F (45), palmarumycin C5 (46), (Figure 3), and 4,8-dihydroxy3,4-dihydronaphthalen-1(2H)-one (47) (Figure 4), were isolated from Rhytidhysteron rufulum AS21B, an endophytic fungus associated with the leaves of Azima sarmentosa, collected from the mangrove forest in Samutsakhon province, Thailand. The culture in acidic medium enhanced the production of compounds 41 and 45, with a four-fold and eight-fold increase, respectively, which are present in minor quantities under normal culture condition. Compounds 38-47 exhibited cytotoxicity against Ramos cells with $\mathrm{IC}_{50}$ values of $17.98,0.018,18.00,33.1,15,82.9,0.461,0.048,31.7$ and $23.1 \mu \mathrm{M}$, respectively, while the control Ibrutinib exhibited cytotocity of $28.7 \mu \mathrm{M}$ against the same cell line. Compounds 38-39, 44-45, and 47 exhibited cytotoxicity against the $\mathrm{H} 1975$ cell lines with an $\mathrm{IC}_{50}$ value of 7.3, 0.252, $10.24,1.17$ and $50 \mu \mathrm{M}$, respectively, while control afatinib exhibited cytotoxicity of $1.97 \mu \mathrm{M}$ against the same cell line [34].

Lasiodiplodia sp. 318\#, an endophytic fungus associated with Excoecaria agallocha, collected from Guangdong Province, China, was the source of compound 2,4-Dihydroxy-6-nonylbenzoate (48) (Figure 4). Compound 48 exhibited cytotoxicity against the MMQ and GH3 cell lines with $\mathrm{IC}_{50}$ values of 5.2 and $13.0 \mu \mathrm{M}$, respectively [35]. Previously, a new lasiodiplodin-ethyl-2,4dihydroxy-6-(8'-hydroxynonyl)-benzoate (49)—was obtained from the same fungus. Compound 49 exhibited average cytotoxicity against the MDA-MB-435, HepG2, HCT-116, A549, and leukaemia THP1 cell lines with $\mathrm{IC}_{50}$ values of $10.13,12.50,11.92,13.31$ and $39.74 \mu \mathrm{M}$, respectively [36]. 
<smiles>O=C1CC[C@H](O)c2cccc(O)c21</smiles>

4,8-Dihydroxy-3,4 -dihydronaphthalen $-1(2 \mathrm{H})$-one (47)<smiles>[R]C1[C@H](Cl)C(=O)c2c(O)ccc3c2[C@@]12Oc1cccc4c1[C@@](O3)(O4)[C@H](OC)CC2=O</smiles>

$\mathrm{R}=\mathrm{OH}:$ Chloropreussomerin A (50) $\mathbf{R}=\mathrm{OMe}$ :Chloropreussomerin B (51)

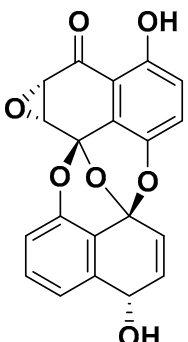<smiles>CCCCCCCCCc1cc(O)cc(O)c1C(=O)[O-]</smiles>

2,4-Dihydroxy-6-nonylbenzoate (48)<smiles>CCOC(=O)c1c(O)cc(O)cc1CCCC(C)CCCC(C)O</smiles>

Ethyl-2,4-dihydroxy-6-(8'-hydroxynonyl) - benzoate (49)<smiles>O=C1C[C@H](O)[C@]23Oc4ccc(O)c5c4C2(OC5=O)Oc2cccc1c23</smiles>

Preussomerin K (52)<smiles>O=C1CCC23Oc4ccc(O)c5c4C2(Oc2cccc(c23)C1=O)O5</smiles>

O<smiles>O=C1C=CC23Oc4ccc(O)c5c4C2(C=CC(=O)c2cccc(c2-5)O1)O3</smiles>

\section{$\mathrm{OH}$}

oi.<smiles></smiles><smiles>COc1cc(O)c2c(=O)cc(C)oc2c1C1C[C@@H](OC)C(=O)O1</smiles><smiles>C/C=C/[C@H]1[C@@H]2C[C@@H](C)CC[C@H]2[C@@](C)(O)[C@@H]2Cc3c(-c4ccc(I)cc4)c[nH]c(=O)c3C(=O)[C@H]12</smiles>

OH<smiles>COC(=O)C(C[C@@H](OC)c1c(OC)cc(O)c2c(=O)cc(C)oc12)OC</smiles>

(57)

Rhytidchromone B (58)<smiles>COc1cc(O)c2c(=O)cc(C)oc2c1C(CC(OC)C(=O)O)OC</smiles>

$\mathrm{R}=\mathrm{CH}_{3}:$ Rhytidchromone $\mathrm{C}$ (59) $\mathbf{R}=\mathbf{H}:$ Rhytidchromone $\mathrm{E}(\mathbf{6 0})$<smiles>C/C=C/[C@H]1[C@@H](C(=O)c2c(O)c(-c3ccc(O)cc3)c[nH]c2=O)C=C(C)[C@@H]2CC[C@@H](C)C[C@H]12</smiles>

Ilicicolin H (62)

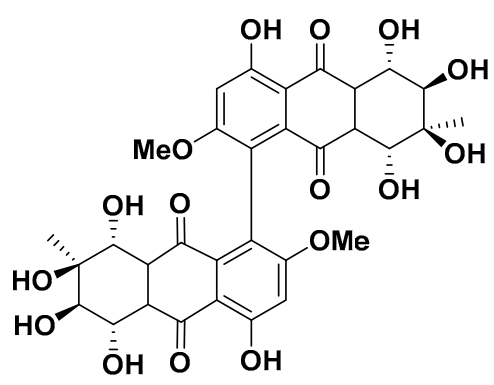

Alterporriol E (67)

Dihydroaltersolanol C (63)<smiles>[R2]C1C2C(=O)c3c(O)cc(OC)cc3C(=O)C2C([R1])[C@@](C)(O)C1[R3]</smiles>

$\mathbf{R}_{1}=\mathbf{R}_{\mathbf{2}}=\mathrm{OH}, \mathbf{R}_{\mathbf{3}}=\mathrm{H}$ :Altersolanol A (64)

$\mathbf{R}_{\mathbf{1}}=\mathbf{R}_{\mathbf{2}}=\mathbf{R}_{\mathbf{3}}=\mathbf{H}$ : Altersolanol B (65)

$R_{1}=R_{2}=O H, R_{3}=A C:$ Altersolanol N (66)

Figure 4. Structures of metabolites isolated from Ascomycetes (47-67).

Two new chlorinated preussomerins, chloropreussomerins A (50), and B (51), and a known preussomerin analog preussomerin $\mathrm{K}$ (52), preussomerin $\mathrm{H}$ (53), preussomerin $\mathrm{G}$ (54), preussomerin F (55), preussomerin D (56) (Figure 4), were obtained from the endophytic fungus Lasiodiplodia theobromae 
ZJ-HQ1 isolated from Excoecaria agallocha collected from Guangdong Province, China. Compounds 50-51 and $\mathbf{5 6}$ were found to be active against the A549 and MCF-7 cell lines with $\mathrm{IC}_{50}$ values ranging from 5.9-8.9 $\mu \mathrm{M}$, and compounds 52-55 showed cytotoxicity against A549, HepG2, and MCF-7 human cancer cell lines with $\mathrm{IC}_{50}$ values of 2.5-9.4 $\mu \mathrm{M}$ [37].

Four highly oxygenated chromones—rhytidchromone A (57), B (58), C (59) and E (60) (Figure 4) were obtained from Rhytidhysteron rufulum BG2-Y, an endophyte associated with the leaves of Bruguiera gymnorrhiza collected from Prachuab Kiri Khan Province, Thailand. Compounds 57-60 were found to be active against Kato-3 cell lines, with $\mathrm{IC}_{50}$ values in the range of $16.0-23.3 \mu \mathrm{M}$, while the rhytidchromones $\mathrm{A}$ and $\mathrm{C}$ were active, with $\mathrm{IC}_{50}$ values of 19.3 and $17.7 \mu \mathrm{M}$ respectively, against MCF-7 cell lines [38].

Campyridone D (61) and ilicicolin H (62) (Figure 4) were extracted from Campylocarpon sp. HDN13-307, an endophyte associated with the root of the mangrove plant Sonneratia caseolaris. Compounds 61 and 62 showed cytotoxicity, with the $\mathrm{IC}_{50}$ values of $8.8 \mu \mathrm{M}$ and $4.7 \mu \mathrm{M}$, respectively, against HeLa cells [39].

Stemphylium globuliferum, an endophytic fungus associated with the Egyptian mangrove plant Avicennia marina, was the source of dihydroaltersolanol C (63), altersolanols A, B, N $(64,65,66)$, and alterporriol E (67) (Figure 4) [40]. Compounds 63, 64, 65, and 67 showed cytotoxicity with $\mathrm{IC}_{50}$ values of 3.4, 2.5, 3.7 and $6.9 \mu \mathrm{M}$, respectively, towards L5178Y cells [41]. Compound 66 also showed good activity, with $\mathrm{IC}_{50}$ values in the low micro-molar range towards L5178Y cells [42]. Mishra et al. [43] reported that compound 64 exhibited cytotoxicity against 34 human cancer cell lines in vitro, with mean $\mathrm{IC}_{50}\left(\mathrm{IC}_{70}\right)$ values of $0.005 \mu \mathrm{g} / \mathrm{mL}(0.024 \mu \mathrm{g} / \mathrm{mL})$. It has also been reported that compound $\mathbf{6 4}$ is a kinase inhibitor and induces cell death by apoptosis through the caspase-dependent pathway, and that kinase inhibition might be the mechanism for the cytotoxic activity [44]. The pro-apoptotic and anti-invasive activity of compound $\mathbf{6 4}$ that occurred through the inhibition of the NF- $\mathrm{KB}$ transcriptional activity may be responsible for its antitumor potential [45].

Two new hydroanthraquinones, paradictyoarthrins A (68) and B (69) and the known compounds, preussomerin C (70), ymf 1029C (71) and altenusin (72) (Figure 5), were isolated from Paradictyoarthrinium diffractum BCC 8704, an endophyte associated with mangrove wood in Laem Son National Park, Ranong Province, Thailand. Compounds 68-72 were evaluated for cytotoxic activity against cancer cell-lines, KB, MCF-7, and NCI-H187, and noncancerous Vero cells. Compound 69 exhibited moderate cytotoxicity against KB, MCF-7 NCI-H187 and Vero cell lines with $\mathrm{IC}_{50}$ of 3.1, 3.8, 9.5 and $5.6 \mu \mathrm{g} / \mathrm{mL}$, respectively, whereas Compound 68 showed weaker activity with $\mathrm{IC}_{50}$ values in the range of 23-31 $\mu \mathrm{g} / \mathrm{mL}$. Compounds $\mathbf{7 0 - 7 2}$ showed average to poor activity in tested cell lines. Compound ymf 1029C 71 showed relatively stronger cytotoxicity on NCI-H187 cells than other cell-lines (IC $505.0 \mu \mathrm{g} / \mathrm{mL})$ [46].

A marine anthraquinone derivative SZ-685C (73) (Figure 5) has been isolated from the mangrove endophytic fungus Halorosellinia sp. (No. 1403), which was found in the South China Sea. The $\mathrm{IC}_{50 \mathrm{~s}}$ of SZ-685C in nonfunctioning pituitary adenoma (NFPA), MMQ, and RPC cells were 18.76, 14.51, and $56.09 \mu \mathrm{M}$, respectively. Hoechst 33342 dye/propidium iodide (PI) double staining and fluorescein isothiocyanate-conjugated Annexin V/PI (Annexin V-FITC/PI) apoptosis assays detected an enhanced the rate of apoptosis in cells treated with SZ-685C. Enhanced expression levels of caspase 3 and phosphate and tensin homologs were determined by Western blotting. The protein expression levels of Akt were decreased when the primary human NFPA cells were treated with SZ-685C. It has been observed that SZ-685C (73) induces the apoptosis of human NFPA cells through the inhibition of the Akt pathway in vitro. These findings suggest that SZ-685C may be a potentially promising Akt inhibitor and anti-cancer agent for the treatment of NFPA [47]. 


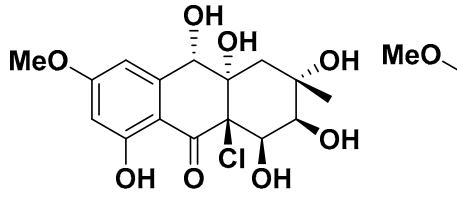

Paradictyoarthrin A (68)<smiles>O=C1c2c(O)cccc2C(=O)C23CC1(CCC(O)(O)C2O)C3O</smiles>

Paradictyoarthrin B (69)

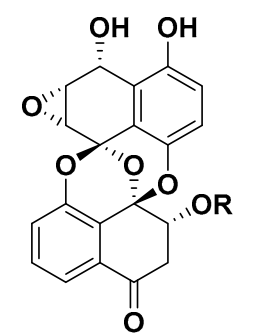<smiles>COc1cc(O)c(C(=O)O)c(-c2cc(O)c(O)cc2C)c1</smiles>

$\mathrm{R}=\mathrm{Me}:$ Preussomerin C (70) Altenusin (72) $\mathrm{R}=\mathrm{H}:$ YMF1029C (71)<smiles>COc1cc(O)c2c(c1O)C(=O)C1=C(C2)C(O)C(O)C(O)C1O</smiles><smiles>CCCCCCCCCCCCCC(C)c1c(O)cc(O)cc1CC(=O)OC</smiles>

Dothiorelone F (74)

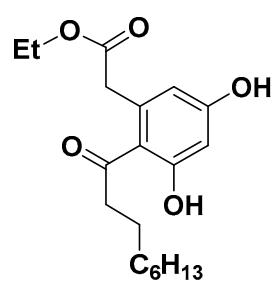

Dothiorelone G (75)

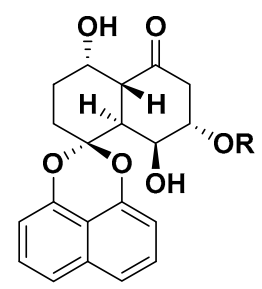<smiles></smiles>

$\mathrm{R}=\mathrm{O}:$ MK3018 (78)

$\mathrm{R}=\mathrm{H}, \mathrm{OH}$ :

Palmarumycin CR1 (79)<smiles>[R]c1cc(O)c2c(c1)C1(c3cccc(O)c3C(=O)O)c3cccc(O)c3C(=O)CC1CC2=O</smiles><smiles></smiles>

$\mathrm{R}=$ Me : Rhytidone C (77)<smiles>C=CC(C)(C)c1[nH]c(CC=C(C)C)c2cc(CC=C(C)C)cc(C=C3NC(=O)NC(=O)C3=O)c12</smiles>

$\mathbf{R}=\mathbf{H}:$ Sporothrin $A(\mathbf{8 0})$ $\mathrm{R}=\mathrm{OH}$ : Sporothrin $\mathrm{B}(\mathbf{8 1})$

Sporothrin C (82)

$\mathrm{MeO}$<smiles>Cc1cc(O)c2c(=O)oc(CC(C)O)cc2c1</smiles>
-eurotechinulin B (84)<smiles>Cc1cc(O)c2c(c1)Cc1cc(O)cc(O)c1OC2=O</smiles><smiles>C=CC(C)(C)c1[nH]c2c(CC=C(C)C)cccc2c1/C=C1\NC(=O)C(C)NC1=O</smiles>

Diaporthin (83)<smiles>Cc1cc(O)c2c(c1)C(=O)c1cc(O)cc(O)c1C2=O</smiles>

Emodin (88)

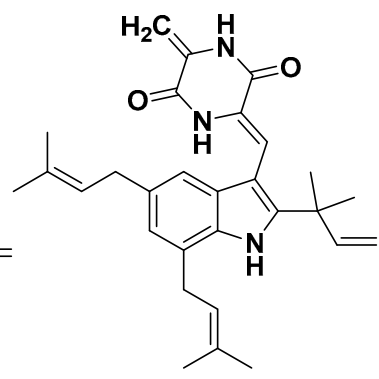

Alkaloid E-7 (87)<smiles>C=C(C)CCOc1ccc(C[C@H](NC(=O)[C@@H]([C@@H](C)CC)N(C)C(=O)[C@H](C)NC(=O)C2CCCN2C(=O)C(Cc2ccccc2)OC(=O)C(C)N(C)C)C(=O)N2CCC[C@H]2C)cc1</smiles>

Pullularin E (89)<smiles>C=C(C)CCOc1ccc(C[C@H](NC(=O)C([C@@H](C)CC)N(C)C(=O)[C@H](CO)NC(=O)C2CCCN2C(=O)C(O)Cc2ccccc2)C(=O)O)cc1</smiles>

Pullularin F (90)

Figure 5. Structures of metabolites isolated from Ascomycetes (68-90)

SZ-685C (73), was previously reported to inhibit the proliferation of certain tumor cells. SZ-685C inhibited MMQ cell growth in a dose-dependent manner but showed little toxicity toward rat pituitary cells. The $\mathrm{IC}_{50}$ of SZ-685C in MMQ cells and RPCs were 13.2 and $49.1 \mu \mathrm{M}$, respectively. Increasing 
numbers of apoptotic cells were observed in response to escalating concentrations of SZ-685C, and the expression level of prolactin was inhibited. Nevertheless, the level of prolactin mRNA was unchanged. Additionally, miR-200c was upregulated in MMQ cells compared with RPCs, and downregulation of miR-200c was observed in SZ-685C-treated MMQ cells. Furthermore, the overexpression of miR-200c weakened the effect of the SZ-685C-induced apoptosis of MMQ cells. It has been suggested that SZ-685C induces MMQ cell apoptosis in a miR-200c-dependent manner [48].

Two new polyketides, named dothiorelons F (74) and G (75) (Figure 5), were isolated from Dothiorella sp., an endophytic fungus associated with the bark of the mangrove tree Aegiceras corniculatum at the estuary of Jiulong River, Fujian Province, China. Compounds $\mathbf{7 4}$ and 75 showed significant cytotoxicity against the Raji cancer cell line, with an $\mathrm{IC}_{50}$ value of $2 \mu \mathrm{g} / \mathrm{mL}$ [49].

New spironaphthalenes, rhytidones B-C (76, 77) and known MK3018 (78), palmarumycin CR1 (79) (Figure 5), were extracted from Rhytidhysteron sp. an endophytic fungus associated with the leaves of Azima sarmentosa, collected from the mangrove forest in Samutsakhon province, Thailand. Compound 76 was found to be poorly active against CaSki cells, with an $\mathrm{IC}_{50}$ value of $22.81 \mu \mathrm{M}$, while compounds 77-79 showed average activity against the MCF-7 and CaSkicell lines with $\mathrm{IC}_{50}$ values in the range of 14.47 and $25.59 \mu \mathrm{M}$ [50].

Sporothrix sp. isolated from the bark of an inshore mangrove sample Kandelia candel in the South China Sea was the source of Sporothrin A (80), sporothrin B (81), sporothrin C (82), diaporthin (83) (Figure 5). Compounds 81-83 were found to show weak cytotoxic activity with $\mathrm{IC}_{50}$ values of 20 , 23, and $23 \mathrm{~g} / \mathrm{mL}$, respectively. Compound 80 exhibited strong inhibition of $\mathrm{AChE}$ in vitro $\left(\mathrm{IC}_{50}\right.$ was $1.05 \mu \mathrm{M})$ [51].

A new dioxopiperazine alkaloid, 12-demethyl-12-oxo-eurotechinulin B (84), and one new anthraquinone derivative 9-dehydroxyeurotinone (85), and known compounds, variecolorin G (86), alkaloid E-7 (87), and emodin (88) (Figure 5), were isolated from Eurotium rubrum, an endophytic fungus associated with the inner tissue of Hibiscus tiliaceus, collected from Hainan Island, China. Compounds 84-88 displayed cytotoxic activity against one or two of the MCF-7, SW1990, HepG2, NCI-H460, SMMC7721, Hela, and Du145 cell lines in the range of 15-30 mg/mL [52].

Two new peptides-pullularins E (89) and F (90) (Figure 5)—and three known compoundspullularins A (91) and C (92) and verticillin D (93) (Figure 6) -were extracted from Bionectria ochroleuca, an endophytic fungus associated with the inner leaf tissues of Sonneratia caseolaris from Hainan island, China. Compound 93 showed potent to moderate activity against L5178Y cell lines with an $\mathrm{EC}_{50}$ value of $<0.1 \mu \mathrm{g} / \mathrm{mL}$. Compounds 89-92 also exhibited potent to average activity against the L5178Y cell lines, with $\mathrm{EC}_{50}$ values ranging between 0.1 and $6.7 \mu \mathrm{g} / \mathrm{mL}$ [53].

\subsection{Compounds Produced by Hyphomycetes}

New isocoumarin derivatives, aspergisocoumrins A (94) and B (95) (Figure 6) were obtained from the culture of the endophytic fungus Aspergillus sp. HN15-5D derived from the fresh leaves of the mangrove plant Acanthus ilicifolius collected from Dongzhaigang Mangrove National Nature Reserve on Hainan Island, China. Compounds 94 and 95 exhibited cytotoxicity against MDA-MB-435, with $\mathrm{IC}_{50}$ values of 5.08 and $4.98 \mu \mathrm{M}$, respectively [54].

Two new 6,8(14),22-hexadehydro-5 $\alpha, 9 \alpha$-epidioxy-3,15-dihydroxy sterols, nigerasterols A (96) and B (97) (Figure 6), were isolated from Aspergillus niger MA-132, an endophytic fungus associated with Avicennia marina. Compounds 96-97 displayed cytotoxicity against the HL60 cell line with an $\mathrm{IC}_{50}$ value of 0.30 and $1.50 \mu \mathrm{M}$, respectively. Compounds $\mathbf{9 6 - 9 7}$ also exhibited potent activity against the A549 cell line with $\mathrm{IC}_{50}$ values of 1.82 and $5.41 \mu \mathrm{M}$, respectively [55].

Four new quinazolinone alkaloids, namely, aniquinazolines A-D (98-101) (Figure 6), were identified from Aspergillus nidulans MA-143, an endophytic fungus associated with the leaves of the marine mangrove plant Rhizophora stylosa. Compounds $\mathbf{9 8 - 1 0 1}$ showed potent lethality against brine shrimp with $\mathrm{LD}_{50}$ values of $1.27,2.11,4.95$ and $3.42 \mu \mathrm{M}$, respectively, which were stronger than that of the positive control colchicine (with the $\mathrm{LD}_{50}$ value of $88.4 \mu \mathrm{M}$ ) [56]. 


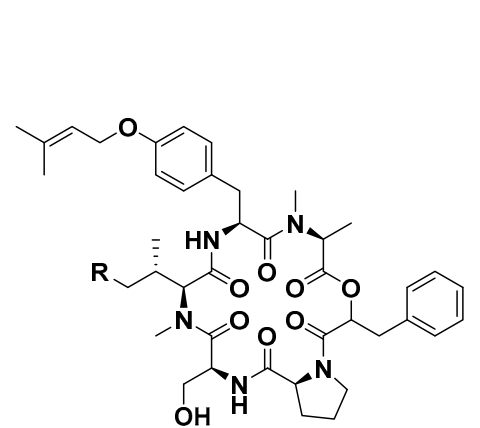

$R=$ Me : Pullularin A (91) $\mathrm{R}=\mathrm{H}$ : Pullularin C (92)

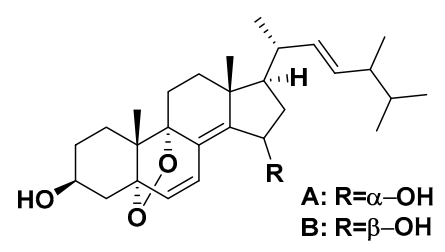

Nigerasterols A and B $(96,97)$<smiles>CC(C)[C@H]1C(=O)N2c3ccccc3[C@@]3(O)C[C@H](n4cnc5ccccc5c4=O)C(=O)N1C23</smiles>

Aniquinazolines D (101)

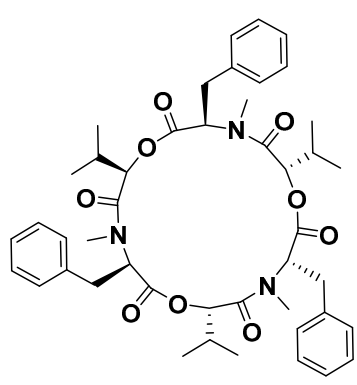

Beauvericin (104)

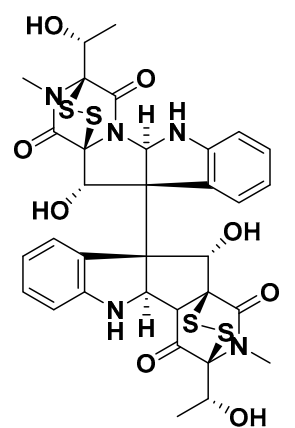

Verticillin $D$ (93)

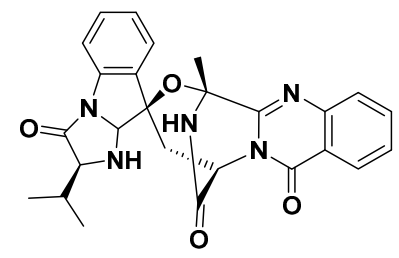

Aniquinazolines A (98)

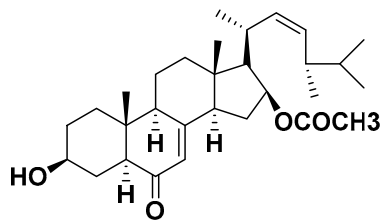

$3 \beta, 5 \alpha$-dihydroxy-(22E,24R)ergosta-7,22-dien-6-one (102)<smiles>C=C(CC)/C(=C\c1cc2cc(OC)cc(O)c2c(=O)o1)C(=O)OC</smiles>

Aspergisocoumrin A (94)<smiles>COC(=O)/C=C\c1cc2cc(OC)cc(O)c2c(=O)o1</smiles>

Aspergisocoumrin B (95)

$$
\mathbf{R}=\mathbf{H} \text { : Aniquinazolines B (99) }
$$
$\mathrm{R}=\mathrm{OH}$ : Aniquinazolines $\mathrm{C}(\mathbf{1 0 0})$

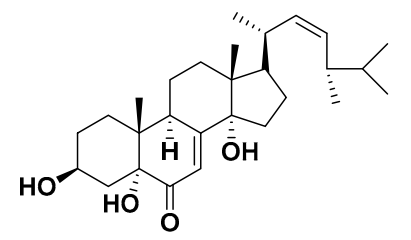

$3 \beta, 5 \alpha, 14 \alpha$-trihydroxy-(22E,24R) -ergosta-7,22-dien-6-one(103)

Figure 6. Structures of metabolites isolated from Ascomycetes (91-93) and Hyphomycetes (94-107).

The compounds $3 \beta, 5 \alpha$-Dihydroxy-(22E,24R)-ergosta-7,22-dien-6-one (102), $3 \beta, 5 \alpha, 14 \alpha$-trihydroxy(22E,24R)-ergosta-7,22-dien-6-one (103), and beauvericin (104) (Figure 6), were extracted from Aspergillus terreus (No. GX7-3B), a mangrove endophytic fungus isolated from the leaves of Rhizophora stylosa. Compounds 102 and 104 exhibited good or moderate cytotoxic activity against MCF-7, A549, HeLa and KB cell lines with $\mathrm{IC}_{50}$ values of $4.98,1.95,0.68,1.50$ and $2.02,0.82,1.14,1.10 \mu \mathrm{M}$, respectively; compound 103 exhibited poor activity against the cell lines tested, namely MCF-7 (25.4 $\mu \mathrm{M})$, A549 $(27.1 \mu \mathrm{M})$, HeLa $(24.4 \mu \mathrm{M})$ and $\mathrm{KB}(19.4 \mu \mathrm{M})$ [57].

A new compound, botryosphaerin F (105), and a known compound, LL-Z1271 $\beta$ (106) (Figure 6), were obtained from the mangrove fungus Aspergillus terreus (No. GX7-3B) isolated from the branch of Brugnieria gymnoihiza, growing in a coastal salt marsh of the South China Sea in Guangxi Province, China. Compound 105 showed potent inhibiting activity towards the MCF-7 and HL-60 cancer cell lines with $\mathrm{IC}_{50}$ values of 4.49 and $3.43 \mu \mathrm{M}$, respectively, and compound 106 exhibited promising activity against the HL-60 cell line with an $\mathrm{IC}_{50}$ value of $0.6 \mu \mathrm{M}$ [58]. 
A new eudesmane-type sesquiterpenoid, penicieudesmol B (107) (Figure 6), was isolated from the mangrove-derived endophytic fungus Penicillium sp. J-54 associated with the leaves of Ceriops tagal, which were collected in Dong Zhai Gang Mangrove Reserve in Hainan province, China. Compound 107 exhibited weak cytotoxicity against K-562 with an $\mathrm{IC}_{50}$ value of $90.1 \mu \mathrm{M}$, with paclitaxel as the positive control $\left(\mathrm{IC}_{50}=9.5 \mu \mathrm{M}\right)[59]$.

A new compound Penibenzophenone B (108) (Figure 7), was obtained from the endophytic fungus Penicillium citrinum HL-5126 isolated from the mangrove Bruguiera sexangula var. rhynchopetala collected in the South China Sea. The new compound 108 displayed cytotoxic activity against human A549 cell lines with an $\mathrm{IC}_{50}$ value of $15.7 \mu \mathrm{g} / \mathrm{mL}$ [60].

Five new derivatives of macrolide antibiotic Brefeldin A (109), along with Brefeldin A 7-O-acetate (110) (Figure 7), were produced by an endophytic fungus, Penicillium sp., which was isolated from the healthy root of Panax notoginseng. Compounds 109-110 exhibited cytotoxic activity against the 293, HepG2, Huh7 and KB cell line with an $\mathrm{ID}_{50}$ values from 0.024 to $0.62 \mu \mathrm{M}$. Further, studies of the cellular mechanism of compounds 109-110 showed that they arrested HepG2 cells at the S phase [61].

A new chaetoglobosin, penochalasin K (111) (Figure 7), was extracted from the mangrove endophytic fungus Penicillium chrysogenum V11. Its structure was elucidated by 1D, 2D NMR spectroscopic analysis and high resolution mass spectroscopic data. Compound 111 showed strong cytotoxicity against the MDA-MB-435, SGC-7901 and A549 cell lines with an $\mathrm{IC}_{50}$ less than $10 \mu \mathrm{M}$ [62].

The new epipolythiodioxopiperazine alkaloids, penicisulfuranols A-C (112-114) (Figure 7), were obtained from Penicillium janthinellum HDN13-309, the mangrove endophytic fungus associated with Sonneratia caseolaris collected from Hainan Province, China. Compounds 112-114 showed cytotoxicity against HeLa and HL-60 cell lines, with $\mathrm{IC}_{50}$ values ranging from 0.1 to $3.9 \mu \mathrm{M}$ [63].

Penicillium chrysogenum V11, a mangrove endophytic fungus was the source of a novel chaetoglobosin named penochalasin I (115), along with chaetoglobosins A (116), and cytoglobosin C (117) (Figure 7). Compound 115 exhibited marked cytotoxicity against MDA-MB-435 and SGC-7901 cells $\left(\mathrm{IC}_{50}<10 \mu \mathrm{M}\right)$, and compounds $\mathbf{1 1 6}$ and $\mathbf{1 1 7}$ showed potent cytotoxicity against SGC-7901 and A549 cells $\left(\mathrm{IC}_{50}<10 \mu \mathrm{M}\right)$ [64].

Using the one strain many compounds (OSMAC) approach, new diketopiperazines, spirobrocazine C (118) and brocazine G (119) (Figure 7) were characterized from Penicillium brocae MA-231, an endophytic fungus associated with Avicennia marina collected at Hainan Island, China. Compound 119 exhibited potent cytotoxic activity against the A2780 and A2780 CisR cell lines, with $\mathrm{IC}_{50}$ values of 664 and $661 \mathrm{nM}$, respectively. This activity is higher than the cisplatin where the $\mathrm{IC}_{50}$ values were reported as 1.67 and $12.63 \mu \mathrm{M}$, respectively. Compound 118 showed moderate activity against $\mathrm{A} 2780$ cells with an $\mathrm{IC}_{50}$ value of $59 \mu \mathrm{M}$ [65]. Previously reported disulfide-bridged diketopiperazine derivatives, brocazines A (120), B (121), E (122), F (123) (Figure 7) were isolated from the same fungus. Compounds 120-123 displayed cytotoxic activity against the Du145, HeLa, HepG2, MCF-7, NCI-H460, SGC-7901, SW1990, SW480, and U251 cell lines with IC $_{50}$ values ranging from 0.89 to $9.0 \mu \mathrm{M}$. Compounds $\mathbf{1 2 1}$ and $\mathbf{1 2 2}$ exhibited strong activity against the SW480 cell line with $\mathrm{IC}_{50}$ values of 2.0 and $1.2 \mu \mathrm{M}$, respectively, while compound $\mathbf{1 2 3}$ showed potent activity against the DU145 and NCI-H460 cell lines, with IC $_{50}$ values of 1.7 and $0.89 \mu \mathrm{M}$, respectively [66].

The fungal metabolites TMC-264 (124), and PR-toxin (125) (Figure 7) were obtained from Penicillium chermesinum strain HLit-ROR2, an endophytic fungus associated with the root of Heritiera littoralis, collected from Samut Sakhon province, Thailand. Compound $\mathbf{1 2 4}$ showed cytotoxicity against T47D and MDA-MB231 cell lines with the $\mathrm{IC}_{50}$ value of 1.08 and $2.81 \mu \mathrm{M}$, respectively, while a positive control, doxorubicin, showed activity with $\mathrm{IC}_{50}$ of 1.55 and $2.24 \mu \mathrm{M}$ respectively. Compound 124 also showed cytotoxic activity against the HepG2 cell line, with an $\mathrm{IC}_{50}$ value of $3.27 \mu \mathrm{M}$, which was 11 times more potent than that of etoposide, an anticancer drug $\left(\mathrm{IC}_{50} 35.66 \mu \mathrm{M}\right)$. Besides, compound 124 selectively exhibited cytotoxic activity toward MOLT-3 and T47D cancer cells with the $\mathrm{IC}_{50}$ values of 1.36 and $1.08 \mu \mathrm{M}$ and with selectivity index (SI) values of 9 and 11, respectively ( $\mathrm{IC}_{50} 12.64 \mu \mathrm{M}$ for the normal cell line, MRC-5). Compound 125 exhibited cytotoxicity against the HuCCA-1, HeLa, T47D, 
and MDA-MB231 cell lines with $\mathrm{IC}_{50}$ values in the range of $0.81-2.19 \mu \mathrm{M}$, which was comparable to that of doxorubicin ( $\mathrm{IC}_{50} 0.26-2.24 \mu \mathrm{M}$ ). Interestingly, the compound 125 exhibited cytotoxicity against the HL-60 cell line with an $\mathrm{IC}_{50}$ value of $0.06 \mu \mathrm{M}$, which is superior to doxorubicin ( $\mathrm{IC}_{50} 1.21 \mu \mathrm{M}$ ). Compound 125 selectively showed cytotoxic activity against MOLT-3 and HL-60 cancer cell lines with $\mathrm{IC}_{50}$ of 0.09 and $0.06 \mu \mathrm{M}$, respectively, with respective SI values of 40 and 61 (IC $50.66 \mu \mathrm{M}$ for the MRC-5 cell line) [67].<smiles>COC(=O)c1cc(C)cc(O)c1C(=O)c1c(O)cc(OC)cc1OC</smiles>

Penibenzophenone B (108)

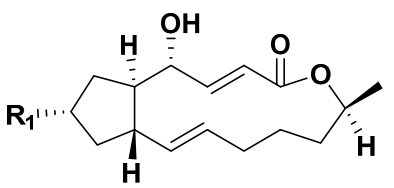

$R=O H:$ Brefeldin A (109)

$R=$ OAc : Brefeldin A 7-O-acetate (110)

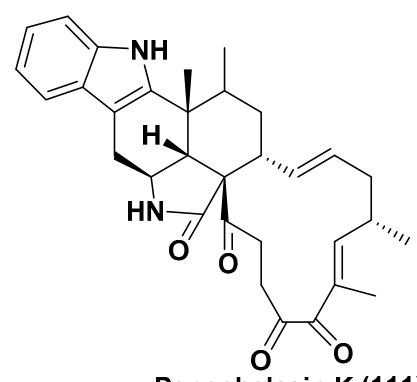

Penochalasin K (111)

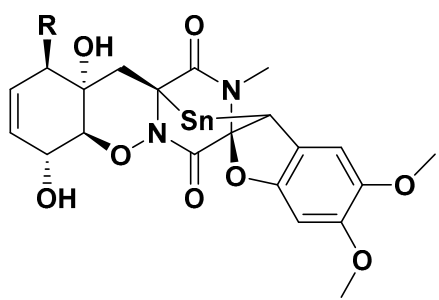

$\mathrm{R}_{1}=\mathrm{OH}, \mathrm{R}_{\mathbf{2}}=\mathrm{H}:$ Penicisulfuranol A (112)

$R_{1}=C l, R_{2}=H$ : Penicisulfuranol B (113)

$R_{1}=O H, R_{2}=M e:$ Penicisulfuranol C (114)

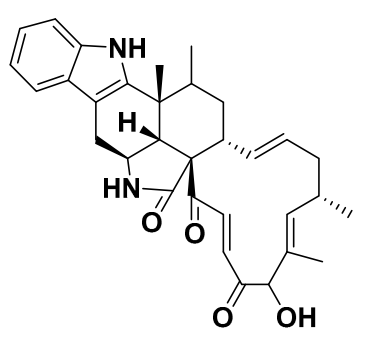

Penochalasin I (115)

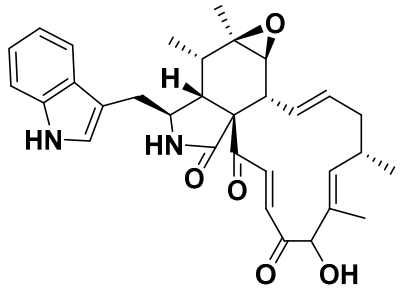

Chaetoglobosin A (116)

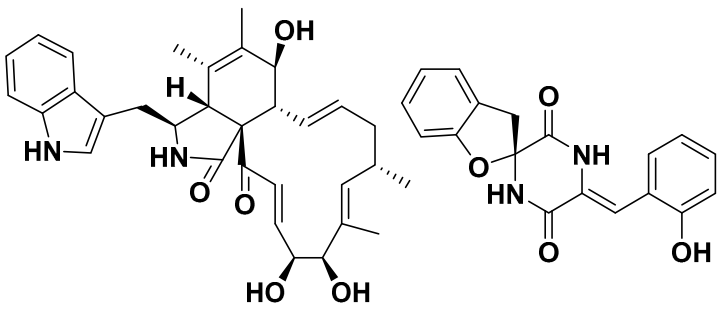

Cytoglobosin C (117) Spirobrocazine C (118)
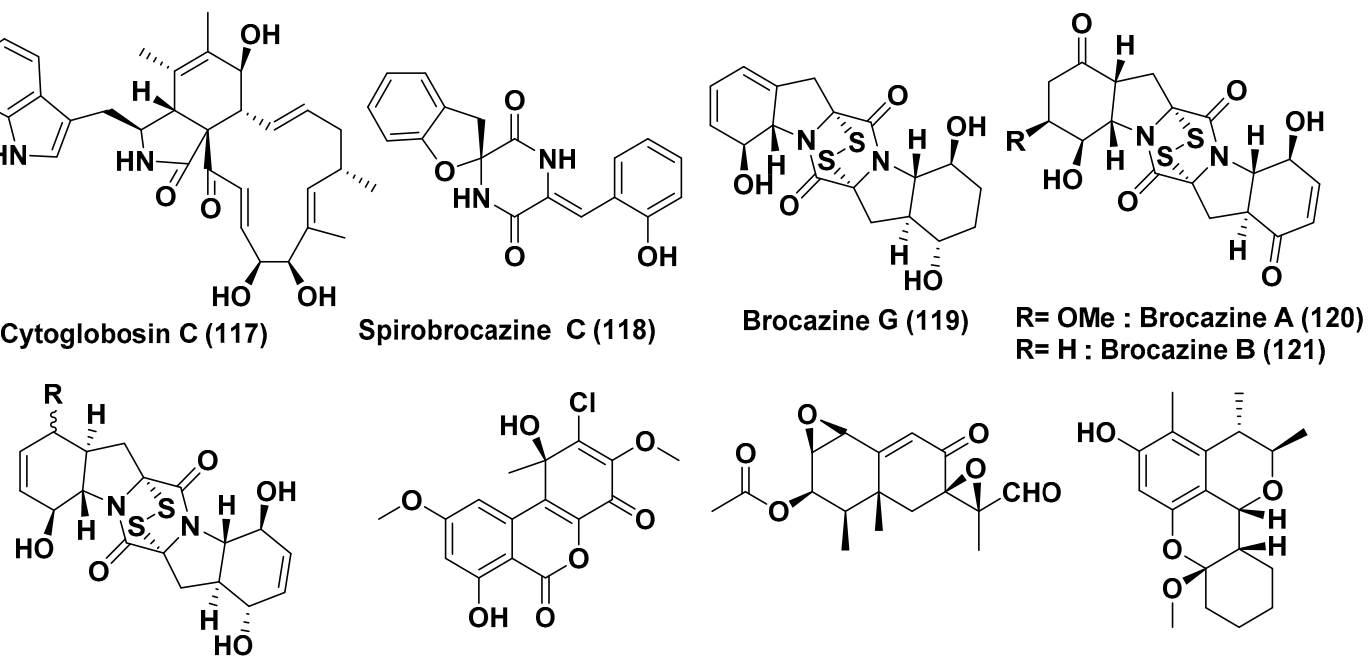<smiles>CC(=O)OC1C2OC2C=C2OC(C)(C=O)C2(C)CC12CO2</smiles>

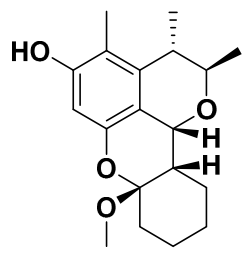

$\mathrm{R}=\alpha-\mathrm{OH}, \beta-\mathrm{H}$ : Brocazine $\mathrm{E}(122)$ $\mathrm{R}=\mathrm{O}$ : Brocazine $\mathrm{F}$ (123)<smiles>CO[C@H]1Cc2c(O)c(Oc3cc(O)cc4c3C(=O)O[C@H](C)C4C)c(O)c(O)c2C(C)[C@@H]1C</smiles><smiles>COC(=O)c1ccc2c(=O)c3cc(O)cc(C(=O)O)c3oc2c1O</smiles>

Penixanacid A (129)<smiles>CC(O)C(O)COc1ccc(CCO)cc1</smiles>

Figure 7. Structures of metabolites isolated from Hyphomycetes (108-130). 
Three new citrinin analogs, penicitols A-C (126-128), and one new xanthone derivative, penixanacid A (129) (Figure 7), were isolated from Penicillium chrysogenum HND11-24 isolated from the rhizosphere soil of Acanthus ilicifolius. Compounds 126-127 showed good activity against the HeLa, BEL-7402, HEK-293, HCT-116, and A549 cell lines with IC $_{50}$ values of 4.6-10.5 and 3.4-9.6 $\mu \mathrm{M}$, respectively. Compounds 128-129 exhibited cytotoxicity against the HeLa, BEL-7402, HEK-293, HCT-116, and A549 cell lines with $\mathrm{IC}_{50}$ values of 10-40.5 $\mu \mathrm{M}$ [68].

Two new metabolites, compounds 130 (Figure 7) and $\mathbf{1 3 1}$ (Figure 8), were obtained from Penicillium sp. FJ-1, associated with Avicennia marina collected in Fujian, China. Compound 131 exhibited anti-proliferative activity against Tca8113, MG-63 and the normal liver cell line WRL-68 with an $\mathrm{IC}_{50}$ value of $10 \mu \mathrm{M}, 55 \mathrm{nM}$ and $58 \mu \mathrm{M}$, respectively. Compound $\mathbf{1 3 1}$ has also shown a significant inhibition of tumor growth of human osteosarcoma when tested against nude mice. Compound 130 exhibited weak activity against Tca8113 and MG-63 cells with the $\mathrm{IC}_{50}$ values of $26 \mu \mathrm{M}$ and $35 \mu \mathrm{M}$, respectively, in the anti-proliferative assay. Taxol, the positive control, showed activity against Tca8113 and MG-63 cell lines with $\mathrm{IC}_{50}$ values of $46 \mathrm{nM}$ and $10 \mathrm{nM}$, respectively [69].

Meleagrin (132) (Figure 8) was isolated from the endophytic fungus Penicillium sp. GD6, associated with the Chinese mangrove Bruguiera gymnorrhiza collected off the coasts of Zhanjiang, China. Compound 132 showed potent cytotoxic activity against two tumor cell lines, HL60 and A549, with IC 50 values of 9.7 and $8.3 \mu \mathrm{M}$, respectively [70].

Mangrove endophytic fungus, Penicillium 303\# obtained from the sea water in Zhanjiang Mangrove National Nature Reserve in Guangdong Province, China, was the source of compounds 133, 134, 135 and 136 (Figure 8). Compounds 133-135 exhibited cytotoxicity against MDA-MB-435, HepG2, HCT-116, and A549 with $\mathrm{IC}_{50}$ value of 11.9-37.82 $\mu \mathrm{g} / \mathrm{mL}$. Compound 136 showed strong cytotoxic activity against the MDA-MB-435 cell lines with $\mathrm{IC}_{50}$ values of $7.13 \mu \mathrm{M}$ and average to low activity against the HepG2 and HCT-116 cell lines with $\mathrm{IC}_{50}$ values of 39.64 and $27.80 \mu \mathrm{M}$, respectively [71].

A new isobenzofuranone, 4-(methoxymethyl)-7-methoxy-6-methyl-1(3H)-isobenzofuranone (137) (Figure 8), was isolated from the mangrove endophytic fungus, Penicillium sp. ZH58, which was associated with the leaves of mangrove tree Avicennia from Dong Sai, Hainan, on the South China Sea coast. Compound 137 showed cytotoxic activity against the $\mathrm{KB}$ and $\mathrm{KB}_{\mathrm{V}} 200$ cell lines with $\mathrm{IC}_{50}$ values of 6 and $10 \mu \mathrm{g} / \mathrm{mL}$, respectively [72].

The new and rare sulfur-containing curvularin derivatives sumalarins A, B, (138, 139) C (140) (Figure 8), and dehydrocurvularin (141) (Figure 8) were obtained from Penicillium sumatrense MA-92, isolated from the rhizosphere of the mangrove Lumnitzera racemose collected at Wen Chang on Hainan Island, China. Compounds 138-141 displayed cytotoxic activities against the Du145, HeLa, Huh 7, MCF-7, NCI-H460, SGC-7901, and SW1990 cell lines, with $\mathrm{IC}_{50}$ values in the range of 3.8 to $10 \mu \mathrm{M}$ [73].

Penicillium sp. ZH16, a mangrove endophytic fungus, obtained from the South China Sea, was the source of the furanocoumarin 5-methyl-8-(3-methylbut-2-enyl) furanocoumarin (142) (Figure 8). Compound 142 exhibited cytotoxicity against the $\mathrm{KB}$ and $\mathrm{KB}_{\mathrm{V}} 200$ cell lines with $\mathrm{IC}_{50}$ values of 5 and $10 \mu \mathrm{g} / \mathrm{mL}$, respectively [74].

Zhang et al. [75] reported the production of the compounds (3S)-6-oxo-de-O-methyllasiodiplodin (143), (3R)-de-O-methyllasiodiplodin (144), (3R)-nordinone (145) (Figure 8), by the co-culturing of mangrove endophytic fungus Trichoderma sp. 307 isolated from the stem bark of Clerodendrum inerme, and the aquatic pathogenic bacterium Acinetobacter johnsonii B2 isolated from the stem bark of Clerodendrum inerme, collected in Zhanjiang Mangrove National Nature Reserve in Guangdong Province, China. Compound 144 exhibited good cytotoxic activity against the GH3 and MMQ cell lines with $\mathrm{IC}_{50}$ values of 6.44 and $6.58 \mu \mathrm{M}$, respectively, and against rat normal pituitary cells (RPC) with an $\mathrm{IC}_{50}$ value of $6.94 \mu \mathrm{M}$. Compound 145 displayed average cytotoxic activity against the GH3 and MMQ cell lines with $\mathrm{IC}_{50}$ values of 12.33 and $10.13 \mu \mathrm{M}$, respectively, and against RPC cell lines with an $\mathrm{IC}_{50}$ value of $100.03 \mu \mathrm{M}$. Compound 143 was less active against the GH3 and MMQ cell lines with $\mathrm{IC}_{50}$ values of 21.42 and $13.59 \mu \mathrm{M}$, respectively, and against the RPC cell lines with an $\mathrm{IC}_{50}$ value of $142.8 \mu \mathrm{M}$ as a positive control [75]. 
<smiles>CC1CCC2CC(=O)O[C@]23C=C(CO)CC[C@H]13</smiles>

Compound (131)

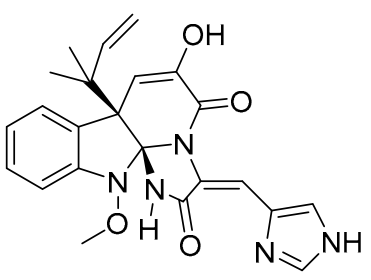

Meleagrin (132)

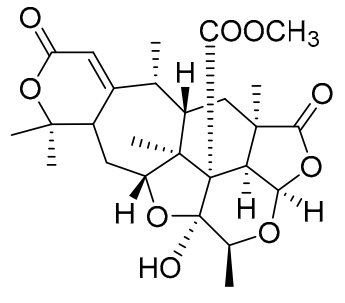

Compound (133)

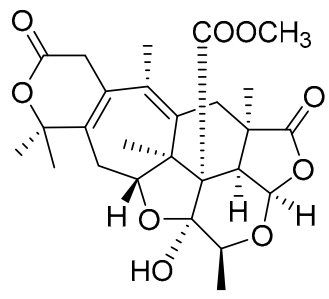

Compound (134)<smiles>CCC(C)/C=C(C)/C=C/C1=CC2=C(O)C(=O)C(O)(O)C(=O)C2=CO1</smiles>

Compound (135)<smiles></smiles><smiles>COCc1cc(C)c(OC)c2c1COC2=O</smiles>

Compound (136)

4-(Methoxymethyl)-7-methoxy6-methyl-1(3H)-isobenzofuranone (137)<smiles>[R2]C(=O)[C@H](O)CS[C@H]1CCC[C@@H](C)OC(=O)Cc2cc(O)cc(O)c2C(=O)C1</smiles><smiles>CC(=O)OCCOC(=O)C(CS[C@H]1CCCCOC(=O)Cc2cc(O)cc(O)c2C(=O)C[C@@H]1OC(C)=O)OC(C)=O</smiles>

Sumalarins B (139)

$\mathrm{R}=\mathrm{CH}_{3}$ : Sumalarins $\mathrm{A}(138)$
$\mathrm{R}=\mathrm{H}:$ Sumalarins $\mathrm{C}(140)$

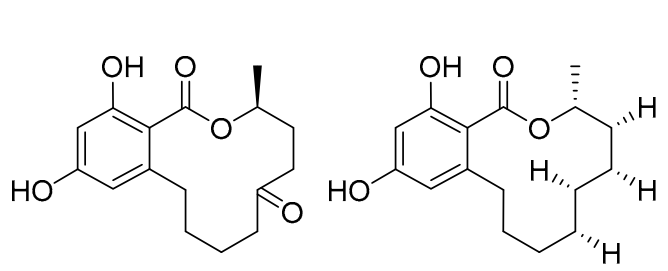<smiles>C[C@H]1CCCCCCCC(=O)Cc2cc(O)cc(O)c2C1=O</smiles>

Dehydrocurvularin (141)<smiles>C[C@H]1CCC/C=C/C(=O)c2c(O)cc(O)cc2CC(=O)O1</smiles><smiles>CC(C)=CCc1c2occc2c(C)c2ccc(=O)oc12</smiles>

Compound (142)

(3S)-6-0xo-de-0

(3R)-de-O

(3R)-nordinone (145)<smiles>Cc1cc(O)cc2c1Oc1c(C)cc(O)c(Cc3ccc(O)cc3)c1C(=O)O2</smiles>

-methyllasiodiplodin (143) -methyllasiodiplodin (144)

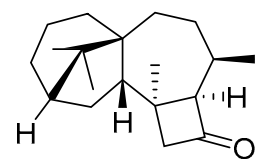

(9R,10R)-Dihydro-harzianone (147)<smiles>CC=C(C)C(=O)C(C)C1=CC(=O)C2=C(O[C@H]3CC[C@@H]4O[C@](C)(C(C)(C)O)C[C@H](O)[C@]4(C)[C@H]3C2)C1=O</smiles>

Compound (148)

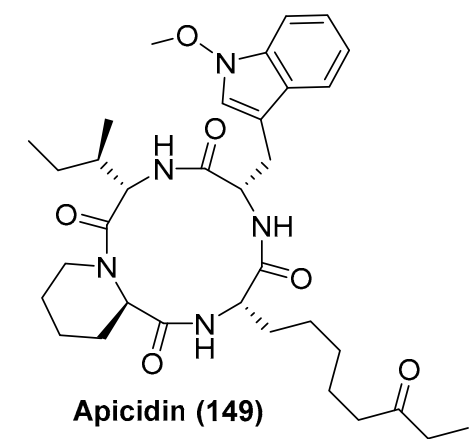

Figure 8. Structures of metabolites isolated from Hyphomycetes (131-149).

Zhang et al. [76] reported the production of a new depsidone, botryorhodine $\mathrm{H}$ (146) (Figure 8), by co-culturing mangrove endophytic fungus Trichoderma sp. 307 and Acinetobacter johnsonii B2. Compound 146 exhibited good cytotoxic activity against the MMQ and GH3 cell lines with $\mathrm{IC}_{50}$ values of 3.09 and $3.64 \mu \mathrm{M}$, respectively. 
A new harziane diterpenoid, named (9R,10R)-dihydro-harzianone (147) (Figure 8), was isolated from Trichoderma sp. Xy24, an endophytic fungus residing in the leaves, stems, and peels of the mangrove plant Xylocarpus granatum, collected in the Sanya district of Hainan province, China. Compound 147 was active against the HeLa and MCF-7 cell lines with $\mathrm{IC}_{50}$ values of $30.1 \mu \mathrm{M}$ and 30.7 $\mu \mathrm{M}$, respectively [77].

The endophytic fungus Nigrospora sp. MA75 associated with Pongamia pinnata, which led to the isolation of a new compound 2,3-didehydro-19a-hydroxy-14-epicochlioquinone B (148) (Figure 8) when grown in medium containing 3.5\% NaI. Compound 148 showed potent cytotoxicity against the MCF-7, SW1990, and SMMC7721 cell lines, with $\mathrm{IC}_{50}$ values of 4, 5, and $7 \mu \mathrm{g} / \mathrm{mL}$, respectively [78].

A known cyclic peptide, beauvericin (104) (Figure 6), was obtained from Fusarium sp. (No. DZ27) an endophytic fungus residing inside the bark of Kandelia candel from Dongzhai mangrove, Hainan, China, in the South China Sea. Compound (104) showed cytotoxic activity against the KB and $\mathrm{KBv} 200$ cell lines with $\mathrm{IC}_{50}$ values of 5.76 and $5.34 \mu \mathrm{M}$, respectively. It induces apoptosis through the mitochondrial pathway, including the decrease of relative oxygen species generation, the loss of mitochondrial membrane potential, the release of cytochrome $c$, the activation of Caspase- 9 and -3 , and the cleavage of PARP. Additionally, the regulation of Bcl-2 or Bax was not involved in the apoptosis induced by beauvericin in KB and KBv200 cells [79].

An inhibitor of histone deacetylase, Apicidin (149) (Figure 8), was isolated from Fusarium sp., an endophytic fungus associated with the leaf of mangrove Kandelia candel planted at Dongzhai Harbor on Hainan Island, China. Apicidin showed good cytotoxic activity against GLC-82 cells with the $\mathrm{IC}_{50}$ value of $6.94 \pm 0.27 \mu \mathrm{M}$. Apicidin suppressed proliferation and invasion, and induced apoptosis via the mitochondrial pathway in GLC-82 cells, including the loss of $\triangle \Psi \mathrm{m}$, the release of cytochrome c from mitochondria, the activation of caspase- 9 and -3 , and the cleavage of poly-ADP-ribose polymerase [80]. Apicidin 149, was previously isolated from the mangrove endophytic fungus ZZF42 from the South China Sea and exhibited selective in vitro cytotoxicity towards KB and KBv200 with $\mathrm{IC}_{50}$ values of less than $0.78 \mu \mathrm{g} / \mathrm{mL}$ [81].

An unusual alkaloid 2-acetyl-1,2,3,4-tetrahydro- $\beta$-carboline (150), fusamine (151), and 3-(1-aminoethylidene)-6-methyl-2H-pyran-2,4(3H)-dione (152) (Figure 9), were isolated from the culture broth of Fusarium incarnatum (HKI0504), an endophytic fungus of the mangrove plant Aegiceras corniculatum. Compound 150 exhibite weak antiproliferative activity against HUVEC and the K-562 cell line with $\mathrm{GI}_{50}$ values of 41.1 and 33.3, respectively. Compounds 151 and 152 exhibit anti-proliferative activity against HUVEC and the GI50 K-562 cell line with GI $_{50}$ values of 37.3, 37.6, and 41.1, 33.3, respectively. The compounds 150,151 and 152 displayed cytotoxic activity against HeLa cells with a $\mathrm{CC}_{50}$ value of $23.8,23.3$, and $23.8 \mu \mathrm{M}$, respectively. The standard imatinib exhibited anti-proliferative activity against HUVEC and the GI50 K-562 cell line with a GI 50 value of 18.5 and 0.17 , respectively, and cytotoxic activity against HeLa cells with a $\mathrm{CC}_{50}$ value of $65.8 \mu \mathrm{M}$ [82].

Acremonium sp., an endophytic fungus residing inside the leaves of Sonneratia caseolaris collected from Hainan, China, was the source of a dimeric anthracene derivative torrubiellin B (153) (Figure 9). Compound 153 exhibited potent cytotoxic activity against the cisplatin-sensitive cell lines Cal27, Kyse510, HCC38, A2780, MDA-MB-231with $\mathrm{IC}_{50}$ values ranging from of 0.3 to $1.5 \mu \mathrm{M}$, and against the cisplatin-resistant cell lines Cal27, Kyse510, HCC38, A2780, MDA-MB-231 with $\mathrm{IC}_{50}$ values ranging from 0.2 to $2.6 \mu \mathrm{M}$. The positive control cisplatin exhibited cytotoxic activity against the tested cell lines with $\mathrm{IC}_{50}$ values in the range of 1.5-38.1 $\mu \mathrm{M}$ [83].

Waol A (154), pestalotiopene A (155), and cytosporone E (156) (Figure 9) were obtained from the endophytic fungus Acremonium strictum, isolated from the mangrove tree Rhizophora apiculate, collected on the island of CatBa, Vietnam. Compounds 154-156 showed moderate cytotoxic activity against human cisplatin-sensitive ( $\mathrm{IC}_{50}$ values $27.1,76.2$, and $8.3 \mu \mathrm{M}$, respectively) and resistant $\mathrm{A} 2780$ cell lines ( $\mathrm{IC}_{50}$ values $12.6,30.1$, and $19.0 \mu \mathrm{M}$, respectively) [84]. 
<smiles>CC(=O)N1CCc2c([nH]c3ccccc23)C1</smiles>

2-acetyl-1,2,3,4-tetrahydro - $\beta$-carboline (150)<smiles>CC1=CC(=O)C(=C(C)NCCc2ccc(O)cc2)C(=O)O1</smiles>

Fusamine (151)<smiles>CC1=CC(=O)C(=C(C)N)C(=O)O1</smiles>

3-(1-aminoethylidene)-6-methyl -2H-pyran-2,4(3H)-dione (152)

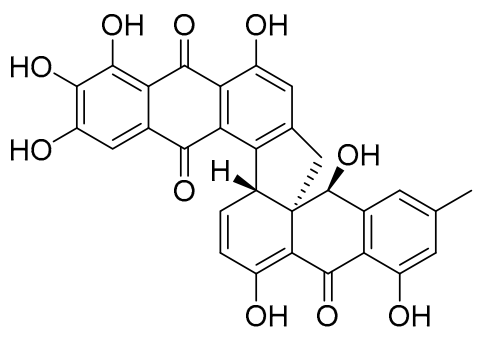<smiles>C/C=C/[C@@H]1OC(=O)C2=C[C@@H](O)[C@@H](/C=C/C)O[C@]21C</smiles>

Waol A (154)<smiles></smiles>

Torrubiellin B (153)<smiles>C=Cc1c(C)c(O)cc2c1CC[C@H](C(=C)C)[C@]2(C)COC(C)=O</smiles>

3,4-Seco-sonderianol (157)

2-(3-chloro-2,6-dihydroxy-4-methylbenzoyl) -5-hydroxy-3-methoxybenzoate(158)

Cytosporone E (156)<smiles>[R]OC(=O)C1C(=O)c2ccccc2NC1c1ccc[nH]1</smiles><smiles>O=CC(O)C=O</smiles>

Anthracene derivative (159)

$\mathbf{R}=\mathbf{H}$ :Marinamide (160) $\mathbf{R}=\mathbf{M e}:$ Methyl-marinamide (161)

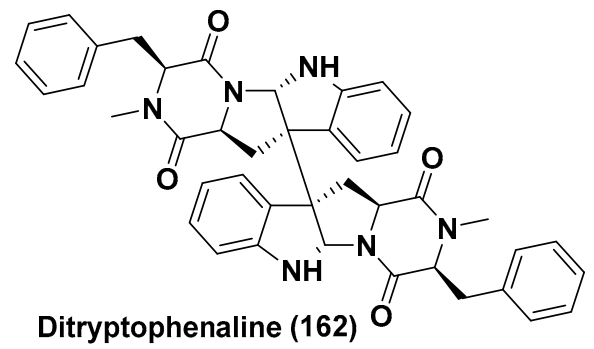<smiles>Cc1cc(O)c2c(=O)c3c(C(=O)O)cc(O)cc3oc2c1</smiles><smiles>COc1cc(C)c2c(=O)c3c(O)cc(OC)cc3oc2c1</smiles><smiles>C[C@H]1[C@@H](O)CCC(C)(C)[C@]12CC=C(C(=O)O)CC2</smiles><smiles>C[C@H]1[C@@H](O)CC[C@]2(CC=C(C(=O)O)CC2)C1(C)C</smiles>

3,8-Dihydroxy-6-methyl-9-oxo-9Hxanthene-1-carboxylic acid (163)

Lichenxanthone (164)

Merulinol C (165)

Merulinol D (166)<smiles>CC1(C)CCC(=O)[C@]2(C)OOC3(CO)CC1CC32O</smiles>

Compound (167)

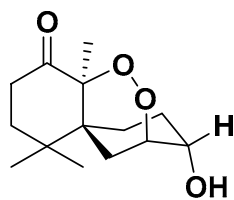

Compound (168)<smiles>CC1(C)CCC(=O)[C@]23CC4OO[C@]1(C2)C(O)C4O3</smiles>

Compound (169)

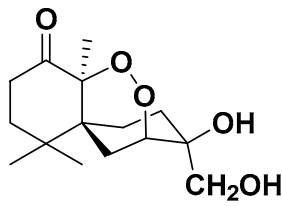

Compound (170)

Figure 9. Structures of metabolites isolated from Hyphomycetes (150-170).

The compound 3,4-seco-sonderianol (157) (Figure 9), a known diterpenoid, was obtained from the endophytic fungus J3 of Ceriops tagal, collected in Hainan province, China. Compound 157 showed cytotoxic activity against the K562, SGC-7901, and BEL-7402 cell lines with $\mathrm{IC}_{50}$ values of 9.2, 15.7, and $25.4 \mu \mathrm{g} / \mathrm{mL}$, respectively. The positive control paclitaxel displayed activity against the K562, SGC-7901 and BEL-7402 cell lines with $\mathrm{IC}_{50}$ values of 5.1, 1.6 and $6.3 \mu \mathrm{g} / \mathrm{mL}$, respectively [85]. 
The compound 2-(3-chloro-2,6-dihydroxy-4-methylbenzoyl)-5-hydroxy-3-methoxybenzoate (158) (Figure 9), was extracted from the endophytic fungus No. ZH-3 from the South China Sea. Compound 158 showed cytotoxic activity against the hepG2 cell line ( $\mathrm{IC}_{50}=25 \mu \mathrm{g} / \mathrm{mL}$ ) [86].

Mangrove endophytic fungus No.5094, which was collected in the South China Sea was the source of anthracene derivative (159) (Figure 9). Compound 159 exhibited potent activity towards the KB and KBv200 cell lines with $\mathrm{LD}_{50}$ values of 5.5 and $10.2 \mu \mathrm{M}$, respectively [87].

Marinamide (160) and methyl marinamide (161) (Figure 9) were obtained by co-cultures of two marine-derived mangrove endophytic fungi (strains Nos. 1924 and 3893) from the South China Sea coast. Their structures were elucidated using comprehensive spectra methods. Compound $\mathbf{1 6 0}$ was found to be cytotoxic with $\mathrm{IC}_{50}$ values of 7.0, $0.4,91 \mathrm{nM}$ and $0.529 \mu \mathrm{M}$, respectively against HepG2, 95-D, MGC832 and HeLa cells. For the similar cell lines, compound $\mathbf{1 6 1}$ exhibited cytotoxicity with $\mathrm{IC}_{50}$ values of 2.52, 1.54, 13.0 and $0.110 \mu \mathrm{M}$, respectively [88].

Mangrove endophytic fungus No. Gx-3a in the South China Sea was the source of ditryptophenaline (162) (Figure 9). Compound 162 exhibited potent cytotoxic activity against KB and $\mathrm{KBv} 200$ cells, with $\mathrm{LD}_{50}$ values of $8.0 \mu \mathrm{M}$ and $12.0 \mu \mathrm{M}$ [89].

The 3, 8-Dihydroxy-6-methyl-9-oxo-9H-xanthene-1-carboxylate (163) and lichenxanthone (164) (Figure 9), were isolated from the mangrove endophytic fungus No.SK7RN3G 1 from the South China Sea. Compounds 163-164 exhibited cytotoxicity against the HepG2 cell line with $\mathrm{IC}_{50}$ values of 20 and $25 \mu \mathrm{g} / \mathrm{mL}$, respectively [90].

\subsection{Compounds Produced by Basidiomycetes}

Two new chamigrane sesquiterpenes, merulinols $C$ and D $(\mathbf{1 6 5}, \mathbf{1 6 6})$ (Figure 9), were isolated from the culture of the basidiomycetous fungus XG8D, isolated from the healthy leaves of Xylocarpus granatum, collected in Samutsakorn province, Thailand. Compounds 165 and 166 selectively displayed cytotoxicity against KATO-3 cells with $\mathrm{IC}_{50}$ values of 35.0 and $25.3 \mu \mathrm{M}$, respectively [91].

Compounds 167, 168, 169 and 170 (Figure 9) were extracted from Pseudolagarobasidium acaciicola, associated with Bruguiera gymnorrhiza from Samut Sakhon province, Thailand. These compounds were evaluated for their cytotoxicity against the HuCCA-1, A549, MOLT-3, HepG2, HL-60, MDA-MB231, T47D, and HeLa cancer cell lines and normal human embryonic lung cell lines (MRC-5). Compound 167 displayed cytotoxicity against the HuCCA-1, A549, MOLT-3, HepG2, HL-60, MDA-MB231, and T47D cancer cell lines with $\mathrm{IC}_{50}$ values in the range of $0.28-37.46 \mu \mathrm{M}$ and against the MRC-5 normal cell line with an $\mathrm{IC}_{50}$ value of $17.92 \mu \mathrm{M}$. Compound 167 selectively showed activity against the HL-60 cell line with an $\mathrm{IC}_{50}$ value of $0.28 \mu \mathrm{M}$ and a selectivity index (SI) value of 64.0. Compound 168 showed activity against the A549, MOLT-3, HepG2, HL-60, MDA-MB231, T47D, HeLa and MRC-5 cells IC 50 values in the range of 12.09-170.08 $\mu \mathrm{M}$. Compounds 169 and 170 were active against the cell lines tested, $\mathrm{IC}_{50}$ $15.20-76.97 \mu \mathrm{M}$ for $\mathbf{1 6 9}$ and $\mathrm{IC}_{50} 18.31-154.51 \mu \mathrm{M}$ for $\mathbf{1 7 0}$. Compound $\mathbf{1 7 0}$ also selectively exhibited cytotoxic activity toward the HL-60 cell line ( $\left.\mathrm{IC}_{50} 18.31 \mu \mathrm{M}\right)$ with an SI value of 4.4 [92].

A new nor-chamigrane endoperoxide, 3-epi-Steperoxide A (171), along with the known sesquiterpenes steperoxide A (172), merulin B (173), and merulin C (174) (Figure 10) were isolated from Pseudolagarobasidium acaciicola, an endophyte residing inside the mangrove plant Bruguiera gymnorrhiza. Compounds $\mathbf{1 7 1}$ and $\mathbf{1 7 2}$ showed strong cytotoxic activity with $\mathrm{IC}_{50}$ ranges of $0.68-3.71$ and 0.67-5.25 $\mu \mathrm{g} / \mathrm{mL}$, respectively, against MOLT-3, HuCCA-1, A549, HepG2, HL-60, MDA-MB-231, T47D, and HeLa cells. Compound 173 exhibited weak activity against MOLT-3, A549, HepG2, HL-60, MDA-MB-231 and T47D cells with an $\mathrm{IC}_{50}$ ranging from $11.94-49.08 \mu \mathrm{g} / \mathrm{mL}$, but was inactive toward HuCCA-1 and HeLa cells at $50 \mu \mathrm{g} / \mathrm{mL}$. Compound 174 showed the most potent cytotoxic activity against HL60 cancer cells, with an $\mathrm{IC}_{50}$ value of $0.08 \mu \mathrm{g} / \mathrm{mL}$, whereas it displayed activity toward the MOLT-3, HuCCA-1, A549, HepG2, MDA-MB-231, T47D, and HeLa cell lines with an $\mathrm{IC}_{50}$ range of $0.19-3.75 \mu \mathrm{g} / \mathrm{mL}$ [93]. 


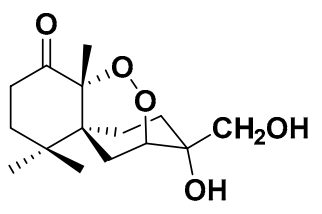

Compound (171)

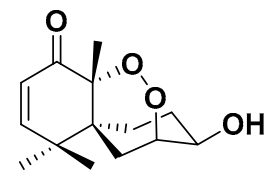

Steperoxide A (172)

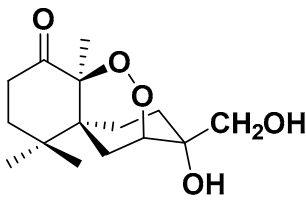

Merulin B (173)

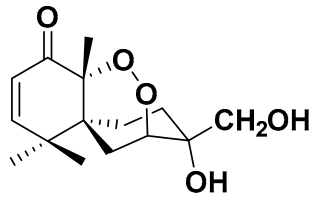

Merulin C (174)

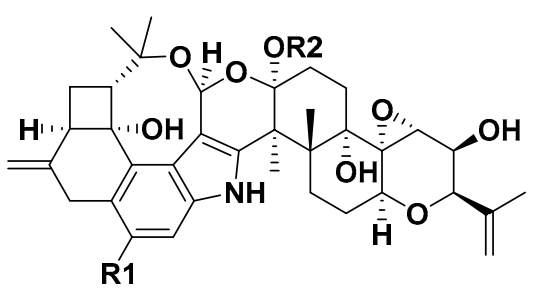

A: $\mathrm{R}_{\mathbf{1}}=\mathrm{Cl}, \mathrm{R}_{\mathbf{2}}=\mathrm{H}$

B: $\mathbf{R}_{1}=\mathrm{Cl}, \mathrm{R}_{\mathbf{2}}=\mathrm{CH}_{3}$

Rhizovarins A, B $(175,176)$

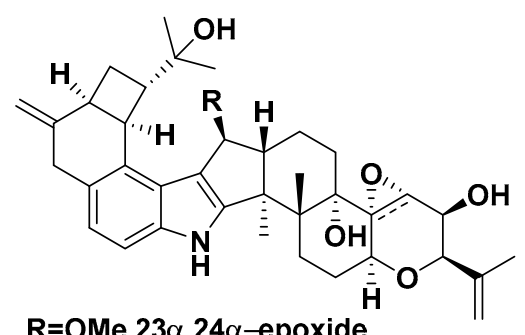

$\mathrm{R}=\mathrm{OMe}, 23 \alpha, 24 \alpha$-epoxide

Rhizovarin E (177)

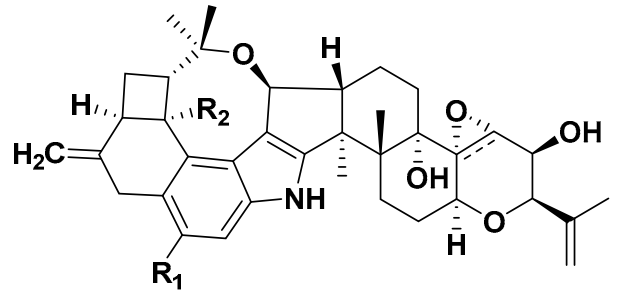

$\mathrm{R} 1=\mathrm{Cl}, \mathrm{R} 2=\mathrm{OH}, 23 \alpha, 24 \alpha$-epoxide : Penitrem $A,(178)$

R1=Cl, R2=H, 23 $\alpha, 24 \alpha$-epoxide : Penitrem B (179)

R1=Cl, R2=H, 23 $\alpha, 24 \alpha$-epoxide :Penitrem F (180)

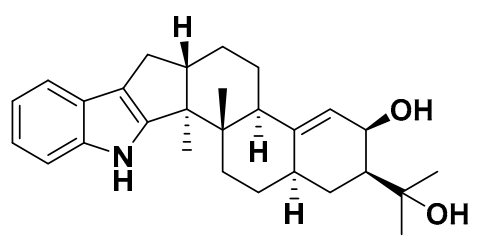

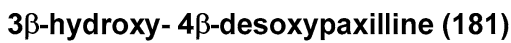

Figure 10. Structures of metabolites isolated from Basidiomycetes (171-174) and from Zygomycetes (175-181).

\subsection{Compounds Produced by Zygomycetes}

The rhizovarins A, B, E (175-177), penitrems A, C, F (178-180) and 3 $\beta$-hydroxy-4 $\beta$-desoxypaxilline (181) (Figure 10) were obtained from Mucor irregularis QEN-189, an endophytic fungus residing inside the inner tissue of Rhizophora stylosa, collected in Hainan Island, China. Compounds 175-181 showed cytotoxicity against the human A-549 cell lines with $\mathrm{IC}_{50}$ values of $11.5,6.3,9.2,8.4,8.0,8.2$, and $4.6 \mu \mathrm{M}$, while compounds $\mathbf{1 7 5}, \mathbf{1 7 6}, \mathbf{1 7 8}-\mathbf{1 8 1}$ were cytotoxic against the human HL-60 cell lines with $\mathrm{IC}_{50}$ values of 9.6, 5.0, 7.0, 4.7, 3.3 and $2.6 \mu \mathrm{M}$, respectively. Adriamycin, a positive control, exhibited activity against A-549 and HL-60 cell lines with $\mathrm{IC}_{50}$ values of 0.30 and $0.06 \mu \mathrm{M}$, respectively [94]. 
Table 1. Novel anticancer bioactive compounds reported from mangrove fungi.

\begin{tabular}{|c|c|c|c|c|c|c|c|}
\hline $\begin{array}{l}\text { Sr. } \\
\text { No. }\end{array}$ & Fungus & Host Plant(s) & $\begin{array}{c}\text { Plant Part or Tissue } \\
\text { Locality of } \\
\text { Host Plants }\end{array}$ & Compounds Isolated & Cell Line & $\mathrm{IC}_{50 /} \mathrm{EC}_{50} /$ Inhibition & Refs. \\
\hline \multicolumn{8}{|c|}{ Compounds Produced by Coelomycetes } \\
\hline \multirow[b]{2}{*}{1} & \multirow[b]{2}{*}{ Pestalotiopsis sp. } & \multirow[b]{2}{*}{ Rhizophora mucronata } & \multirow[b]{2}{*}{ Not reported } & Demethylincisterol A3 (1) & HeLa, A549 and HepG & $\begin{array}{c}\text { In the range of } 0.17 \text { to } \\
14.16 \mathrm{nM}\end{array}$ & \multirow[b]{2}{*}{ [16] } \\
\hline & & & & $\begin{array}{l}\text { Ergosta-5,7,22-trien-3-ol (2), } \\
\text { stigmastan-3-one (3), } \\
\text { stigmast-4-en-3-one (4), } \\
\text { stigmast4-en-6-ol-3-one (5), } \\
\text { flufuran (6) }\end{array}$ & HeLa, A549 and HepG & $\begin{array}{l}\text { In the range of } \\
11.44-102.11 \mu \mathrm{M}\end{array}$ & \\
\hline \multirow[t]{2}{*}{2} & \multirow[t]{2}{*}{ Pestalotiopsis microspore } & \multirow[t]{2}{*}{ Drepanocarpus lunatus } & \multirow[t]{2}{*}{ Cameroon } & $\begin{array}{c}\text { Compound (7) } \\
\text { Pestalotioprolide D-F (8-10) }\end{array}$ & L5178Y & $0.7,5.6,3.4$, and $3.9 \mu \mathrm{M}$ & \multirow[t]{2}{*}{ [17] } \\
\hline & & & & Pestalotioprolide E (9) & A2780 & $1.2 \mu \mathrm{M}$ & \\
\hline 3 & Pestalotiopsis clavispora & Rhizophora harrisonii & Port Harcourt, Nigeria & Pestalpolyol I (11) & L5178Y & $4.10 \mu \mathrm{M}$ & [18] \\
\hline 4 & Pestalotiopsis vaccinia & Kandelia candel & China & Pestalamine A (12) & MCF-7, HeLa, and HepG2 & $40.3,22.0$, and $32.8 \mu \mathrm{M}$ & [19] \\
\hline 5 & $\begin{array}{l}\text { Phoma sp. } \\
\text { OUCMDZ-1847 }\end{array}$ & $\begin{array}{l}\text { Fruit sample of Kandelia } \\
\text { candel }\end{array}$ & $\begin{array}{l}\text { Wenchang, Hainan } \\
\text { Province, China }\end{array}$ & $\begin{array}{l}\text { Phomazines B (13), } \\
\text { epicorazine A (14), } \\
\text { epicorazine B (15), } \\
\text { epicorazine C (16), } \\
\text { exserohilone A (17) }\end{array}$ & $\begin{array}{l}\text { HL-60, HCT-116, K562, } \\
\text { MGC-803, and A549 Cells }\end{array}$ & $\begin{array}{c}\text { In the range } 0.05 \text { to } \\
8.5 \mu \mathrm{M}\end{array}$ & [20] \\
\hline 6 & Phomopsis sp. & & Zhanjiang, China & Cytochalasin H (18) & A549 cells & $\begin{array}{l}\text { Arrested A549 cells at } \\
\text { the G2/M phase, } \\
\text { inhibited the migration } \\
\text { ability of A549 cells in a } \\
\text { dose-dependent manner }\end{array}$ & [21] \\
\hline 7 & $\begin{array}{l}\text { Phomopsis spp. xy } 21 \\
\text { and xy } 22\end{array}$ & $\begin{array}{l}\text { Leaves Xylocarpus } \\
\text { granatum }\end{array}$ & $\begin{array}{l}\text { Trang Province, } \\
\text { Thailand }\end{array}$ & Phomopsichalasin G (19) & $\begin{array}{l}\text { HCT-8, HCT-8/T, A549, } \\
\text { MDA-MB-231, and A2780 } \\
\text { cancer Cells }\end{array}$ & $\begin{array}{c}7.5,8.6,6.4,3.4 \text {, and } \\
7.1 \mu \mathrm{M}\end{array}$ & [22] \\
\hline 8 & $\begin{array}{c}\text { Phomopsis longicolla } \\
\text { HL-2232 }\end{array}$ & $\begin{array}{l}\text { Bruguiera sexangula var. } \\
\text { rhynchopetala }\end{array}$ & & $\begin{array}{c}\text { 6-aminopurine-9-carboxylic } \\
\text { acid Me ester (20), } \\
\text { uridine (21) }\end{array}$ & $\begin{array}{l}\text { B16F10, A549, HL-60 and } \\
\text { MCF-7 Cells }\end{array}$ & 14.9 and $8.6 \mu \mathrm{M}$ & [23] \\
\hline
\end{tabular}


Table 1. Cont

\begin{tabular}{|c|c|c|c|c|c|c|c|}
\hline $\begin{array}{l}\text { Sr. } \\
\text { No. }\end{array}$ & Fungus & Host Plant(s) & $\begin{array}{l}\text { Plant Part or Tissue } \\
\text { Locality of } \\
\text { Host Plants }\end{array}$ & Compounds Isolated & Cell Line & $\mathrm{IC}_{50 /} \mathrm{EC}_{50} /$ Inhibition & Refs. \\
\hline \multicolumn{8}{|c|}{ Compounds Produced by Coelomycetes } \\
\hline \multirow{4}{*}{9} & \multirow{4}{*}{$\begin{array}{l}\text { Phomopsis sp. } \\
\text { HNY29-2B }\end{array}$} & \multirow{4}{*}{$\begin{array}{l}\text { Branch of Acanthus } \\
\text { llicifolius }\end{array}$} & \multirow{4}{*}{$\begin{array}{c}\text { South China Sea, } \\
\text { Hainan province, } \\
\text { China }\end{array}$} & Dicerandrol A (22) & $\begin{array}{l}\text { MDA-MB-435, HCT-116, Calu-3 } \\
\text { and Huh7 Cells }\end{array}$ & $\begin{array}{c}3.03,2.64,1.76 \text { and } \\
4.19 \mu \mathrm{M}\end{array}$ & \multirow{4}{*}{ [24] } \\
\hline & & & & $\begin{array}{l}\text { Dicerandrol B (23), } \\
\text { Penexanthone A (26) }\end{array}$ & $\begin{array}{l}\text { MDA-MB-435, HCT-116 and } \\
\text { Calu-3 }\end{array}$ & $<10 \mu \mathrm{M}$ & \\
\hline & & & & Dicerandrol C (24) & $\begin{array}{l}\text { MDA-MB-435, HCT-116, } \\
\text { Calu-3, MCF-10A Cells }\end{array}$ & $\begin{array}{c}44.10,42.63,36.52 \text {, and } \\
33.05 \mu \mathrm{M}\end{array}$ & \\
\hline & & & & $\begin{array}{c}\text { diacetyl phomoxanthone } \\
\text { B (25) }\end{array}$ & $\begin{array}{l}\text { MDA-MB-435, HCT-116, } \\
\text { Calu-3, Huh7 Cells }\end{array}$ & $\begin{array}{c}14.40,7.12,4.14 \text { and } \\
29.20 \mu \mathrm{M}\end{array}$ & \\
\hline 10 & Phomopsis sp. (ZH76) & Excoecaria agallocha & $\begin{array}{l}\text { Dong Sai, South China } \\
\text { Sea coast }\end{array}$ & $\begin{array}{l}\text { 3-O-(6-O- } \alpha \text {-L-arabinopyranosyl)- } \\
\beta \text {-D-glucopyranosyl-1,4- } \\
\text { dimethoxyxanthone (27) }\end{array}$ & HEp-2 and HepG2 & 9 and $16 \mu \mathrm{M}$ & [25] \\
\hline \multirow[b]{2}{*}{11} & \multirow[b]{2}{*}{$\begin{array}{c}\text { Diaporthe sp. SCSIO } \\
41011\end{array}$} & \multirow[b]{2}{*}{ Rhizophora stylosa } & \multirow[b]{2}{*}{$\begin{array}{l}\text { Sanya city, Hainan } \\
\text { Province, China }\end{array}$} & Isochromophilone D (28) & 786-O cells & $8.9 \mu \mathrm{M}$ & \multirow[b]{2}{*}{ [26] } \\
\hline & & & & epi-Isochromophilone II (29) & $\begin{array}{l}\text { ACHN, OS-RC-2, and 786-O } \\
\text { cells, }\end{array}$ & $\begin{array}{c}\text { In the range of } 3.0 \text { to } \\
4.4 \mu \mathrm{M} \text {, Sorafenib } \\
(3.4 \text { to } 7.0 \mu \mathrm{M})\end{array}$ & \\
\hline \multirow[t]{2}{*}{12} & \multirow{2}{*}{$\begin{array}{l}\text { Diaporthe phaseolorum } \\
\text { SKS019 }\end{array}$} & \multirow{2}{*}{$\begin{array}{c}\text { Branches of Acanthus } \\
\text { ilicifolius }\end{array}$} & \multirow{2}{*}{$\begin{array}{l}\text { Shankou, Guangxi } \\
\text { province, China }\end{array}$} & 5-deoxybostrycoidin (30) & $\begin{array}{l}\text { MDA-MB-435 and NCI-H460 } \\
\text { cancer cells }\end{array}$ & 5.32 and $6.57 \mu \mathrm{M}$ & \multirow[t]{2}{*}{ [27] } \\
\hline & & & & Fusaristatin A (31) & MDA-MB-435 cancer cells & $8.15 \mu \mathrm{M}$ & \\
\hline 13 & Phomosis sp. A818 & $\begin{array}{l}\text { Foliage of Kandelia } \\
\text { candel }\end{array}$ & Fujian Province, China & $\begin{array}{c}\text { Mycoepoxydiene (32), } \\
\text { deacetylmycoepoxydiene (33) }\end{array}$ & MDA-MB-435 & 7.85 and $14.61 \mu \mathrm{M}$ & [28] \\
\hline 14 & Phomosis sp. A818 & $\begin{array}{l}\text { Foliage of Kandelia } \\
\text { candel }\end{array}$ & Fujian Province, China & Mycoepoxydiene (32) & $\begin{array}{l}\text { Suppress antigen-stimulated } \\
\text { degranulation and cytokine } \\
\text { production in mast cells and } \\
\text { IgE-mediated passive } \\
\text { cutaneous anaphylaxis in mice }\end{array}$ & & [29] \\
\hline 15 & $\begin{array}{l}\text { Sarocladium kiliense } \\
\text { HDN11-84 }\end{array}$ & $\begin{array}{l}\text { rhizosphere soil of } \\
\text { Thespesia populnea, }\end{array}$ & $\begin{array}{l}\text { Guangxi Province, } \\
\text { China }\end{array}$ & Saroclazine B (34) & HeLa Cells & $4.2 \mu \mathrm{M}$ & [30] \\
\hline
\end{tabular}


Table 1. Cont

\begin{tabular}{|c|c|c|c|c|c|c|c|}
\hline $\begin{array}{l}\text { Sr. } \\
\text { No. }\end{array}$ & Fungus & Host Plant(s) & $\begin{array}{l}\text { Plant Part or Tissue } \\
\text { Locality of } \\
\text { Host Plants }\end{array}$ & Compounds Isolated & Cell Line & $\mathrm{IC}_{50} / \mathrm{EC}_{50} /$ Inhibition & Refs. \\
\hline \multicolumn{8}{|c|}{ Compounds Produced by Ascomycetes } \\
\hline 16 & Annulohypoxylon sp. & Rhizophora racemosa & Cameroon & Daldinone I (35) & Ramos and Jurkat J16 & $\begin{array}{c}6.6 \text { and } 14.1 \mu \mathrm{M}, \\
\text { Potently blocks } \\
\text { autophagy, a potential } \\
\text { pro-survival pathway } \\
\text { for cancer cells }\end{array}$ & [31] \\
\hline \multirow[b]{2}{*}{17} & \multirow[b]{2}{*}{ Eurotium rubrum } & \multirow[b]{2}{*}{ Suaeda salsa } & \multirow[b]{2}{*}{$\begin{array}{l}\text { "BoHai" seaside, } \\
\text { China }\end{array}$} & \multirow[b]{2}{*}{ Rubrumol (36) } & $\begin{array}{l}\text { A549, MDA-MB-231, PANC-1 } \\
\text { and HepG2 }\end{array}$ & Cytotoxic & \multirow[b]{2}{*}{ [32] } \\
\hline & & & & & Topo I & $\begin{array}{c}\text { Relaxation activity The } \\
\text { band backward shifting } \\
\text { and trailing of rubrumol } \\
\text { (36) was observed at } 100 \text {, } \\
50,10,5 \text { and } 1 \mu \mathrm{M}\end{array}$ & \\
\hline 18 & Eutypella sp. 1-15 & $\begin{array}{l}\text { Soil of mangrove } \\
\text { rhizosphere in Jimei, } \\
\text { Fujian Province, China }\end{array}$ & Not reported & $\begin{array}{c}\text { 13-Hydroxy-3,8,7(11)- } \\
\text { eudesmatrien-12,8-olide (37) }\end{array}$ & JEKO-1 and HepG2 & 8.4 and $28.5 \mu \mathrm{M}$ & [33] \\
\hline \multirow[t]{2}{*}{19} & \multirow[t]{2}{*}{$\begin{array}{c}\text { Rhytidhysteron rufulum } \\
\text { AS21B }\end{array}$} & \multirow[t]{2}{*}{$\begin{array}{l}\text { Leaves of Azima } \\
\text { sarmentosa }\end{array}$} & \multirow[t]{2}{*}{$\begin{array}{l}\text { Samutsakhon } \\
\text { province, Thailand }\end{array}$} & $\begin{array}{c}\text { Rhytidenones G (38), H (39)), } \\
\text { deoxypreussomerin B (40), } \\
\text { palmarumycin CP17 (41), } \\
\text { 1-oxo-1,4-dihydronapthalene- } \\
\text { 4-spiro-20-naptho[400-hydroxy- } \\
\text { 100,800-de][10,30]-dioxine } \\
\text { (42), preussomerin EG4 (43), } \\
\text { rhytidenone E (44), } \\
\text { rhytidenone F (45), } \\
\text { palmarumycin C5 (46), and } \\
\text { 4,8-dihydroxy-3,4- } \\
\text { dihydronaphthalen- } \\
\text { 1(2H)-one (47) }\end{array}$ & Ramos lymphoma & $\begin{array}{c}\text { 17.98, 0.018, 18.00, 33.1, } \\
\text { 15, 82.9, 0.461, 0.048, } \\
31.7 \text { and } 23.1 \mu \mathrm{M} \\
\text { (Ibrutinib } 28.7 \mu \mathrm{M} \text { ) }\end{array}$ & \multirow[t]{2}{*}{ [34] } \\
\hline & & & & $\begin{array}{l}\text { Compounds (38), (39), (44), } \\
\text { (45), and (47) }\end{array}$ & H1975 Cell & $\begin{array}{c}7.3,0.252,10.24,1.17 \\
\text { and } 50 \mu \mathrm{M} \\
(\text { afatinib } 1.97 \mu \mathrm{M})\end{array}$ & \\
\hline
\end{tabular}


Table 1. Cont

\begin{tabular}{|c|c|c|c|c|c|c|c|}
\hline $\begin{array}{l}\text { Sr. } \\
\text { No. }\end{array}$ & Fungus & Host Plant(s) & $\begin{array}{l}\text { Plant Part or Tissue } \\
\text { Locality of } \\
\text { Host Plants }\end{array}$ & Compounds Isolated & Cell Line & $\mathrm{IC}_{50} / \mathrm{EC}_{50} /$ Inhibition & Refs. \\
\hline \multicolumn{8}{|c|}{ Compounds Produced by Ascomycetes } \\
\hline 20 & Lasiodiplodia sp. 318\# & Excoecaria agallocha & $\begin{array}{c}\text { Guangdong Province, } \\
\text { China }\end{array}$ & $\begin{array}{c}\text { 2,4-Dihydroxy-6-nonylbenzoate } \\
\text { (48) }\end{array}$ & MMQ and GH3 Cells & 5.2 and $13.0 \mu \mathrm{M}$ & [35] \\
\hline 21 & Lasiodiplodia sp. 318\# & Excoecaria agallocha & $\begin{array}{l}\text { Guangdong Province, } \\
\text { China }\end{array}$ & $\begin{array}{c}\text { Ethyl-2,4-dihydroxy-6- } \\
\text { (80-hydroxynonyl)-benzoate } \\
(49)\end{array}$ & $\begin{array}{c}\text { MDA-MB-435, HepG2, } \\
\text { HCT-116, A549 and leukaemia } \\
\text { THP1 Cells }\end{array}$ & $\begin{array}{c}0.13,12.50,11.92,13.31 \\
\quad \text { and } 39.74 \mu \mathrm{M}\end{array}$ & [36] \\
\hline \multirow[b]{2}{*}{22} & \multirow[b]{2}{*}{$\begin{array}{l}\text { Lasiodiplodia } \\
\text { theobromae ZJ-HQ1 }\end{array}$} & \multirow[b]{2}{*}{ Acanthus ilicifolius } & \multirow[b]{2}{*}{$\begin{array}{l}\text { Guangdong Province, } \\
\text { China }\end{array}$} & $\begin{array}{l}\text { Chloropreussomerins A and } \\
\text { B }(50,51) \text { Preussomerin D }(56)\end{array}$ & A549 and MCF-7 & $\begin{array}{l}\text { In the range of } \\
5.9-8.9 \mu \mathrm{M}\end{array}$ & \multirow[b]{2}{*}{ [37] } \\
\hline & & & & $\begin{array}{l}\text { Preussomerin K (52), } \\
\text { Preussomerin H (53), } \\
\text { Preussomerin G (54), } \\
\text { Preussomerin F (55), }\end{array}$ & A549, HepG2, MCF-7 & $\begin{array}{l}\text { In the range of } \\
2.5-9.4 \mu \mathrm{M}\end{array}$ & \\
\hline \multirow[t]{2}{*}{23} & \multirow{2}{*}{$\begin{array}{c}\text { Rhytidhysteron rufulum } \\
\text { BG2-Y }\end{array}$} & \multirow{2}{*}{$\begin{array}{l}\text { Leaves of Bruguiera } \\
\text { gymnorrhiza }\end{array}$} & \multirow{2}{*}{$\begin{array}{l}\text { Pak Nam Pran, } \\
\text { Prachuab Kiri Khan } \\
\text { Province, Thailand }\end{array}$} & $\begin{array}{l}\text { Rhytidchromone A (57), } \\
\text { B (58), C (59), and E (60) }\end{array}$ & Kato-3 Cells & $\begin{array}{c}\text { In the range of } \\
16.0-23.3 \mu \mathrm{M}\end{array}$ & \multirow[t]{2}{*}[38]{} \\
\hline & & & & & MCF-7 cells & $19.3-17.7 \mu \mathrm{M}$ & \\
\hline 24 & $\begin{array}{l}\text { Campylocarpon sp. } \\
\text { HDN13-307 }\end{array}$ & $\begin{array}{l}\text { Root of Sonneratia } \\
\text { caseolaris }\end{array}$ & China & $\begin{array}{l}\text { Campyridone D (61), and } \\
\text { ilicicolin } \mathrm{H}(\mathbf{6 2})\end{array}$ & $\mathrm{HeLa}$ & 8.8 and $4.7 \mu \mathrm{M}$ & [39] \\
\hline \multirow[t]{2}{*}{25} & \multirow[t]{2}{*}{$\begin{array}{l}\text { Stemphylium } \\
\text { globuliferum }\end{array}$} & \multirow[t]{2}{*}{ Avicennia marina } & \multirow[t]{2}{*}{ Hurghada, Egypt } & $\begin{array}{c}\text { Dihydroaltersolanol C (63), } \\
\text { Altersolanol A (64), } \\
\text { Altersolanol B (65), } \\
\text { Alterporriol E (67) }\end{array}$ & L5178Y & $\begin{array}{c}3.4,2.53,3.78 \text { and } \\
6.9 \mu \mathrm{M}\end{array}$ & \multirow[t]{2}{*}{ [40-42] } \\
\hline & & & & Altersolanol N (66) & L5178Y & $\begin{array}{l}\text { Low micromolar range } \\
\quad(\% \text { growth }-1.4)\end{array}$ & \\
\hline \multirow{4}{*}{26} & \multirow{4}{*}{$\begin{array}{l}\text { Paradictyoarthrinium } \\
\text { diffractum BCC } 8704\end{array}$} & \multirow{4}{*}{$\begin{array}{l}\text { Associated with } \\
\text { mangrove wood }\end{array}$} & \multirow{4}{*}{$\begin{array}{l}\text { Laem SonNational } \\
\text { Park, Ranong } \\
\text { Province, Thailand }\end{array}$} & Paradictyoarthrins A (68) & $\begin{array}{l}\text { KB, MCF-7, NCI-H187, Vero } \\
\text { Cells, KB, MCF-7, NCI-H187, } \\
\text { Vero Cells }\end{array}$ & $\begin{array}{l}\text { In the range of } 23-31 \\
\qquad \mathrm{~g} / \mathrm{mL}\end{array}$ & \multirow{4}{*}[46]{} \\
\hline & & & & Paradictyoarthrin B (69) & $\begin{array}{l}\text { KB, MCF-7, NCI-H187, } \\
\text { Vero Cells }\end{array}$ & $\begin{array}{c}3.1,3.8,9.5, \text { and } 5.6 \\
\mu \mathrm{g} / \mathrm{mL}\end{array}$ & \\
\hline & & & & $\begin{array}{l}\text { Preussomerin C (70), ymf } \\
1029 \text { C (71) and altenusin (72) }\end{array}$ & $\begin{array}{l}\text { KB, MCF-7, NCI-H187, } \\
\text { Vero Cells }\end{array}$ & $\begin{array}{l}\text { Moderate to poor } \\
\text { activity }\end{array}$ & \\
\hline & & & & ymf 1029C (71) & NCI-H187 cells & $5.0 \mu \mathrm{g} / \mathrm{mL}$ & \\
\hline
\end{tabular}


Table 1. Cont

\begin{tabular}{|c|c|c|c|c|c|c|c|}
\hline $\begin{array}{l}\text { Sr. } \\
\text { No. }\end{array}$ & Fungus & Host Plant(s) & $\begin{array}{l}\text { Plant Part or Tissue } \\
\text { Locality of } \\
\text { Host Plants }\end{array}$ & Compounds Isolated & Cell Line & $\mathrm{IC}_{50 /} \mathrm{EC}_{50} /$ Inhibition & Refs. \\
\hline \multicolumn{8}{|c|}{ Compounds Produced by Ascomycetes } \\
\hline 27 & $\begin{array}{l}\text { Halorosellinia sp. } \\
\quad \text { (No. 1403) }\end{array}$ & - & South China Sea & SZ-685C (73) & NFPA, MMQ and RPC cells & $\begin{array}{c}18.76,14.51 \text {, and } \\
56.09 \mu \mathrm{M}\end{array}$ & [47] \\
\hline 28 & Dothiorella sp. & Aegiceras corniculatum & Fujian Province, China & $\begin{array}{l}\text { Dothiorelone F (74), } \\
\text { Dothiorelone G (75) }\end{array}$ & Raji cancer & $2 \mu \mathrm{g} / \mathrm{mL}$ & [49] \\
\hline \multirow[t]{2}{*}{29} & \multirow[t]{2}{*}{ Rhytidhysteron sp. } & \multirow[t]{2}{*}{$\begin{array}{l}\text { Leaves of Azima } \\
\text { sarmentosa }\end{array}$} & \multirow[t]{2}{*}{$\begin{array}{c}\text { Samutsakhon } \\
\text { province, Thailand }\end{array}$} & $\begin{array}{c}\text { Rhytidones B-C (76, 77), } \\
\text { MK3018 (78), palmarumycin } \\
\text { CR1 (79) }\end{array}$ & MCF-7 and CaSki Cells & $\begin{array}{l}\text { In the range of } 14.47 \text { and } \\
\qquad 25.59 \mu \mathrm{M}\end{array}$ & \multirow[t]{2}{*}{ [50] } \\
\hline & & & & Rhytidones B (76) & CaSki & $22.81 \mu \mathrm{M}$ & \\
\hline \multirow{2}{*}{30} & \multirow{2}{*}{ Sporothrix sp. } & \multirow{2}{*}{ Bark, Kandelia candel } & \multirow{2}{*}{ South China Sea } & Sporothrin A (80) & Inhibition of AChE in vitro & $1.05 \mu \mathrm{M}$ & \multirow{2}{*}{ [51] } \\
\hline & & & & $\begin{array}{l}\text { sporothrin B (81), sporothrin } \\
\text { C (82), diaporthin (83) }\end{array}$ & HepG2 & 20,23 , and $23 \mu \mathrm{g} / \mathrm{mL}$ & \\
\hline 31 & Eurotium rubrum & $\begin{array}{l}\text { Semi-mangrove plant } \\
\text { Hibiscus tiliaceus }\end{array}$ & Hainan Island, China & $\begin{array}{c}\text { 12-demethyl-12-oxo- } \\
\text { eurotechinulin B (84), } \\
\text { 9-dehydroxyeurotinone (85), } \\
\text { variecolorin G (86), alkaloid } \\
\text { E-7 (87), and emodin (88) }\end{array}$ & $\begin{array}{c}\text { HepG2, MCF-7, SW1990, } \\
\text { HepG2, NCI-H460, SMMC7721, } \\
\text { HeLa, and Du145 }\end{array}$ & $\begin{array}{l}\text { In the range of } \\
15-30 \mu \mathrm{g} / \mathrm{mL}\end{array}$ & [52] \\
\hline \multirow[t]{2}{*}{32} & \multirow[t]{2}{*}{ Bionectria ochroleuca } & \multirow{2}{*}{$\begin{array}{l}\text { Inner leaf tissues of the } \\
\text { plant Sonneratia } \\
\text { caseolaris }\end{array}$} & \multirow[t]{2}{*}{ Hainan island, China } & $\begin{array}{c}\text { Pullularins E (89), F (90), } \\
\text { pullularins A (91), and C (92) }\end{array}$ & L5178Y & $\begin{array}{l}\mathrm{EC}_{50} \text { values In the range } \\
\text { of } 0.1 \text { and } 6.7 \mu \mathrm{g} / \mathrm{mL}\end{array}$ & \multirow[t]{2}{*}{ [53] } \\
\hline & & & & verticillin $\mathrm{D}(\mathbf{9 3})$ & L5178Y & $<0.1 \mu \mathrm{g} / \mathrm{mL}$ & \\
\hline 33 & $\begin{array}{l}\text { Aspergillus sp. } \\
\text { HN15-5D }\end{array}$ & $\begin{array}{l}\text { Leaves, Acanthus } \\
\text { ilicifolius }\end{array}$ & Hainan Island, China & $\begin{array}{c}\text { Aspergisocoumrins A-B } \\
(\mathbf{9 4 - 9 5 )}\end{array}$ & MDA-MB-435 & 5.08 and $4.98 \mu \mathrm{M}$ & [54] \\
\hline \multirow{2}{*}{34} & \multirow{2}{*}{$\begin{array}{l}\text { Aspergillus niger } \\
\text { MA-132 }\end{array}$} & \multirow{2}{*}{ Avicennia marina } & \multirow{2}{*}{ Hainan, China } & $\begin{array}{l}\text { Nigerasterol A (96) } \\
\text { Nigerasterol B (97) }\end{array}$ & HL60 & $0.30 \mu \mathrm{M}, 1.50 \mu \mathrm{M}$ & \multirow{2}{*}{ [55] } \\
\hline & & & & $\begin{array}{l}\text { Nigerasterol A (96) } \\
\text { Nigerasterol B (97) }\end{array}$ & A549 & 1.82 and $5.41 \mu \mathrm{M}$ & \\
\hline 35 & $\begin{array}{l}\text { Aspergillus nidulans } \\
\text { MA-143 }\end{array}$ & $\begin{array}{l}\text { Leaves, Rhizophora } \\
\text { stylosa }\end{array}$ & & $\begin{array}{l}\text { Aniquinazolines A-D } \\
\qquad \mathbf{( 9 8 - 1 0 1 )}\end{array}$ & Brine shrimp & $\begin{array}{c}\mathrm{LD}_{50} 1.27,2.11,4.95 \text { and } \\
3.42 \mu \mathrm{M},(\text { Colchicine } \\
\text { LD }_{50} 88.4 \mu \mathrm{M}\end{array}$ & [56] \\
\hline
\end{tabular}


Table 1. Cont

\begin{tabular}{|c|c|c|c|c|c|c|c|}
\hline $\begin{array}{l}\text { Sr. } \\
\text { No. }\end{array}$ & Fungus & Host Plant(s) & $\begin{array}{l}\text { Plant Part or Tissue } \\
\text { Locality of } \\
\text { Host Plants }\end{array}$ & Compounds Isolated & Cell Line & $\mathrm{IC}_{50 /} \mathrm{EC}_{50} /$ Inhibition & Refs. \\
\hline \multicolumn{8}{|c|}{ Compounds Produced by Ascomycetes } \\
\hline \multirow[t]{2}{*}{36} & \multirow[t]{2}{*}{$\begin{array}{l}\text { Aspergillus terreus } \\
\text { (No. GX7-3B) }\end{array}$} & \multirow[t]{2}{*}{$\begin{array}{l}\text { Branch of Bruguiera } \\
\text { gymnoihiza (Linn.) }\end{array}$} & \multirow[t]{2}{*}{ South China Sea } & $\begin{array}{c}3 \beta, 5 \alpha \text {-dihydroxy-(22E,24R)- } \\
\text { ergosta-7,22-dien-6-one (102), } \\
\text { Beauvericin (104) }\end{array}$ & MCF-7, A549, HeLa and KB & $\begin{array}{l}4.98 \text { and } 2.02,1.95 \text { and } \\
0.82,0.68 \text { and } 1.14,1.50 \\
\text { and } 1.10 \mu \mathrm{M}\end{array}$ & \multirow[t]{2}{*}{ [57] } \\
\hline & & & & $\begin{array}{l}3 \beta, 5 \alpha, 14 \alpha \text {-trihydroxy-(22E,24R)- } \\
\text { ergosta-7, 22-dien-6-one (103) }\end{array}$ & MCF-7, A549, HeLa and KB & $25.4,27.1,24.4,19.4 \mu \mathrm{M}$ & \\
\hline \multirow{2}{*}{37} & \multirow{2}{*}{$\begin{array}{l}\text { Aspergillus terreus } \\
\text { (No. GX7-3B) }\end{array}$} & \multirow{2}{*}{$\begin{array}{l}\text { Branch of Bruguiera } \\
\text { gymnoihiza (Linn.) }\end{array}$} & \multirow{2}{*}{ South China Sea } & \multirow{2}{*}{$\begin{array}{l}\text { Botryosphaerin F (105) and } \\
\text { LL-Z1271ß (106) }\end{array}$} & MCF-7 and HL-60 & 4.49 and $3.43 \mu \mathrm{M}$ & \multirow{2}{*}{ [58] } \\
\hline & & & & & HL-60 & $0.6 \mu \mathrm{M}$ & \\
\hline 38 & Penicillium sp. J-54 & Leaves, Ceriops tagal & $\begin{array}{l}\text { Hainan province, } \\
\text { China }\end{array}$ & Penicieudesmol B (107), & K-562 & $\begin{array}{c}90.1 \mu \mathrm{M}, \\
\text { (paclitaxel, } 9.5 \mu \mathrm{M} \text { ) }\end{array}$ & [59] \\
\hline 39 & $\begin{array}{c}\text { Penicillium citrinum } \\
\text { HL-5126 }\end{array}$ & $\begin{array}{l}\text { Bruguiera sexangula var. } \\
\text { rhynchopetala }\end{array}$ & South China Sea & Penibenzophenone B (108) & A549 Cells & $15.7 \mu \mathrm{g} / \mathrm{mL}$ & [60] \\
\hline 40 & Penicillium sp. & Panax notoginseng & $\begin{array}{l}\text { Wenshan, Yunnan } \\
\text { province, China }\end{array}$ & $\begin{array}{c}\text { Brefeldin A (109), Brefeldin A } \\
\text { 7-O-acetate (110) }\end{array}$ & $\begin{array}{l}\text { 293, HepG2, Huh7 and } \\
\text { KB cell line }\end{array}$ & $\begin{array}{l}\mathrm{LD}_{50} \text { value from } 0.024 \\
\text { to } 0.62 \mu \mathrm{M} \text {. Both the } \\
\text { compounds arrested } \\
\text { HepG2 cells at the } \\
\mathrm{S} \text { phase }\end{array}$ & [61] \\
\hline 41 & $\begin{array}{c}\text { Penicillium } \\
\text { chrysogenum V11 }\end{array}$ & $\begin{array}{l}\text { Vein of Myoporum } \\
\text { bontioides }\end{array}$ & $\begin{array}{l}\text { Leizhou Peninsula, } \\
\text { China }\end{array}$ & Penochalasin K (111) & $\begin{array}{l}\text { MDA-MB-435, SGC-7901 and } \\
\text { A549 cells }\end{array}$ & $<10 \mu \mathrm{M}$ & [62] \\
\hline 42 & $\begin{array}{l}\text { Penicillium } \\
\text { janthinellum } \\
\text { HDN13-309 }\end{array}$ & Sonneratia caseolaris & $\begin{array}{l}\text { Hainan Province, } \\
\text { China }\end{array}$ & $\begin{array}{l}\text { Penicisulfuranols A-C } \\
\quad(\mathbf{1 1 2}-\mathbf{1 1 4})\end{array}$ & HeLa and HL-60 Cells & $\begin{array}{l}\text { In the range of } 0.1 \text { to } \\
\qquad 3.9 \mu \mathrm{M}\end{array}$ & [63] \\
\hline \multirow[t]{2}{*}{43} & \multirow[t]{2}{*}{$\begin{array}{l}\text { Penicillium } \\
\text { chrysogenum V11 }\end{array}$} & \multirow[t]{2}{*}{ Not reported } & \multirow[t]{2}{*}{ Not reported } & $\begin{array}{c}\text { Penochalasin I (115), } \\
\text { chaetoglobosins A (116), and } \\
\text { cytoglobosin C (117) }\end{array}$ & $\begin{array}{l}\text { MDA-MB-435 and } \\
\text { SGC-7901 cells }\end{array}$ & $<10 \mu \mathrm{M}$ & \multirow[t]{2}{*}{ [64] } \\
\hline & & & & Compounds (116), and (117) & SGC-7901 and A549 cells & $<10 \mu \mathrm{M}$ & \\
\hline \multirow[b]{2}{*}{44} & \multirow[b]{2}{*}{$\begin{array}{l}\text { Penicillium brocae } \\
\text { MA-231 }\end{array}$} & \multirow[b]{2}{*}{$\begin{array}{l}\text { Mangrove plant } \\
\text { Avicennia marina }\end{array}$} & \multirow[b]{2}{*}{ Hainan Island, China } & Spirobrocazine C (118) & A2780 & $59 \mu \mathrm{M}$ & \multirow[b]{2}{*}{ [65] } \\
\hline & & & & Brocazine G (119) & A2780 and A2780 CisR & $\begin{array}{c}664 \mathrm{nM}, 661 \mathrm{nM} \\
\text { (cisplatin } 1.67 \text { and } \\
12.63 \mu \mathrm{M} \text { ) }\end{array}$ & \\
\hline
\end{tabular}


Table 1. Cont

\begin{tabular}{|c|c|c|c|c|c|c|c|}
\hline $\begin{array}{l}\text { Sr. } \\
\text { No. }\end{array}$ & Fungus & Host Plant(s) & $\begin{array}{l}\text { Plant Part or Tissue } \\
\text { Locality of } \\
\text { Host Plants }\end{array}$ & Compounds Isolated & Cell Line & $\mathrm{IC}_{50 /} \mathrm{EC}_{50} /$ Inhibition & Refs. \\
\hline \multicolumn{8}{|c|}{ Compounds Produced by Ascomycetes } \\
\hline \multirow[t]{3}{*}{45} & \multirow{3}{*}{$\begin{array}{l}\text { Penicillium brocae } \\
\text { MA- } 231\end{array}$} & \multirow{3}{*}{$\begin{array}{l}\text { Mangrove plant } \\
\text { Avicennia marina }\end{array}$} & \multirow[t]{3}{*}{ Hainan Island, China } & $\begin{array}{c}\text { Brocazines A (120), B (121), } \\
\text { E (122), F (123) }\end{array}$ & $\begin{array}{l}\text { Du145, Hela, HepG2, MCF-7, } \\
\text { NCI-H460, SGC-7901, SW1990, } \\
\text { SW480, and U251 }\end{array}$ & from 0.89 to $9.0 \mu \mathrm{M}$ & \multirow[t]{3}{*}{ [66] } \\
\hline & & & & Compounds (120) and (121) & SW480 tumor cell line & 2.0 and $1.2 \mu \mathrm{M}$ & \\
\hline & & & & Compound (123) & DU145 and NCI-H460 Cells, & 1.7 and $0.89 \mu \mathrm{M}$ & \\
\hline \multirow{7}{*}{46} & \multirow{7}{*}{$\begin{array}{c}\text { Penicillium } \\
\text { chermesinum strain } \\
\text { HLit-ROR2 }\end{array}$} & \multirow{7}{*}{ Heritiera littoralis, } & \multirow{7}{*}{$\begin{array}{l}\text { Samut Sakhon } \\
\text { province, Thailand }\end{array}$} & TMC-264 (124) & T47D and MDA-MB231 & $\begin{array}{c}1.08 \text { and } 2.81 \mu \mathrm{M} \\
\text { (doxorubicin } 1.55 \text { and } \\
2.24 \mu \mathrm{M} \text { ) }\end{array}$ & \multirow{7}{*}{ [67] } \\
\hline & & & & & HepG2 & $\begin{array}{l}3.27 \mu \mathrm{M} \text { (Etoposide, } \\
35.66 \mu \mathrm{M})\end{array}$ & \\
\hline & & & & & MOLT-3 & $1.36 \mu \mathrm{M}$ & \\
\hline & & & & & T47D & $1.08 \mu \mathrm{M}$ & \\
\hline & & & & PR-toxin (125) & $\begin{array}{c}\text { HuCCA-1, HeLa, T47D, and } \\
\text { MDA-MB231 }\end{array}$ & $\begin{array}{l}0.81-2.19 \mu \mathrm{M} \\
\text { (doxorubicin, } \\
0.26-2.24 \mu \mathrm{M} \text { ) }\end{array}$ & \\
\hline & & & & & HL-60 cell line & $\begin{array}{c}0.06 \mu \mathrm{M} \text { (doxorubicin, } \\
1.21 \mu \mathrm{M})\end{array}$ & \\
\hline & & & & & MOLT-3 and HL-60 & $0.09 \mu \mathrm{M}, 0.06 \mu \mathrm{M}$ & \\
\hline \multirow{3}{*}{47} & \multirow{3}{*}{$\begin{array}{l}\text { Penicillium } \\
\text { chrysogenum } \\
\text { HND11-24 }\end{array}$} & \multirow{3}{*}{$\begin{array}{l}\text { The rhizosphere soil of } \\
\text { the mangrove plant } \\
\text { Acanthus ilicifolius }\end{array}$} & \multirow{3}{*}{ China } & Penicitols A (126) & \multirow{3}{*}{$\begin{array}{l}\text { HeLa, BEL-7402, HEK-293, } \\
\text { HCT-116, and A549 Cells }\end{array}$} & $4.6-10.5 \mu \mathrm{M}$ & \multirow{3}{*}{ [68] } \\
\hline & & & & Penicitols B (127) & & $3.4-9.6 \mu \mathrm{M}$ & \\
\hline & & & & $\begin{array}{c}\text { Penicitols C (128) and } \\
\text { Penixanacid A (129) }\end{array}$ & & $\begin{array}{l}\text { In the range of } \\
10-40.5 \mu \mathrm{M}\end{array}$ & \\
\hline \multirow{3}{*}{48} & \multirow{3}{*}{ Penicillium sp. FJ-1 } & \multirow{3}{*}{ Avicennia marina } & \multirow{3}{*}{ Fujian, China } & Compound (130) & Tca8113 and MG-63 cells & $\begin{array}{c}26 \text { and } 35 \mu \mathrm{M} \\
\text { (Taxol, } 46 \text { and } 10 \mathrm{nM})\end{array}$ & \multirow{3}{*}{ [69] } \\
\hline & & & & Compounds (131) & Tca8113 and WRL-68 & 10 and $58 \mu \mathrm{M}$ & \\
\hline & & & & Compounds (131) & MG-63 cells & $55 \mathrm{nM}$ & \\
\hline
\end{tabular}


Table 1. Cont

\begin{tabular}{|c|c|c|c|c|c|c|c|}
\hline $\begin{array}{l}\text { Sr. } \\
\text { No. }\end{array}$ & Fungus & Host Plant(s) & $\begin{array}{l}\text { Plant Part or Tissue } \\
\text { Locality of } \\
\text { Host Plants }\end{array}$ & Compounds Isolated & Cell Line & $\mathrm{IC}_{50 /} \mathrm{EC}_{50} /$ Inhibition & Refs. \\
\hline \multicolumn{8}{|c|}{ Compounds Produced by Ascomycetes } \\
\hline 49 & Penicillium sp. GD6, & Bruguiera gymnorrhiza & Zhanjiang, China & Meleagrin (132) & HL60 and A549 & 9.7 and $8.3 \mu \mathrm{M}$ & [70] \\
\hline \multirow[t]{3}{*}{50} & \multirow[t]{3}{*}{ Penicillium 303\# } & \multirow[t]{3}{*}{ Sea water } & \multirow{3}{*}{$\begin{array}{c}\text { Guangdong Province, } \\
\text { China }\end{array}$} & $\begin{array}{c}\text { 5S, 7R, 9S, 10S, 11R, 12S, 13R, } \\
\text { 22R, and 23R. (133), 7R, 9S, } \\
\text { 10S, 11R, 12S, 13R, 22R, and } \\
\text { 23R (134) }\end{array}$ & $\begin{array}{l}\text { MDA-MB-435, HepG2, } \\
\text { HCT-116, and A549 }\end{array}$ & $\begin{array}{l}\text { In the range of } \\
11.9-37.82 \mu \mathrm{g} / \mathrm{mL}\end{array}$ & \multirow[t]{3}{*}{ [71] } \\
\hline & & & & Compounds (135) & MDA-MB-435 & 7.13 & \\
\hline & & & & Compound (136) & HepG2 and HCT-116 & 39.64 and $27.80 \mu \mathrm{M}$ & \\
\hline 51 & Penicillium sp. ZH58 & Leaves, Avicennia sp. & $\begin{array}{l}\text { Dong Sai, Hainan of } \\
\text { the South China } \\
\text { Sea coast }\end{array}$ & $\begin{array}{l}\text { 4-(methoxymethyl)-7-methoxy- } \\
\text { 6-methyl-1(3H)- } \\
\text { isobenzofuranone (137) }\end{array}$ & $\mathrm{KB}$ and $\mathrm{KB}_{\mathrm{V}} 200$ cells & 6 and $10 \mu \mathrm{g} / \mathrm{mL}$ & [72] \\
\hline 52 & $\begin{array}{l}\text { Penicillium sumatrense } \\
\text { MA-92 }\end{array}$ & $\begin{array}{l}\text { Rhizosphere, Lumnitzera } \\
\text { racemose }\end{array}$ & $\begin{array}{l}\text { WenChang in Hainan } \\
\text { Island, China }\end{array}$ & $\begin{array}{c}\text { Sumalarins A-C (138, 139, } \\
\text { 140), and dehydrocurvularin } \\
\text { (141) }\end{array}$ & $\begin{array}{l}\text { Du145, HeLa, Huh 7, MCF-7, } \\
\text { NCI-H460, SGC-7901, and } \\
\text { SW1990 Cells }\end{array}$ & $\begin{array}{l}\text { In the range of } 3.8 \text { to } \\
\qquad 10 \mu \mathrm{M}\end{array}$ & [73] \\
\hline 53 & Penicillium sp. ZH16 & Avicennia sp. & South China Sea & $\begin{array}{l}\text { 5-methyl-8-(3-methylbut-2-enyl) } \\
\quad \text { furanocoumarin (142) }\end{array}$ & $\mathrm{KB}$ and $\mathrm{KB}_{\mathrm{V}} 200$ & 5 and $10 \mu \mathrm{g} / \mathrm{mL}$ & [74] \\
\hline \multirow{3}{*}{54} & Trichoderma sp. 307 & \multirow{3}{*}{$\begin{array}{c}\text { Stem bark, Clerodendrum } \\
\text { inerme }\end{array}$} & \multirow{3}{*}{$\begin{array}{l}\text { Guangdong Province, } \\
\text { China }\end{array}$} & $\begin{array}{l}\text { (3S)-6-oxo-de-O-methyllasiodiple } \\
\text { (143) }\end{array}$ & \multirow{3}{*}{ GH3 and MMQ Cells RPC } & $\begin{array}{c}21.42 \text { and } 13.59 \mu \mathrm{M}, \\
142.8 \mu \mathrm{M}\end{array}$ & \multirow{3}{*}{ [75] } \\
\hline & \multirow{2}{*}{$\begin{array}{c}\text { Co cultured with } \\
\text { Acinetobacter johnsonii } \\
\text { B2 }\end{array}$} & & & $\begin{array}{c}\text { (3R)-de-O-methyllasiodiplodin } \\
(\mathbf{1 4 4})\end{array}$ & & $\begin{array}{c}6.44 \text { and } 6.58 \mu \mathrm{M}, 6.94 \\
\mu \mathrm{M}\end{array}$ & \\
\hline & & & & (3R)-nordinone (145) & & $\begin{array}{l}12.33 \text { and } 10.13 \mu \mathrm{M}, \\
100.03 \mu \mathrm{M} \text {. }\end{array}$ & \\
\hline 55 & $\begin{array}{c}\text { Trichoderma sp. } 307 \\
\text { co-culturing with } \\
\text { Acinetobacter johnsonii } \\
\text { B2 }\end{array}$ & $\begin{array}{l}\text { Stem bark of } \\
\text { Clerodendrum inerme }\end{array}$ & $\begin{array}{c}\text { Guangdong Province, } \\
\text { China }\end{array}$ & Botryorhodine H (146) & MMQ GH3 Cells & 3.09 and $3.64 \mu \mathrm{M}$ & [76] \\
\hline 56 & Trichoderma sp. Хy24 & $\begin{array}{l}\text { Leaves, stems and peels } \\
\text { of Xylocarpus granatum }\end{array}$ & $\begin{array}{l}\text { Hainan province, } \\
\text { China }\end{array}$ & $\begin{array}{c}(9 R, 10 R) \text {-dihydro-harzianone } \\
\text { (147) }\end{array}$ & HeLa and MCF-7 Cells & $30.1 \mu \mathrm{M}$ and $30.7 \mu \mathrm{M}$ & [77] \\
\hline
\end{tabular}


Table 1. Cont

\begin{tabular}{|c|c|c|c|c|c|c|c|}
\hline $\begin{array}{l}\text { Sr. } \\
\text { No. }\end{array}$ & Fungus & Host Plant(s) & $\begin{array}{c}\text { Plant Part or Tissue } \\
\text { Locality of } \\
\text { Host Plants }\end{array}$ & Compounds Isolated & Cell Line & $\mathrm{IC}_{50 /} \mathrm{EC}_{50} /$ Inhibition & Refs. \\
\hline \multicolumn{8}{|c|}{ Compounds Produced by Ascomycetes } \\
\hline 57 & Nigrospora sp. MA75 & Pongamia pinnata & $\begin{array}{c}\text { Guangxi Zhuang } \\
\text { Autonomous Region } \\
\text { of China }\end{array}$ & $\begin{array}{l}\text { 2,3-didehydro-19 } \alpha \text {-hydroxy- } \\
\text { 14-epicochlioquinone B (148) }\end{array}$ & $\begin{array}{l}\text { MCF-7, SW1990, and } \\
\text { SMMC7721 }\end{array}$ & 4,5, and $7 \mu \mathrm{g} / \mathrm{mL}$ & [78] \\
\hline 58 & $\begin{array}{l}\text { Fusarium sp. } \\
\text { (No. DZ27) }\end{array}$ & Bark of Kandelia candel & $\begin{array}{l}\text { Dongzhai mangrove, } \\
\text { Hainan, China }\end{array}$ & Beauvericin (104) & $\mathrm{KB}$ and $\mathrm{KBv} 200$ cells & 5.76 and $5.34 \mu \mathrm{M}$ & [79] \\
\hline 59 & Fusarium sp. & $\begin{array}{l}\text { Leaf of mangrove } \\
\text { Kandelia candel }\end{array}$ & $\begin{array}{l}\text { Dongzhai Harbor of } \\
\text { Hainan Island, China }\end{array}$ & Apicidin (149) & GLC-82 cells & $6.94 \mu \mathrm{M}$ & [80] \\
\hline 60 & $\begin{array}{l}\text { Unidentified fungus } \\
\text { ZZF42 }\end{array}$ & South China Sea & Not reported & Apicidin (149) & $\mathrm{KB}$ and $\mathrm{KBv} 200$ & $0.78 \mu \mathrm{g} / \mathrm{mL}$ & [81] \\
\hline \multirow{6}{*}{61} & \multirow{2}{*}{$\begin{array}{l}\text { Fusarium incarnatum } \\
\text { (HKI0504) }\end{array}$} & \multirow{2}{*}{ Aegiceras corniculatum } & \multirow{2}{*}{ Not reported } & \multirow{2}{*}{$\begin{array}{c}\text { 2-acetyl-1,2,3,4-tetrahydro- } \\
\beta \text {-carboline (150) }\end{array}$} & HUVEC and K-562 & $\mathrm{GI}_{50} 41.1$ and 33.3 & \multirow{2}{*}{ [82] } \\
\hline & & & & & HeLa cell & $\mathrm{CC}_{50} 23.8 \mu \mathrm{M}$ & \\
\hline & \multirow{2}{*}{$\begin{array}{l}\text { Fusarium incarnatum } \\
\text { (HKI0504) }\end{array}$} & \multirow{2}{*}{ Aegiceras corniculatum } & \multirow{2}{*}{ Not reported } & \multirow{2}{*}{ Fusamine (151) } & HUVEC and K-562 & $\mathrm{GI}_{50} 37.3$ and 37.6 & \multirow{2}{*}{ [82] } \\
\hline & & & & & HeLa cell & $\mathrm{CC}_{50} 23.3 \mu \mathrm{M}$ & \\
\hline & \multirow{2}{*}{$\begin{array}{l}\text { Fusarium incarnatum } \\
\text { (HKI0504) }\end{array}$} & \multirow{2}{*}{ Aegiceras corniculatum } & \multirow{2}{*}{ Not reported } & \multirow{2}{*}{$\begin{array}{l}\text { 3-(1-aminoethylidene)-6- } \\
\text { methyl-2H-pyran-2,4(3H)- } \\
\text { dione (152) }\end{array}$} & HUVEC and K-562 & $\mathrm{GI}_{50} 41.1$ and 33.3 & \multirow{2}{*}{ [82] } \\
\hline & & & & & HeLa cell & $\mathrm{CC}_{50} 23.8 \mu \mathrm{M}$ & \\
\hline \multirow{2}{*}{62} & \multirow{2}{*}{ Acremonium sp. } & \multirow{2}{*}{$\begin{array}{l}\text { leaves of Sonneratia } \\
\text { caseolaris c }\end{array}$} & \multirow{2}{*}{$\begin{array}{l}\text { Dong Zhai Gang } \\
\text { Mangrove Garden, } \\
\text { Hainan, China }\end{array}$} & \multirow{2}{*}{ Torrubiellin B (153) } & $\begin{array}{c}\text { Cisplatin sensitive Cal27, } \\
\text { Kyse510, HCC38, A2780, } \\
\text { MDA-MB-231 }\end{array}$ & $\begin{array}{l}\text { In the range of } 0.3 \text { to } \\
\qquad 1.5 \mu \mathrm{M}\end{array}$ & \multirow{2}{*}{ [83] } \\
\hline & & & & & $\begin{array}{c}\text { Cisplatin resistant, Cal27, } \\
\text { Kyse510, HCC38, A2780, } \\
\text { MDA-MB-231 }\end{array}$ & $\begin{array}{l}\text { In the range of } 0.2 \text { to } \\
\qquad 2.6 \mu \mathrm{M}\end{array}$ & \\
\hline \multirow{2}{*}{63} & \multirow{2}{*}{ Acremonium strictum } & \multirow{2}{*}{ Rhizophora apiculata } & \multirow{2}{*}{$\begin{array}{l}\text { Island of Cat Ba, } \\
\text { Vietnam }\end{array}$} & \multirow{2}{*}{$\begin{array}{l}\text { Waol A (154), Pestalotiopene } \\
\text { A (155) Cytosporone E (156) }\end{array}$} & Cisplatin-sensitive, A2780 & $27.1,76.2$, and $8.3 \mu \mathrm{M}$ & \multirow{2}{*}{ [84] } \\
\hline & & & & & Cisplatin-Resistant A2780 & 12.6, 30.1, and $19.0 \mu \mathrm{M}$ & \\
\hline 64 & Endophytic fungus J3 & Ceriops tagal & $\begin{array}{l}\text { Hainan province, } \\
\text { China }\end{array}$ & 3,4-seco-sonderianol (157) & $\begin{array}{l}\text { K562, SGC-7901, and } \\
\text { BEL-7402 Cells }\end{array}$ & $\begin{array}{l}9.2,15.7, \text { and } \\
25.4 \mu \mathrm{g} / \mathrm{mL}\end{array}$ & [85] \\
\hline 65 & $\begin{array}{l}\text { Endophytic fungus } \\
\text { No. ZH-3 }\end{array}$ & Not reported & South China Sea & $\begin{array}{c}\text { 2-(3-chloro-2, } \\
\text { 6-dihydroxy-4-methylbenzoyl)- } \\
\text { 5-hydroxy-3-methoxybenzoate } \\
\text { (158) }\end{array}$ & HepG2 cell line & $25 \mu \mathrm{g} / \mathrm{mL}$ & [86] \\
\hline
\end{tabular}


Table 1. Cont

\begin{tabular}{|c|c|c|c|c|c|c|c|}
\hline $\begin{array}{l}\text { Sr. } \\
\text { No. }\end{array}$ & Fungus & Host Plant(s) & $\begin{array}{l}\text { Plant Part or Tissue } \\
\text { Locality of } \\
\text { Host Plants }\end{array}$ & Compounds Isolated & Cell Line & $\mathrm{IC}_{50 /} \mathrm{EC}_{50} /$ Inhibition & Refs. \\
\hline \multicolumn{8}{|c|}{ Compounds Produced by Ascomycetes } \\
\hline 66 & $\begin{array}{l}\text { Endophytic fungus } \\
\text { No. } 5094\end{array}$ & Not reported & South China Sea & Anthracene derivative (159) & KB and KBv200 & $\begin{array}{c}\mathrm{LD}_{50} \text { values of } 5.5 \text { and } \\
10.2 \mu \mathrm{M}\end{array}$ & [87] \\
\hline \multirow{2}{*}{67} & \multirow{2}{*}{$\begin{array}{l}\text { Co-cultures of two } \\
\text { mangrove endophytic } \\
\text { fungi (strains Nos. } \\
1924 \text { and 3893) }\end{array}$} & \multirow{2}{*}{ Not reported } & & Marinamide (160) & $\begin{array}{c}\text { HepG2, 95-D, MGC832 and } \\
\text { HeLa Cells }\end{array}$ & $\begin{array}{c}\text { 7.0, } 0.4,91 \mathrm{nM} \text { and } \\
0.529 \mu \mathrm{M}\end{array}$ & \multirow{2}{*}{ [88] } \\
\hline & & & & Methyl marinamide (161) & $\begin{array}{c}\text { HepG2, 95-D, MGC832 and } \\
\text { HeLa Cells }\end{array}$ & $2.52,1.5413,0.110 \mu \mathrm{M}$ & \\
\hline 68 & $\begin{array}{l}\text { Endophytic fungus } \\
\text { No.Gx-3a }\end{array}$ & Not reported & South China sea & Ditryptophenaline (162) & KB, KBv200 & 8.0 and $12.0 \mu \mathrm{M}$ & [89] \\
\hline 69 & $\begin{array}{l}\text { Mangrove endophytic } \\
\text { fungus No.SK7RN3G1 }\end{array}$ & Not reported & South China Sea & $\begin{array}{l}\text { 3,8-dihydroxy-6-methyl-9- } \\
\text { oxo-9H-xanthene-1-carboxylate } \\
\text { (163), Lichenxanthone (164), }\end{array}$ & HepG2 cell line & 20 and $25 \mu \mathrm{g} / \mathrm{mL}$ & [90] \\
\hline \multicolumn{8}{|c|}{ Compounds Produced by Basidiomycetes } \\
\hline 70 & $\begin{array}{l}\text { Basidiomycetous } \\
\text { fungus XG8D }\end{array}$ & $\begin{array}{l}\text { leaves of Xylocarpus } \\
\text { granatum }\end{array}$ & $\begin{array}{c}\text { Samutsakorn } \\
\text { province, Thailand }\end{array}$ & Merulinols C and D $(\mathbf{1 6 5}, \mathbf{1 6 6})$ & KATO-3 cells & 35.0 and $25.3 \mu \mathrm{M}$ & [91] \\
\hline \multirow{7}{*}{71} & \multirow{7}{*}{$\begin{array}{c}\text { Pseudolagarobasidium } \\
\text { acaciicola }\end{array}$} & \multirow{7}{*}{ Bruguiera gymnorrhiza } & \multirow{7}{*}{$\begin{array}{l}\text { Samut Sakhon } \\
\text { province, Thailand }\end{array}$} & \multirow{3}{*}{ Compound (167) } & $\begin{array}{l}\text { HuCCA-1, A549, MOLT-3, } \\
\text { HepG2, MDA-MB231, T47D }\end{array}$ & $0.28-37.46 \mu \mathrm{M}$ & \multirow{7}{*}{ [92] } \\
\hline & & & & & MRC-5 & $\mathrm{IC}_{50} 17.92 \mu \mathrm{M}$ & \\
\hline & & & & & HL-60 cell line & $\mathrm{IC}_{50} 0.28 \mu \mathrm{M}$ & \\
\hline & & & & Compound (168) & $\begin{array}{l}\text { A549, MOLT-3, HepG2, HL-60, } \\
\text { MDA-MB231, T47D, HeLa } \\
\text { cancer cell, MRC-5 }\end{array}$ & $12.09-170.08 \mu \mathrm{M}$ & \\
\hline & & & & Compound (169) & $\begin{array}{c}\text { HuCCA-1, A549, MOLT-3, } \\
\text { HepG2, HL-60, MDA-MB231, } \\
\text { T47D, HeLa cancer cell }\end{array}$ & $15.20-76.97 \mu \mathrm{M}$ & \\
\hline & & & & \multirow[t]{2}{*}{ Compound (170) } & $\begin{array}{c}\text { HuCCA-1, A549, MOLT-3, } \\
\text { HepG2, MDA-MB231, T47D, } \\
\text { HeLa cancer cell }\end{array}$ & $18.31-154.51 \mu \mathrm{M}$ & \\
\hline & & & & & HL-60 & $18.31 \mu \mathrm{M}$ & \\
\hline
\end{tabular}


Table 1. Cont

\begin{tabular}{|c|c|c|c|c|c|c|c|}
\hline $\begin{array}{l}\text { Sr. } \\
\text { No. }\end{array}$ & Fungus & Host Plant(s) & $\begin{array}{l}\text { Plant Part or Tissue } \\
\text { Locality of } \\
\text { Host Plants }\end{array}$ & Compounds Isolated & Cell Line & $\mathrm{IC}_{50 /} \mathrm{EC}_{50} /$ Inhibition & Refs. \\
\hline \multicolumn{8}{|c|}{ Compounds Produced by Basidiomycetes } \\
\hline \multirow{4}{*}{72} & \multirow{4}{*}{$\begin{array}{c}\text { Pseudolagarobasidium } \\
\text { acaciicola }\end{array}$} & \multirow{4}{*}{ Bruguiera gymnorrhiza } & \multirow{4}{*}{ Not reported } & $\begin{array}{l}\text { Endoperoxide (171), } \\
\text { Steperoxide A (172) }\end{array}$ & $\begin{array}{l}\text { MOLT-3, HuCCA-1, A549, } \\
\text { HepG2, HL-60, MDA-MB-231, } \\
\text { T47D, and HeLa cancer Cells }\end{array}$ & $\begin{array}{l}\text { In the range of } 0.68-3.71 \\
\text { and } 0.67-5.25 \mu \mathrm{g} / \mathrm{mL}\end{array}$ & \multirow{4}{*}{ [93] } \\
\hline & & & & Merulin B (173) & $\begin{array}{l}\text { MOLT-3, A549, HepG2, HL-60, } \\
\text { MDA-MB-231 and T47D Cells }\end{array}$ & $\begin{array}{c}\text { In the range of } \\
11.94-49.08 \mu \mathrm{g} / \mathrm{mL}\end{array}$ & \\
\hline & & & & Merulin C (174) & HL60 cancer cells & $0.08 \mu \mathrm{g} / \mathrm{mL}$ & \\
\hline & & & & & $\begin{array}{l}\text { MOLT-3, HuCCA-1, A549, } \\
\text { HepG2, MDA-MB-231, T47D, } \\
\text { and HeLa Cells }\end{array}$ & $\begin{array}{l}\text { In the range of } \\
0.19-3.75 \mu \mathrm{g} / \mathrm{mL}\end{array}$ & \\
\hline \multirow{2}{*}{73} & \multirow{2}{*}{$\begin{array}{l}\text { Mucor irregularis } \\
\text { QEN-189 }\end{array}$} & \multirow{2}{*}{ Rhizophora stylosa } & \multirow{2}{*}{ Hainan Island, China } & 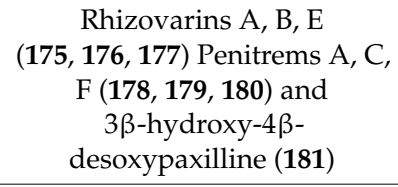 & A-549 & $\begin{array}{c}11.5,6.3,9.2,8.4,8.0,8.2 \\
\text { and } 4.6 \mu \mathrm{M}\end{array}$ & \multirow{2}{*}{ [94] } \\
\hline & & & & 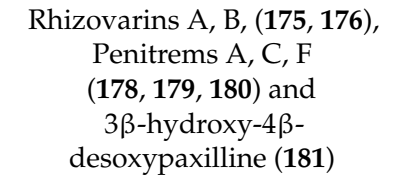 & HL-60 & $\begin{array}{c}9.6,5.0,7.0,4.7,3.3 \text { and } \\
2.6 \mu \mathrm{M}\end{array}$ & \\
\hline
\end{tabular}




\section{Methods Used for the Activation of Silent Biosynthetic Genes}

Recent studies in the marine-based microorganisms have shown that these microorganisms are a rich source for novel bioactive compounds. Salinosporamide A (marizomib), a microbial compound isolated from marine Salinispora bacteria with proteasome inhibitory activity is expected to be a future anti-cancer drug, and is presently under clinical trials [95]. However, the reoccurrence of the same compound as discovered in terrestrial sources, in marine microorganisms often leads to serious issues. Advances in molecular biology have enhanced our understanding regarding how to exploit the genetic potential of bacteria and fungi to produce newer chemical entities apart from those that are currently known, which have yet to be explored [96,97]. It has been reported that under laboratory conditions, biosynthetic genes are not expressed as such, as only limited bioactive compounds are produced by these microbes. To overcome these limitations, different strategies have been proposed, including culturing promising strains in varying culture media and under a variety of culture conditions [98], mixing cultures of two or more microbe variants and epigenetic modifications that treat microbes with epigenetic modifiers such as histone deacetylase inhibitors or DNA methyl transferase to initiate the transcription of silent genes $[99,100]$ to enhance the variation and diversity of the produced metabolites.

\subsection{The Co-Culture Strategy}

Microbes in natural ecosystem conditions always harbor and flourish in co-existence with a variety of microbes. Antagonism and competition for limited resources often lead to high competition among species, and microbes adopt various defense strategies, which favor the production of important bioactive secondary metabolites [101]. The co-culturing of two or more different microbes at the laboratory scale might mimic the ecological setting and induce the cascade of genes responsible for biosynthesis that are normally are masked under optimum culture parameters. Co-cultivation of two Aspergillus species derived from mangroves produced the new alkaloid aspergicin and the previously recognized compounds neoaspergillic acid and ergosterol, with antibacterial activity [102]. Li et al. [103] co-cultured two mangrove epiphytes and identified a novel xanthone derivative compound that showed antifungal activity. Two new alkaloids, marinamide, and marinamide methylether, were reported from mangrove-derived endophytic fungi with a cytotoxic effect when grown in mixed fermentation [88]. Pestalone, a chlorinated prenylsecoanthraquinone, was produced by the marine-derived fungus Pestalotia sp. when grown in the presence of the marine-derived bacterium Thalassopia sp., which belongs to the Gram-negative group. [104]. When Libertella sp., a marine-based fungi, were cultured in the presence of the bacteria Thalassopia sp., it resulted in the production of diterpenoid libertellenones of fungal origin [105]. In another set of studies, when the bacterium Sphingomonas sp. was grown in the presence of Aspergillus fumigatus, a novel compound glionitrin A, a diketopiperazine disulfide, was identified and appeared to show strong cytotoxicity against HCT-116, A549, AGS and DU145 cells [106]. These studies suggest that co-cultivation has tremendous potential to generate novel chemical entities from microbes when cultured under laboratory conditions.

\subsection{Epigenetic Modification}

The addition of epigenetic modifiers to fungi would allow us to induce cryptic fungal gene clusters. This technique can be applied to any fungal strain and does not require strain-dependent genetic manipulation. Williams et al. [107] reported that epigenetic modifiers could be rationally employed to access silent natural product pathways. Histone deacetylase (HDAC) or DNA methyltransferase (DMAT) are often used as epigenetic agents to change the transcription rate of some genes [108]. Henrikson et al. [12] reported the identification of nygerone A from A. niger when grown with suberoylanilide hydoxamic acid (SAHA). Wang et al. [109] reported induced metabolite generation in Penicillium citreonigrum when grown in the presence of methyl transferase inhibitor, 5-azacytidine (5-AZA). When Hypoxylon sp., an endophytic fungi, was treated with the epigenetic modifiers SAHA and AZA it enhanced the production of volatile organic compounds (VOCs) [110]. 
The marine endophytic fungus Leucostoma persoonii from Rhizophora mangle enhanced the production of cytosporones B, C, E and R in HDAC inhibited fermentation [111]. These studies provide evidence that the use of epigenetic modifiers modulate secondary metabolite production, resulting in different gene expressions.

\section{Conclusions}

Mangrove fungi are a ubiquitous source of novel bioactive metabolites with the potential to display anticancer properties. It is interesting to observe the chemical diversity in these metabolites, which include simple glycoside (27) and peptide molecules (pullularins E, 89; F, 90 and apicidin, 149) as well as complex stereospecific structures such as cytochalasin H (18), phomopsichalasin G (19), aniquinazolines A-D (98-101) and penitrem A, B and F (178-180). Chemical diversity plays an important role in the drug discovery pipeline, as this provides structurally diverse scaffolds that display similar activity via different modes and/or mechanisms of action. This phenomenon is also observed in mangrove fungal metabolites, as they show potent anticancer activity via different mechanisms of action such as apoptotic cell death (SZ-685C, 73; beauvericin, 104), the inhibition of kinase proteins involved in signal transduction pathways (Mycoepoxydiene, 32; Altersolanol A, 64; and the inhibition of topoisomerase I (36). Although many metabolites demonstrated moderate cytotoxic activities against cancer cell lines, only a few displayed superior activity than the standard anticancer drugs (98-101, $119,124)$. It can be suggested that the rational derivatization of metabolites may provide molecules with better activity against a wide range of cancer cell lines. In addition, the identified metabolites with broad-spectrum anticancer activity need to be investigated to establish their mechanisms of action and to develop as novel anticancer therapeutics.

Author Contributions: The manuscript was critically evaluated by S.K.D., V.P., M.S.R. and M.K.G. The chemical structures were drawn by V.P. and M.K.G. and they assisted in the preparation of Table 1. The manuscript has been read and approved by all named authors.

Funding: This research received no external funding.

Acknowledgments: The authors are thankful to Alok Adholeya, Sustainable Agriculture Division, The Energy and Resources Institute (India) for continuous support.

Conflicts of Interest: The authors declare no conflict of interest.

\section{References}

1. Gopal, B.; Chauhan, M. Biodiversity and its conservation in the Sundarban mangrove ecosystem. Aquat. Sci. 2006, 68, 338-354. [CrossRef]

2. Shearer, C.A.; Descals, E.; Kohlmeyer, B.; Kohlmeyer, J.; Marvanová, L.; Padgett, D.; Porter, D.; Raja, H.A.; Schmit, J.P.; Thorton, H.A.; et al. Fuangal diversity in aquatic habitats. Biodivers. Conserv. 2007, 16, $49-67$. [CrossRef]

3. Sridhar, K.R. Mangrove fungi in India. Curr. Sci. 2004, 86, 1586-1587.

4. Sun, H.H.; Mao, W.J.; Chen, Y.; Guo, S.D.; Li, H.Y.; Qi, X.H.; Chen, Y.L.; Xu, J. Isolation, chemical characteristics and antioxidant properties of the polysaccharides from marine fungus Penicillium sp. F23-2. Carbohydr. Polym. 2009, 78, 117-124. [CrossRef]

5. Balagurunathan, R.; Radhakrishnan, M. Exploiting the less explored-microbial endophytes. Adv. Biotechnol. 2007, 6, 20-23.

6. Kharwar, R.N.; Mishra, A.; Gond, S.K.; Stierle, A.; Stierle, D. Anticancer compounds derived from fungal endophytes: Their importance and future challenges. Nat. Prod. Rep. 2011, 28, 1208-1228. [CrossRef] [PubMed]

7. $\mathrm{Xu}, \mathrm{J}$. Bioactive natural products derived from mangrove associated microbes. RSC Adv. 2015, 5, 841-892. [CrossRef]

8. Stierle, A.; Strobel, G.; Stierle, D. Taxol and taxane production by Taxomyces andreanae, an endophytic fungus of Pacific yew. Science 1993, 260, 214-216. [CrossRef] [PubMed] 
9. Thatoi, H.; Behera, B.C.; Mishra, R.R. Ecological role and biotechnological potential of mangrove fungi: A review. Mycology 2013, 4, 54-71.

10. Marmann, A.; Aly, A.H.; Lin, W.; Wang, B.; Proksch, P. Co-cultivation-A powerful emerging tool for enhancing the chemical diversity of microorganisms. Mar. Drugs 2014, 12, 1043-1065. [CrossRef] [PubMed]

11. Fisch, K.M.; Gillaspy, A.F.; Gipson, M.; Henrikson, J.C.; Hoover, A.R.; Jackson, L.; Najar, F.Z.; Wagele, H.; Cichewicz, R.H. Chemical induction of silent pathway transcription in Aspergillus niger. J. Ind. Microbiol. Biotechnol. 2009, 36, 1199-1213. [CrossRef] [PubMed]

12. Henrikson, J.C.; Hoover, A.R.; Joyner, P.M.; Cichewicz, R.H. A chemical epigenetics approach for engineering the in situ biosynthesis of a cryptic natural product from Aspergillus niger. Org. Biomol. Chem. 2009, 7, 435-438. [CrossRef] [PubMed]

13. Strobel, G.A.; Long, D.M. Endophytic microbes embody pharmaceutical potential. Am. Soc. Microbiol. News 1998, 64, 263-268.

14. Xu, J.; Ebada, S.S.; Proksch, P. Pestalotiopsis a highly creative genus: Chemistry and bioactivity of secondary metabolites. Fungal Divers. 2010, 44, 15-31. [CrossRef]

15. Deshmukh, S.K.; Prakash, V.; Ranjan, N. Recent advances in the discovery of bioactive metabolites from Pestalotiopsis. Phytochem. Rev. 2017, 16, 883-920. [CrossRef]

16. Zhou, J.; Li, G.; Deng, Q.; Zheng, D.; Yang, X.; Xu, J. Cytotoxic constituents from the mangrove endophytic Pestalotiopsis sp. induce G0/G1 cell cycle arrest and apoptosis in human cancer cells. Nat. Prod. Res. 2017, 1-5. [CrossRef] [PubMed]

17. Liu, S.; Dai, H.; Makhloufi, G.; Heering, C.; Janiak, C.; Hartmann, R.; Mándi, A.; Kurtán, T.; Müller, W.E.; Kassack, M.U.; et al. Cytotoxic 14-membered macrolides from a mangrove-derived endophytic fungus Pestalotiopsis microspora. J. Nat. Prod. 2016, 79, 2332-2340. [CrossRef] [PubMed]

18. Hemphill, C.F.P.; Daletos, G.; Liu, Z.; Lin, W.; Proksch, P. Polyketides from the mangrove-derived fungal endophyte Pestalotiopsis clavispora. Tetrahedron Lett. 2016, 57, 2078-2083. [CrossRef]

19. Zhou, X.; Lin, X.; Ma, W.; Fang, W.; Chen, Z.; Yang, B.; Liu, Y. A new aromatic amine from fungus Pestalotiopsis vaccinia. Phytochem. Lett. 2014, 7, 35-37. [CrossRef]

20. Kong, F.; Wang, Y.; Liu, P.; Dong, T.; Zhu, W. Thiodiketopiperazines from the marine-derived fungus Phoma sp. OUCMDZ-1847. J. Nat. Prod. 2014, 77, 132-137. [CrossRef] [PubMed]

21. Ma, Y.; Xiu, Z.; Liu, X.; Huang, B.; Hu, L.; Liu, J.; Zhou, Z.; Tang, X.; Wu, X. Cytochalasin H isolated from mangrove-derived endophytic fungus induces apoptosis and inhibits migration in lung cancer cells. Oncol. Rep. 2018, 39, 2899-2905. [CrossRef] [PubMed]

22. Luo, Y.F.; Zhang, M.; Dai, J.G.; Pedpradab, P.; Wang, W.J.; Wu, J. Cytochalasins from mangrove endophytic fungi Phomopsis sp. xy21 and xy22. Phytochem. Lett. 2016, 17, 162-166. [CrossRef]

23. Song, X.; Zhou, X.; Li, X.; Zheng, C.; Huang, G.; Yu, Z.; Song, X.; Chen, G. Secondary metabolites of a Bruguiera sexangula var. Rhynchopetala-derived fungus Phomopsis longicolla HL-2232. Youji Huaxue 2015, 35, 2102-2107.

24. Ding, B.; Yuan, J.; Huang, X.; Wen, W.; Zhu, X.; Liu, Y.; Li, H.; Lu, Y.; He, L.; Tan, H.; et al. New dimeric members of the phomoxanthone family: Phomolactonexanthones A, B and deacetylphomoxanthone C isolated from the fungus Phomopsis sp. Mar. Drugs 2013, 11, 4961-4972. [CrossRef] [PubMed]

25. Huang, Z.; Yang, J.; Lei, F.; She, Z.; Lin, Y. A new xanthone O-glycoside from the mangrove endophytic fungus Phomopsis sp. Chem. Nat. Compd. 2013, 49, 27-30. [CrossRef]

26. Luo, X.; Lin, X.; Tao, H.; Wang, J.; Li, J.; Yang, B.; Zhou, X.; Liu, Y. Isochromophilones A-F, cytotoxic chloroazaphilones from the marine mangrove endophytic fungus Diaporthe sp. SCSIO 41011. J. Nat. Prod. 2018, 81, 934-941. [CrossRef] [PubMed]

27. Cui, H.; Yu, J.; Chen, S.; Ding, M.; Huang, X.; Yuan, J.; She, Z. Alkaloids from the mangrove endophytic fungus Diaporthe phaseolorum SKS019. Bioorg. Med. Chem. Lett. 2017, 27, 803-807. [CrossRef] [PubMed]

28. Zhang, W.; Zhao, B.; Du, L.; Shen, Y. Cytotoxic polyketides with an oxygen-bridged cyclooctadiene core skeleton from the mangrove endophytic fungus Phomosis sp. A818. Molecules 2017, 22, 1547. [CrossRef] [PubMed]

29. Xia, X.C.; Chen, Q.; Liu, K.; Mo, P.L.; Zhu, J.W.; Zhuang, M.Q.; Shen, Y.M.; Yu, C.D. Mycoepoxydiene inhibits antigen-stimulated activation of mast cells and suppresses IgE-mediated anaphylaxis in mice. Int. Immunopharmacol. 2013, 17, 336-341. [CrossRef] [PubMed] 
30. Li, F.; Guo, W.; Wu, L.; Zhu, T.; Gu, Q.; Li, D.; Che, Q. Saroclazines A-C, thio-diketopiperazines from mangrove-derived fungi Sarocladium kiliense HDN11-84. Arch. Pharm. Res. 2018, 41, 30-34. [CrossRef] [PubMed]

31. Liu, Y.; Stuhldreier, F.; Kurtan, T.; Mandi, A.; Arumugam, S.; Lin, W.; Stork, B.; Wesselborg, S.; Weber, H.; Henrich, B.; et al. Daldinone derivatives from the mangrove-derived endophytic fungus Annulohypoxylon sp. RSC Adv. 2017, 7, 5381-5393. [CrossRef]

32. Zhang, Y.; Jia, A.; Chen, H.; Wang, M.; Ding, G.; Sun, L.; Li, L.; Dai, M. Anthraquinones from the saline-alkali plant endophytic fungus Eurotium rubrum. J. Antibiot. 2017, 70, 1138-1141. [CrossRef] [PubMed]

33. Wang, Y.; Wang, Y.; Wu, A.A.; Zhang, L.; Hu, Z.; Huang, H.; Xu, Q.; Deng, X. New 12,8-Eudesmanolides from Eutypella sp. 1-15. J. Antibiot. 2017, 70, 1029-1032. [CrossRef] [PubMed]

34. Siridechakorn, I.; Yue, Z.; Mittraphab, Y.; Lei, X.; Pudhom, K. Identification of spirobisnaphthalene derivatives with anti-tumor activities from the endophytic fungus Rhytidhysteron rufulum AS21B. Bioorg. Med. Chem. 2017, 25, 2878-2882. [CrossRef] [PubMed]

35. Huang, J.; Xu, J.; Wang, Z.; Khan, D.; Niaz, S.I.; Zhu, Y.; Lin, Y.; Li, J.; Liu, L. New lasiodiplodins from mangrove endophytic fungus Lasiodiplodia sp. 318. Nat. Prod. Res. 2017, 31, 326-332. [CrossRef] [PubMed]

36. Li, J.; Xue, Y.; Yuan, J.; Lu, Y.; Zhu, X.; Lin, Y.; Liu, L. Lasiodiplodins from mangrove endophytic fungus Lasiodiplodia sp. 318\#. Nat. Prod. Res. 2016, 30, 755-760. [PubMed]

37. Chen, S.; Chen, D.; Cai, R.; Cui, H.; Long, Y.; Lu, Y.; Li, C.; She, Z. Cytotoxic and antibacterial preussomerins from the mangrove endophytic fungus Lasiodiplodia theobromae ZJ-HQ1. J. Nat. Prod. 2016, 79, 2397-2402. [CrossRef] [PubMed]

38. Chokpaiboon, S.; Choodej, S.; Boonyuen, N.; Teerawatananond, T.; Pudhom, K. Highly oxygenated chromones from mangrove-derived endophytic fungus Rhytidhysteron rufulum. Phytochemstry 2016, 122, 172-177. [CrossRef] [PubMed]

39. Zhu, M.; Zhang, X.; Feng, H.; Che, Q.; Zhu, T.; Gu, Q.; Li, D. Campyridones A-D, pyridone alkaloids from a mangrove endophytic fungus Campylocarpon sp. HDN13-307. Tetrahedron 2016, 72, 5679-5683. [CrossRef]

40. Moussa, M.; Ebrahim, W.; El-Neketi, M.; Mandi, A.; Kurtan, T.; Hartmann, R.; Lin, W.; Liu, Z.; Proksch, P. Tetrahydroanthraquinone derivatives from the mangrove-derived endophytic fungus Stemphylium globuliferum. Tetrahedron Lett. 2016, 57, 4074-4078. [CrossRef]

41. Liu, Y.; Marmann, A.; Abdel-Aziz, M.S.; Wang, C.Y.; Müller, W.E.G.; Lin, W.H.; Mandi, A.; Kurtan, T.; Daletos, G.; Proksch, P. Tetrahydroanthraquinone derivatives from the endophytic fungus Stemphylium globuliferum. Eur. J. Org. Chem. 2015, 2015, 2646-2653. [CrossRef]

42. Debbab, A.; Aly, A.H.; Edrada-Ebel, R.; Wray, V.; Pretsch, A.; Pescitelli, G.; Kurtan, T.; Proksch, P. New anthracene derivatives-structure elucidation and antimicrobial activity. Eur. J. Org. Chem. 2012, 1351-1359. [CrossRef]

43. Mishra, P.D.; Verekar, S.A.; Deshmukh, S.K.; Joshi, K.S.; Fiebig, H.H.; Kelter, G. Altersolanol A: A selective cytotoxic anthraquinone froma Phomopsis sp. Lett. Appl. Microbiol. 2015, 60, 387-391. [CrossRef] [PubMed]

44. Debbab, A.; Aly, A.H.; Edrada-Ebel, R.; Wray, V.; Muller, W.E.G.; Totzke, F.; Zirrgiebel, U.; Schachtele, C.; Kubbutat, M.H.G.; Lin, W.; et al. Bioactive metabolites from endophytic fungus Stemphylium globuliferum isolated from Mentha pulegium. J. Nat. Prod. 2009, 72, 626-631. [CrossRef] [PubMed]

45. Teiten, M.H.; Mack, F.; Debbab, A.; Aly, A.H.; Dicato, M.; Proksch, P.; Diederich, M. Anticancer effect of altersolanol A, a metabolite produced by the endophytic fungus Stemphylium globuliferum, mediated by its proapoptotic and anti-invasive potential via the inhibition of NF-kB activity. Bioorg. Med. Chem. 2013, 21, 3850-3858. [CrossRef] [PubMed]

46. Isaka, M.; Chinthanom, P.; Rachtawee, P.; Srichomthong, K.; Srikitikulchai, P.; Kongsaeree, P.; Prabpai, S. Cytotoxic hydroanthraquinones from the mangrove-derived fungus Paradictyoarthrinium diffractum BCC 8704. J. Antibiot. 2015, 68, 334-338. [CrossRef] [PubMed]

47. Wang, X.; Tan, T.; Mao, Z.G.; Lei, N.; Wang, Z.M.; Hu, B.; Chen, Z.Y.; She, Z.G.; Zhu, Y.H.; Wang, H.J. The marine metabolite SZ-685C induces apoptosis in primary human nonfunctioning pituitary adenoma cells by inhibition of the Akt pathway in vitro. Mar. Drugs 2015, 13, 1569-1580. [CrossRef] [PubMed]

48. Chen, C.H.; Xiao, W.W.; Jiang, X.B.; Wang, J.W.; Mao, Z.G.; Lei, N.; Fan, X.; Song, B.B.; Liao, C.X.; Wang, H.J.; et al. A novel marine drug, SZ-685C, induces apoptosis of MMQ pituitary tumor cells by downregulating miR-200c. Curr. Med. Chem. 2013, 20, 2145-2154. [CrossRef] [PubMed] 
49. Du, X.P.; Su, W.J. Two new polyketides from mangrove endophytic fungus Dothiorella sp. Chem. Nat. Compd. 2014, 50, 214-216. [CrossRef]

50. Pudhom, K.; Teerawatananond, T.; Chookpaiboon, S. Spirobisnaphthalenes from the mangrove-derived fungus Rhytidhysteron sp. AS21B. Mar. Drugs 2014, 12, 1271-1280. [CrossRef] [PubMed]

51. Wen, L.; Wei, Q.; Chen, G.; Cai, J.; She, Z. Chemical constituents from the mangrove endophytic fungus Sporothrix sp. Chem. Nat. Compd. 2013, 49, 137-140. [CrossRef]

52. Yan, H.J.; Li, X.M.; Li, C.S.; Wang, B.G. Alkaloid and anthraquinone derivatives produced by the marine-derived endophytic fungus Eurotium rubrum. Helv. Chim. Acta 2012, 95, 163-168. [CrossRef]

53. Ebrahim, W.; Kjer, J.; El Amrani, M.; Wray, V.; Lin, W.; Ebel, R.; Lai, D.; Proksch, P. Pullularins E and $\mathrm{F}$, two new peptides from the endophytic fungus Bionectria ochroleuca isolated from the mangrove plant Sonneratia caseolaris. Mar. Drugs 2012, 10, 1081-1091. [CrossRef] [PubMed]

54. Wu, Y.; Chen, S.; Liu, H.; Huang, X.; Liu, Y.; Tao, Y.; She, Z. Cytotoxic isocoumarin derivatives from the mangrove endophytic fungus Aspergillus sp. HN15-5D. Arch. Pharm. Res. 2018. [CrossRef] [PubMed]

55. Liu, D.; Li, X.M.; Li, C.S.; Wang, B.G. Nigerasterols A and B, antiproliferative sterols from the mangrove-derived endophytic fungus Aspergillus niger MA-132. Helv. Chim. Acta 2013, 96, 1055-1061. [CrossRef]

56. An, C.Y.; Li, X.M.; Luo, H.; Li, C.S.; Wang, M.H.; Xu, G.M.; Wang, B.G. 4-Phenyl-3,4-dihydroquinolone derivatives from Aspergillus nidulans MA-143, an endophytic fungus isolated from the mangrove plant Rhizophorastylosa. J. Nat. Prod. 2013, 76, 1896-1901. [CrossRef] [PubMed]

57. Deng, C.M.; Liu, S.X.; Huang, C.H.; Pang, J.Y.; Lin, Y.C. Secondary metabolites of a mangrove endophytic fungus Aspergillus terreus (No. GX7-3B) from the South China Sea. Mar. Drugs 2013, 11, 2616-2624. [CrossRef] [PubMed]

58. Deng, C.; Huang, C.; Wu, Q.; Pang, J.; Lin, Y. A new sesquiterpene from the mangrove endophytic fungus Aspergillus terreus (No. GX7-3B). Nat. Prod. Res. 2013, 27, 1882-1887. [CrossRef] [PubMed]

59. Qiu, L.; Wang, P.; Liao, G.; Zeng, Y.; Cai, C.; Kong, F.; Guo, Z.; Dai, H.; Mei, W.; Qiu, L.; et al. New eudesmane-type sesquiterpenoids from the mangrove-derived endophytic fungus Penicillium sp. J-54. Mar. Drugs 2018, 16, 108. [PubMed]

60. Zheng, C.J.; Liao, H.X.; Mei, R.Q.; Huang, G.L.; Yang, L.J.; Zhou, X.M.; Shao, T.M.; Chen, G.Y.; Wang, C.Y. Two new benzophenones and one new natural amide alkaloid isolated from a mangrove-derived Fungus Penicillium citrinum. Nat. Prod. Res. 2018. [CrossRef] [PubMed]

61. Xie, J.; Wu, Y.Y.; Zhang, T.Y.; Zhang, M.Y.; Zhu, W.W.; Gullen, E.A.; Wang, Z.J.; Cheng, Y.C.; Zhang, Y.X. New and bioactive natural products from an endophyte of Panax notoginseng. RSC Adv. 2017, 7, 38100-38109. [CrossRef]

62. Zhu, X.; Zhou, D.; Liang, F.; Wu, Z.; She, Z.; Li, C. Penochalasin K, a new unusual chaetoglobosin from the mangrove endophytic fungus Penicillium chrysogenum V11 and its effective semi-synthesis. Fitoterapia 2017, 123, 23-28. [CrossRef] [PubMed]

63. Zhu, M.; Yang, Z.; Feng, H.; Gan, Q.; Che, Q.; Zhu, T.; Gu, Q.; Han, B.; Li, D. Trichodermamides D-F, heterocyclic dipeptides with a highly functionalized 1,2-oxazadecaline core isolated from the endophytic fungus Penicillium janthinellum HDN13-309. RSC Adv. 2017, 7, 48019-48024. [CrossRef]

64. Huang, S.; Chen, H.; Li, W.; Zhu, X.; Ding, W.; Li, C. Bioactive chaetoglobosins from the mangrove endophytic fungus Penicillium chrysogenum. Mar. Drugs 2016, 14, 172. [CrossRef] [PubMed]

65. Meng, L.H.; Wang, C.Y.; Mandi, A.; Li, X.M.; Hu, X.Y.; Kassack, M.U.; Kurtan, T.; Wang, B.G. Three diketopiperazine alkaloids with spirocyclic skeletons and one bisthiodiketopiperazine derivative from the mangrove-derived endophytic fungus Penicillium brocae MA-231. Org. Lett. 2016, 18, 5304-5307. [CrossRef] [PubMed]

66. Meng, L.H.; Li, X.M.; Lv, C.T.; Huang, C.G.; Wang, B.G. Brocazines A-F, cytotoxic bisthiodiketopiperazine derivatives from Penicillium brocae MA-231, an endophytic fungus derived from the marine mangrove plant Avicenniam arina. J. Nat. Prod. 2014, 77, 1921-1927. [CrossRef] [PubMed]

67. Darsih, C.; Prachyawarakorn, V.; Wiyakrutta, S.; Mahidol, C.; Ruchirawat, S.; Kittakoop, P. Cytotoxic metabolites from the endophytic fungus Penicillium chermesinum: Discovery of a cysteine-targeted Michael acceptor as a pharmacophore for fragment-based drug discovery, bioconjugation and click reactions. RSC Adv. 2015, 5, 70595-70603. [CrossRef] 
68. Guo, W.; Li, D.; Peng, J.; Zhu, T.; Gu, Q.; Li, D. Penicitols A-C and Penixanacid A from the mangrove-derived Penicillium chrysogenum HDN11-24. J. Nat. Prod. 2015, 78, 306-310. [CrossRef] [PubMed]

69. Zheng, C.; Chen, Y.; Jiang, L.L.; Shi, X.M. Antiproliferative metabolites from the endophytic fungus Penicillium sp. FJ-1 isolated from a mangrove Avicennia marina. Phytochem. Lett. 2014, 10, $272-275$.

70. Zhou, Z.F.; Kurtan, T.; Yang, X.H.; Mandi, A.; Geng, M.Y.; Ye, B.P.; Taglialatela-Scafati, O.; Guo, Y.W. Penibruguieramine A, a novel pyrrolizidine alkaloid from the endophytic fungus Penicillium sp. GD6 associated with Chinese mangrove Bruguiera gymnorrhiza. Org. Lett. 2014, 16, 1390-1393. [CrossRef] [PubMed]

71. Li, J.; Yang, X.; Lin, Y.; Yuan, J.; Lu, Y.; Zhu, X.; Li, J.; Li, M.; Lin, Y.; He, J.; et al. Meroterpenes and azaphilones from marine mangrove endophytic fungus Penicillium 303\#. Fitoterapia 2014, 97, 241-246. [PubMed]

72. Yang, J.; Huang, R.; Qiu, S.X.; She, Z.; Lin, Y. A new isobenzofuranone from the mangrove endophytic fungus Penicillium sp. (ZH58). Nat. Prod. Res. 2013, 27, 1902-1905. [CrossRef] [PubMed]

73. Meng, L.H.; Li, X.M.; Lv, C.T.; Li, C.S.; Xu, G.M.; Huang, C.G.; Wang, B.G. Sulfur-containing cytotoxic curvularin macrolides from Penicillium sumatrense MA-92, a fungus obtained from the rhizosphere of the mangrove Lumnitzera racemose. J. Nat. Prod. 2013, 76, 2145-2149. [CrossRef] [PubMed]

74. Huang, Z.; Yang, J.; Cai, X.; She, Z.; Lin, Y. A new furanocoumarin from the mangrove endophytic fungus Penicillium sp. ZH16. Nat. Prod. Res. 2012, 26, 1291-1295. [CrossRef] [PubMed]

75. Zhang, L.; Niaz, S.I.; Khan, D.; Wang, Z.; Zhu, Y.; Zhou, H.; Lin, Y.; Li, J.; Liu, L. Induction of diverse bioactive secondary metabolites from the mangrove endophytic fungus Trichoderma sp. (Strain 307) by Co-Cultivation with Acinetobacter johnsonii (Strain B2). Mar. Drugs 2017, 15, 35. [CrossRef] [PubMed]

76. Zhang, L.; Niaz, S.I.; Wang, Z.; Zhu, Y.; Lin, Y.; Li, J.; Liu, L. $\alpha$-Glucosidase inhibitory and cytotoxic botryorhodines from mangrove endophytic fungus Trichoderma sp. 307. Nat. Prod. Res. 2017. [CrossRef] [PubMed]

77. Zhang, M.; Liu, J.M.; Zhao, J.L.; Li, N.; Chen, R.D.; Xie, K.B.; Zhang, W.J.; Feng, K.P.; Yan, Z.; Wang, N.; et al. Two new diterpenoids from the endophytic fungus Trichoderma sp. Xy24 isolated from mangrove plant Xylocarpus granatum. Chin. Chem. Lett. 2016, 27, 957-960. [CrossRef]

78. Shang, Z.; Li, X.M.; Li, C.S.; Wang, B.G. Diverse secondary metabolites produced by marine-derived fungus Nigrospora sp. MA75 on various vulture media. Chem. Biodivers. 2012, 9, 1338-1348. [CrossRef] [PubMed]

79. Tao, Y.W.; Lin, Y.C.; She, Z.G.; Lin, M.T.; Chen, P.X.; Zhang, J.Y. Anticancer activity and mechanism investigation of Beauvericin isolated from secondary metabolites of the mangrove endophytic fungi. Anticancer Agents Med. Chem. 2015, 15, 258-266. [CrossRef] [PubMed]

80. Zhang, J.; Lai, Z.; Huang, W.; Ling, H.; Lin, M.; Tang, S.; Liu, Y.; Tao, Y. Apicidin inhibited proliferation and invasion and induced apoptosis via mitochondrial pathway in non-small cell lung cancer glc-82 cells. Anticancer Agents Med. Chem. 2017, 17, 1374-1382. [CrossRef] [PubMed]

81. Huang, Z.J.; Guo, Z.Y.; Yang, R.Y.; She, Z.G.; Lin, Y.C. Alkaloid metabolites of mangrove endophytic fungus ZZF42 from the South China Sea. Zhong Yao Cai 2007, 30, 939-941. [PubMed]

82. Ding, L.; Dahse, H.M.; Hertweck, C. Cytotoxic alkaloids from Fusarium incarnatum associated with the mangrove tree Aegiceras corniculatum. J. Nat. Prod. 2012, 75, 617-621. [CrossRef] [PubMed]

83. Hemphill, C.F.P.; Daletos, G.; Hamacher, A.; Kassack, M.U.; Lin, W.; Mandi, A.; Kurtan, T.; Proksch, P. Absolute configuration and antitumor activity of torrubiellin B. Tetrahedron Lett. 2015, 56, 4430-4433. [CrossRef]

84. Hammerschmidt, L.; Debbab, A.; Ngoc, T.D.; Wray, V.; Hemphil, C.P.; Lin, W.H.; Broetz-Oesterhelt, H.; Kassack, M.U.; Proksch, P.; Aly, A.H. Polyketides from the mangrove-derived endophytic fungus Acremonium strictum. Tetrahedron Lett. 2014, 55, 3463-3468. [CrossRef]

85. Zeng, Y.B.; Gu, H.G.; Zuo, W.J.; Zhang, L.L.; Bai, H.J.; Guo, Z.K.; Proksch, P.; Mei, W.L.; Dai, H.F. Two new sesquiterpenoids from endophytic fungus J3 isolated from Mangrove Plant Ceriopstagal. Arch. Pharm. Res. 2015, 38, 673-676. [CrossRef] [PubMed]

86. Yang, J.X.; Qiu, S.X.; She, Z.G.; Lin, Y.C. Metabolites of mangrove endophytic fungus ZH-3 from South China Sea. Huagong Jishu Yu Kaifa 2014, 43, 1-3.

87. Yang, J.X.; Qiu, S.X.; She, Z.G.; Lin, Y.C. Metabolites of mangrove endophytic fungus 5094 from the South China Sea. Shizhen Guoyi Guoyao 2013, 24, 1059-1061.

88. Zhu, F.; Chen, G.Y.; Wu, J.S.; Pan, J.H. Structure revision and cytotoxic activity of marinamide and its methyl ester, novel alkaloids produced by co-cultures of two marine-derived mangrove endophytic fungi. Nat. Prod. Res. 2013, 27, 1960-1964. [CrossRef] [PubMed] 
89. Yang, J.X.; Qiu, S.X.; She, Z.G.; Lin, Y.C. Metabolites of mangrove endophytic fungus Gx-3a from the South China Sea. Guangxi Kexue 2013, 20, 168-170.

90. Yang, J.X.; Qiu, S.X.; She, Z.G.; Lin, Y.C. Metabolites of mangrove endophytic fungus SK7RN3G1 from South China Sea. Zhongguo Shiyan Fangjixue Zazhi 2012, 18, 95-98.

91. Choodej, S.; Teerawatananond, T.; Mitsunaga, T.; Pudhom, K. Chamigrane sesquiterpenes from a basidiomycetous endophytic fungus XG8D associated with Thai mangrove Xylocarpus granatum. Mar. Drugs 2016, 14, 132. [CrossRef] [PubMed]

92. Wibowo, M.; Prachyawarakorn, V.; Aree, T.; Mahidol, C.; Ruchirawat, S.; Kittakoop, P. Cytotoxic sesquiterpenes from the endophytic fungus Pseudolagarobasidium acaciicola. Phytochemstry 2016, 122, 126-138. [CrossRef] [PubMed]

93. Wibowo, M.; Prachyawarakorn, V.; Aree, T.; Wiyakrutta, S.; Mahidol, C.; Ruchirawat, S.; Kittakoop, P. Tricyclic and spirobicyclicnorsesquiterpenes from the endophytic fungus Pseudolagarobasidium acaciicola. Eur. J. Org. Chem. 2014, 19, 3976-3980. [CrossRef]

94. Gao, S.S.; Li, X.M.; Williams, K.; Proksch, P.; Ji, N.Y.; Wang, B.G. Rhizovarins A-F, indole-diterpenes from the mangrove-derived endophytic fungus Mucor irregularis QEN-189. J. Nat. Prod. 2016, 79, 2066-2074. [CrossRef] [PubMed]

95. Fenical, W.; Jensen, P.R.; Palladino, M.A.; Lam, K.S.; Lloyd, G.K.; Potts, B.C. Discovery and development of the anticancer agent salinosporamide A (NPI-0052). Bioorg. Med. Chem. 2009, 17, 2175-2180. [CrossRef] [PubMed]

96. Knight, V.; Sanglier, J.J.; DiTullio, D.; Braccili, S.; Bonner, P.; Waters, J.; Hughes, D.; Zhang, L. Diversifying microbial natural products for drug discovery. Appl. Microbiol. Biotechnol. 2003, 62, 446-458. [CrossRef] [PubMed]

97. Brakhage, A.A.; Schroeckh, V. Fungal secondary metabolites-strategies to activate silent gene clusters. Fungal Genet. Biol. 2011, 48, 15-22. [CrossRef] [PubMed]

98. Bode, H.B.; Bethe, B.; Höfs, R.; Zeeck, A. Big effects from small changes: Possible ways to explore nature's chemical diversity. ChemBioChem 2002, 3, 619-627. [CrossRef]

99. Cichewicz, R.H. Epigenome manipulation as a pathway to new natural product scaffolds and their congeners. Nat. Prod. Rep. 2010, 27, 11-22. [CrossRef] [PubMed]

100. Shwab, E.K.; Bok, J.W.; Tribus, M.; Galehr, J.; Graessle, S.; Keller, N.P. Histone deacetylase activity regulates chemical diversity in Aspergillus. Eukaryot. Cell 2007, 6, 1656-1664. [CrossRef] [PubMed]

101. Ola, A.R.B.; Thomy, D.; Lai, D.; Brötz-Oesterhelt, H.; Proksch, P. Inducing secondary metabolite production by the endophytic fungus Fusarium tricinctum through coculture with Bacillus subtilis. J. Nat. Prod. 2013, 76, 2094-2099. [CrossRef] [PubMed]

102. Zhu, F.; Chen, G.; Chen, X.; Huang, M.; Wan, X. Aspergicin, a new antibacterial alkaloid produced by mixed fermentation of two marine-derived mangrove epiphytic fungi. Chem. Nat. Compd. 2011, 47, 767-769. [CrossRef]

103. Li, C.; Zhang, J.; Shao, C.; Ding, W.; She, Z.; Lin, Y. A new xanthone derivative from the co-culture broth of two marine fungi (strain No. E33 and K38). Chem. Nat. Compd. 2011, 47, 382-384. [CrossRef]

104. Cueto, M.; Jensen, P.R.; Kauffman, C.; Fenical, W.; Lobkovsky, E.; Clardy, J. Pestalone, a new antibiotic produced by a marine fungus in response to bacterial challenge. J. Nat. Prod. 2001, 64, 1444-1446. [CrossRef] [PubMed]

105. Oh, D.C.; Jensen, P.R.; Kauffman, C.A.; Fenical, W. Libertellenones A-D: Induction of cytotoxic diterpenoid biosynthesis by marine microbial competition. Bioorg. Med. Chem. 2005, 13, 5267-5273. [CrossRef] [PubMed]

106. Park, H.B.; Kwon, H.C.; Lee, C.-H.; Yang, H.O. Glionitrin A, an antibiotic-antitumor metabolite derived from competitive interaction between abandoned mine microbes. J. Nat. Prod. 2009, 72, 248-252. [CrossRef] [PubMed]

107. Williams, R.B.; Henrikson, J.C.; Hoover, A.R.; Lee, A.E.; Cichewicz, R.H. Epigenetic remodeling of the fungal secondary metabolome. Org. Biomol. Chem. 2008, 6, 1895-1897. [CrossRef] [PubMed]

108. Asai, T.; Chung, Y.M.; Sakurai, H.; Ozeki, T.; Chang, F.R.; Yamashita, K.; Oshima, Y. Tenuipyrone, a novel skeletal polyketide from the entomopathogenic fungus, Isaria tenuipes, cultivated in the presence of epigenetic modifiers. Org. Lett. 2012, 14, 513-515. [CrossRef] [PubMed] 
109. Wang, X.; Filho, J.G.S.; Hoover, A.R.; King, J.B.; Ellis, T.K.; Powell, D.R.; Cichewicz, R.H. Chemical epigenetics alters the secondary metabolite composition of guttate excreted by an atlantic-florest-soil-derived Penicillium citreonigrum. J. Nat. Prod. 2010, 73, 942-948. [CrossRef] [PubMed]

110. Ul-Hassan, S.R.; Strobel, G.A.; Booth, E.; Knighton, B.; Floerchinger, C.; Sear, J. Modulation of volatile organic compound formation in the mycodiesel-producing endophyte Hypoxylon sp. CI-4. Microbiology 2012, 158, 465-473. [CrossRef] [PubMed]

111. Beau, J.; Mahid, N.; Burda, W.N.; Harrington, L.; Shaw, L.N.; Mutka, T.; Kyle, D.E.; Barisic, B.; Olphen, A.; Baker, B.J. Epigenetic tailoring for the production of anti-infective cytosporones from the marine fungus Leucostoma persoonii. Mar. Drugs 2012, 10, 762-774. [CrossRef] [PubMed]

2018 by the authors. Licensee MDPI, Basel, Switzerland. This article is an open access article distributed under the terms and conditions of the Creative Commons Attribution (CC BY) license (http://creativecommons.org/licenses/by/4.0/). 